\title{
Guyana: 2010 Article IV Consultation-Staff Report, Supplement, Public Information Notice on the Executive Board Discussion and Statement by the Executive Director for Guyana
}

Under Article IV of the IMF's Articles of Agreement, the IMF holds bilateral discussions with members, usually every year. In the context of the 2010 Article IV consultation with Guyana, the following documents have been released and are included in this package:

- $\quad$ The staff report for the 2010 Article IV consultation, prepared by a staff team of the IMF, following discussions that ended on November 18, 2010, with the officials of Guyana on economic developments and policies. Based on information available at the time of these discussions, the staff report was completed on January 5, 2011. The views expressed in the staff report are those of the staff team and do not necessarily reflect the views of the Executive Board of the IMF.

- $\quad$ A supplement on the Joint IMF/World Bank Debt Sustainability Analysis.

- $\quad$ A Public Information Notice (PIN) summarizing the views of the Executive Board as expressed during its February 16, 2011 discussion of the staff report that concluded the Article IV consultation.

- A statement by the Executive Director for Guyana.

The policy of publication of staff reports and other documents allows for the deletion of market-sensitive information.

\author{
Copies of this report are available to the public from \\ International Monetary Fund • Publication Services \\ $70019^{\text {th }}$ Street, N.W. • Washington, D.C. 20431 \\ Telephone: (202) 623-7430 • Telefax: (202) 623-7201 \\ E-mail: publications@imf.org Internet: http://www.imf.org
}

\section{International Monetary Fund Washington, D.C.}


INTERNATIONAL MONETARY FUND

GUYANA

\title{
Staff Report for the 2010 Article IV Consultation
}

\author{
Prepared by the Staff Representatives for the 2010 Consultation with Guyana \\ (In consultation with other departments)
}

Approved by Gilbert Terrier and Dhaneshwar Ghura

January 5, 2011

- Context. President Jagdeo is in his final term in office, and general elections are due in 2011. Guyana has become a magnet for environmental issues, given its large forestry reserves. In this context, its prospects hinge in part on a Low Carbon Development Strategy (LCDS) for structural transformation. The macroeconomic outlook is generally positive. On the downside, risks include global uncertainty, weak public enterprises especially the sugar company, delays in grant disbursements, and a widening external current account deficit. The authorities will need to pay careful attention to balancing infrastructural needs with fiscal and debt sustainability.

- Focus of the consultation. Discussions focused on a strategy for maintaining fiscal and debt sustainability over the medium term. Staff encouraged the authorities to lock in the gains from recent debt relief and fiscal consolidation, and recommended maintaining a strong fiscal stance and addressing public enterprise weaknesses. Staff welcomed the LCDS as an overall framework for transformation and cautioned against the contingent fiscal liabilities associated with the large Amaila Falls project. While welcoming ongoing regulatory reforms, staff urged sustained vigilance in monitoring financial sector risks, given the ongoing housing boom. Discussions also covered policies to enhance economic flexibility and resilience to shocks, while reducing poverty. The authorities broadly agreed with these recommendations.

- Exchange rate system. Guyana's de jure exchange rate regime is floating and the Fund has classified the de facto regime as a stabilized arrangement. There have been no changes in the exchange system and the related legal framework since the last Article IV Consultation.

- Mission. The team, comprising Therese Turner-Jones (Head), Garth P. Nicholls, Daniel Rodríguez-Delgado (all WHD), and Carlos Janada (FIN), visited Guyana during November 8-18, 2010. Leslie-Ann Des Vignes, (OED, Senior Advisor) and Calvin Djiofack (World Bank) also participated in the discussions. The team met with President Jagdeo, Prime Minister Hinds, Minister of Finance Ashni Singh, Central Bank Governor Lawrence Williams, representatives of the private sector, labor, and the donor community, and members of the political opposition. 


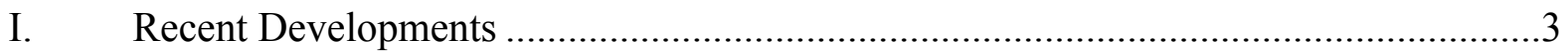

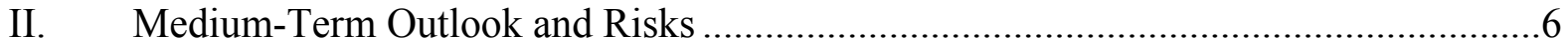

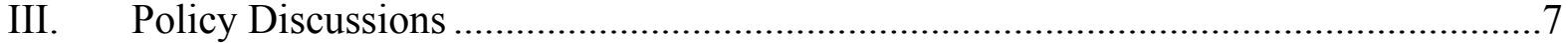

A. Policy Framework to Contain Fiscal Risks and Protect Debt Sustainability...........8

B. A Framework to Anchor Prices and Protect Financial Stability ...........................11

C. Agenda for Supporting Sustainable Growth and Poverty Reduction ....................12

D. Measures to Improve Official Data......................................................................15

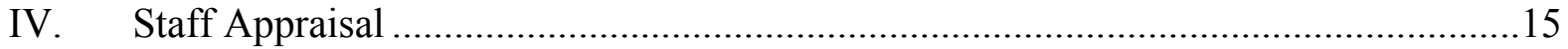

Boxes

1. The Impact of Higher Oil Prices in Guyana .........................................................4

2. Key Policy Recommendations of the 2009 Article IV Consultation ............................6

3. Exchange Rate Assessment................................................................................ 13

Figures

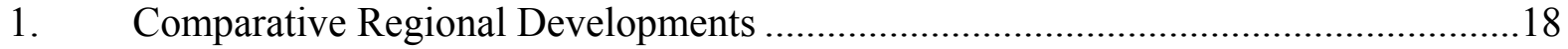

2. Real Sector Indicators .................................................................................... 19

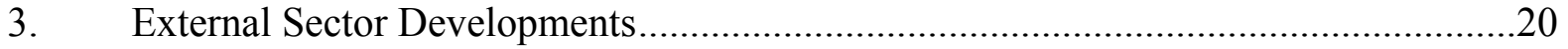

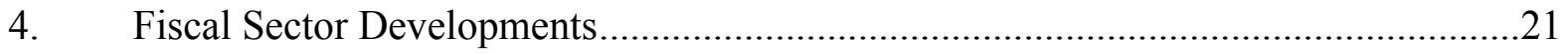

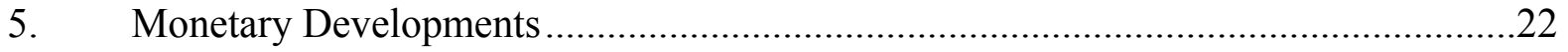

Tables

1. Selected Social and Economic Indicators ........................................................23

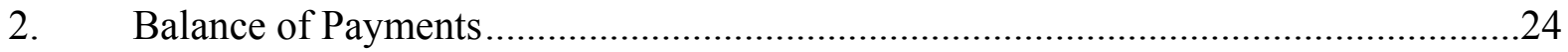

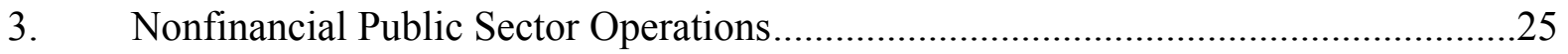

4. Summary Account of the Bank of Guyana and Monetary Survey ............................26

5. External Financing Requirements and Sources .................................................27

6. Indicators of External and Financial Vulnerability ............................................28

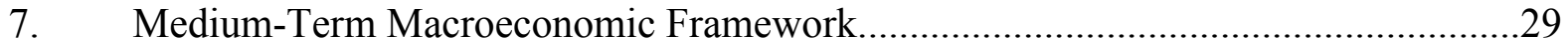

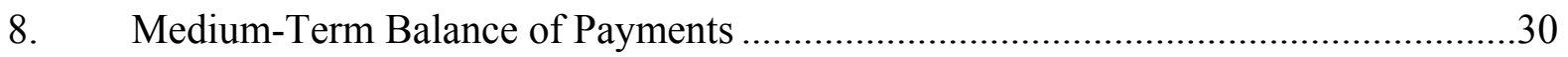

Attachments

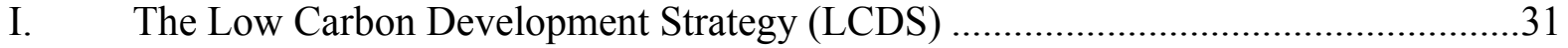

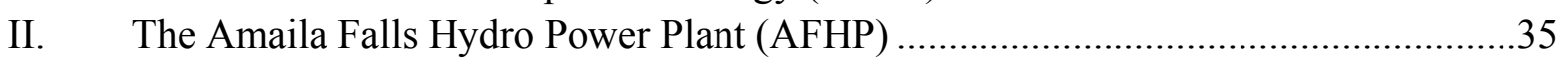

III. Sustainability of the National Insurance Scheme …................................................

IV. Financial Sector Stability and Reforms - Progress Since the FSAP .......................42 


\section{RECENT DEVELOPMENTS}

\section{Despite external and domestic shocks, in 2010 the Guyanese economy demonstrated resilience and registered a fifth consecutive year of robust growth.}

- $\quad$ Real output is estimated to have grown by around $3 \frac{1}{2}$ percent in 2010 . This performance, which is below that envisaged in the 2010 budget ( $4 \frac{1}{2}$ percent) and higher than the outturn in 2009, reflected strength in the gold and services sectors. The sugar sector continued to be hampered by labor shortages and factory problems. Inflation is estimated to have picked up to 4.4 percent at year-end, from 3.7 percent in 2009 , due to hikes in food prices.

\section{- $\quad$ Albeit fully financed, the external current account deficit has widened. Despite} higher exports (bauxite, gold) and rising remittances, the current account deficit is estimated to have widened from 8.8 percent of GDP in 2009 to 11.4 percent in 2010, driven by lower sugar prices and higher fuel costs (Box 1). ${ }^{1}$ In the capital account, private inflows moderated, but steady public external financing helped keep gross reserves at the equivalent of about five months of imports at end-2010.

\section{- In 2010, the public finances} weakened somewhat. The nonfinancial public sector (NFPS) deficit is estimated to have reached 4.3 percent of GDPexceeding the budget deficit target of 3.2 percent of GDP, and up from 3.4 percent in 2009. Notwithstanding strong tax revenues, the performance of public enterprises (particularly GUYSUCO) has been weak and the disbursement of grants has slowed. In addition, there is a risk that, if some grant disbursements ( 0.9 percent of GDP) do not materialize by year-end, the deficit could reach 5.2 percent of GDP. The authorities are exploring financing options, including the use of existing PetroCaribe savings. $^{2}$

\footnotetext{
${ }^{1}$ Although Guyana no longer benefits from preferential prices in the European market, transitional arrangements are in place until September 2015.

2 This is a contingency plan, in the event that the grants are not be disbursed by end-December 2010, as envisaged by the authorities. At end-September 2010, the accumulated PetroCaribe savings amounted to about 5 percent of GDP. These funds (US\$108 million) are held abroad.
} 


\section{Box 1. The Impact of Higher Oil Prices in Guyana}

The Guyanese economy is particularly exposed to oil price movements, as it relies exclusively on imports for its oil consumption. In 2010, oil-related imports represented some 16 percent of GDP and were a main driver in the widening of the external current account deficit. Part of these imports (4 percent of GDP) is required for electricity generation by the public electricity company Guyana Power \& Light (GPL), which uses antiquated, energy intensive processes.

Changes in oil prices have a significant impact on the fiscal accounts. First, as GPL relies on fuel imports to generate electricity, a 10 percent increase in oil prices is associated with deterioration in its operational balance of about 0.4 percentage points of GDP (assuming that electricity prices are left unchanged). Second, tax revenue is affected through the ad-valorem excise tax on fuel sales. In recent years, the government has lowered the tax to counteract the effect of oil price increases. ${ }^{1}$ Under the assumption that changes in the excise tax absorb half of any given increase, a 10 percent rise in world oil prices boosts tax revenue by 0.6 percentage points of GDP.

The external current account balance is vulnerable to oil price shocks. Oil price shocks are mostly reflected in the fuel import bill, with a minor effect also on non factor services. A 10 percent increase in oil prices widens the current account deficit by $1 \frac{1 / 4}{4}$ percentage points of GDP. This deterioration is almost fully transmitted to the overall balance, notwithstanding the access to PetroCaribe financing, as the authorities have been saving most of these resources abroad.

${ }^{1}$ This measure is temporary. A central role of the Low Carbon Development Strategy is to enable a structural transformation, thus lowering exposure to oil prices. Further, as oil prices are projected to stabilize over the medium term and Guyana's dependence on oil would lessen as it switches to hydroelectricity, this type of price mechanism would play a lesser role. Staff will review this mechanism with the authorities in future discussions.

- Monetary policy was moderately expansionary. Twelve-month broad money growth-the anchor of monetary policy - and credit to the private sector were robust, at 10 percent and 11.6 percent respectively in September 2010. Treasurybill rates have fallen below inflation, which has been relatively subdued. The currency has remained broadly stable against the U.S. dollar, in the context of a steady increase in reserves. Most financial system indicators improved markedly through end-September 2010, including the NPL ratio which has declined to 6 percent of total loans.
Financial Soundness Indicators, 2005-10 (In percent)

\begin{tabular}{lrrrrrr}
\hline & 2005 & 2006 & 2007 & 2008 & 2009 & $2010 \mathrm{Q} 3$ \\
\hline Capital to risk-adjusted assets & 14.4 & 15.5 & 15.0 & 14.9 & 18.3 & 18.8 \\
NPLs to total loans & 13.9 & 11.6 & 10.7 & 9.5 & 8.3 & 6.0 \\
Provision for loan loss to NPLs & 44.4 & 41.0 & 54.2 & 49.3 & 53.8 & 75.0 \\
Return on assets & 1.9 & 2.3 & 2.4 & 2.3 & 2.7 & 3.0 \\
Return on equity & 23.1 & 27.7 & 27.6 & 25.2 & 26.6 & 28.9 \\
Liquid assets to total assets & 32.5 & 33.0 & 26.5 & 29.8 & 30.9 & 26.4 \\
Related party loans to total loans & 5.0 & 3.8 & 3.7 & 4.5 & 4.5 & 3.8 \\
Top 20 borrowers to total loans & 44.5 & 44.4 & 39.2 & 33.2 & 35.5 & 29.8 \\
\hline
\end{tabular}

Sources: Guyanese authorities. 


\section{During 2010, reform efforts continued in the fiscal and financial sectors.}

- $\quad$ Fiscal Sector. Reforms at the Guyana Revenue Authority (GRA) have continued, including streamlining the new functional organization, further improvements in the integrated tax information system (TRIPS), profiling of tax payers and implementation of onsite inspections in the country's ports of entry, and more intensive training to personnel.

- $\quad$ Financial Sector. To support development of the credit market and improve lending conditions, the authorities passed the Credit Bureau Act, and guidelines for its operations are being prepared. In addition, legislation was passed in parliament bringing the mortgage institution New Building Society (NBS) under the supervision of the Bank of Guyana.

\section{Other reforms in 2010 were in support of long term growth.}

- Low Carbon Development Strategy (LCDS). The authorities shepherded the signing of a LCDS trusteeship agreement between Norway and the World Bank on the administration of a US\$250 million payment pledged to Guyana by Norway, paving the way for the annual disbursements to commence. A Multi-Stakeholder Steering Committee has been formed to oversee the selection of investment projects (Attachment I).

- $\quad$ Sugar Sector. Modernization plans continue with the reorientation of cane fields to better accommodate mechanization. Meanwhile, work also continued on the sugar packing plant, which is part of the overall strategy to improve revenue, and is expected to come on stream in early 2011.

- Infrastructure. During 2010 the authorities started a project to improve the distribution and transmission of electricity throughout Guyana. The Guyana Power and Light Company (GPL) is also installing additional generation capacity to replace worn out equipment and correct for longstanding underinvestment in generation capacity. In the area of information technology, a fiber-optic cable project linking Guyana and Brazil is being installed, which would facilitate the introduction of e-government. In the housing sector, additional external resources have been secured for the expansion of low income housing. Finally, work has commenced on the access road to the AFHP site, while enhancement work is soon to start on the road from Georgetown and the international airport.

- $\quad$ Poverty reduction. The authorities are currently preparing an outline of the Poverty Reduction Strategy Paper (PRSP) for discussion with the Cabinet Committee on Finance by July 2011. They are assessing the costs of achieving the MDGs with technical donor support. 
Box 2. Key Policy Recommendations of the 2009 Article IV Consultation

\section{Staff's advice centered on the need to:}

- $\quad$ Preserve the prudent policy framework to further entrench fiscal and debt sustainability;

- Maintain a cautious monetary policy stance to contain inflation;

- Carefully monitor asset quality and enhance prudential measures;

- $\quad$ Continue with the ongoing structural reforms to modernize the sugar sector and diversify Guyana's productive base, which are critical to sustaining long-term growth and alleviating poverty;

- $\quad$ Enhance data quality and dissemination and subscribe to the GDDS.

Authorities' views. While there was broad agreement on the need to preserve a prudent policy framework to further entrench fiscal and debt sustainability, the fiscal consolidation achieved in 2009 allowed for a somewhat more gradual pace for fiscal tightening in 2010-11. In their view, this would help accommodate priority infrastructure spending, and support growth.

\section{MEDIUM-TERM OUTLOOK AND RISKS}

\section{The baseline macroeconomic outlook remains positive for 2011, an election year,} and the medium term. Guyana is on the cusp of major changes, led by the government's Low Carbon Development Strategy (LCDS) and private sector investments in gold, oil, and gas sectors as well as the large PPP associated with the construction of hydroelectric plant AFHP (Attachment II). These investments should sustain growth levels above the long-run trend of 3 percent, to around 5 percent over the medium term. While fully financed, the external current account deficit would narrow somewhat in 2011-largely on account of receipts from the GRIF $^{3}$ — before widening in subsequent years as the AFHP is being constructed.

\begin{tabular}{|c|c|c|c|c|c|c|c|c|c|}
\hline \multicolumn{10}{|c|}{$\begin{array}{l}\text { Medium-Term Macroeconomic Framework } \\
\text { (In percent of GDP, unless specified otherwise) }\end{array}$} \\
\hline & \multirow[b]{2}{*}{2007} & \multirow[b]{2}{*}{2008} & \multirow[b]{2}{*}{2009} & \multicolumn{6}{|c|}{ Projections } \\
\hline & & & & 2010 & 2011 & 2012 & 2013 & 2014 & 2015 \\
\hline Real GDP (in percent) & 7.0 & 2.0 & 3.3 & 3.4 & 4.8 & 6.0 & 6.1 & 5.0 & 2.7 \\
\hline o/w sugar sector & 2.7 & -15.1 & 3.3 & -1.6 & 31.7 & 7.3 & 4.8 & 6.0 & 4.5 \\
\hline o/w non-sugar sector & 7.2 & 3.4 & 3.0 & 3.8 & 3.2 & 5.7 & 6.1 & 4.8 & 2.5 \\
\hline Inflation (end of period) & 14.0 & 6.4 & 3.7 & 4.4 & 4.4 & 5.4 & 5.4 & 5.4 & 5.4 \\
\hline Overall fiscal balance & -4.9 & -4.7 & -3.4 & -4.3 & -3.5 & -3.2 & -3.1 & -3.0 & -3.0 \\
\hline External current account balance & -11.1 & -13.2 & -8.8 & -11.4 & -8.8 & -18.6 & -18.5 & -16.5 & -9.2 \\
\hline NPV of public debt-to-GDP ratio (in percent) & 42 & 41 & 48 & 48 & 48 & 47 & 47 & 48 & 48 \\
\hline NPV of public debt-to-revenue ratio (in percent) 1/ & 152 & 159 & 170 & 180 & 158 & 161 & 168 & 174 & 174 \\
\hline Gross official reserves (in US\$ millions) & 312.6 & 355.9 & 627.5 & 664.3 & 776.7 & 869.5 & 889.3 & 855.5 & 901.4 \\
\hline In months of imports & 2.9 & 2.7 & 5.1 & 4.8 & 5.1 & 4.9 & 4.8 & 4.4 & 4.9 \\
\hline
\end{tabular}

Sources: Ministry of Finance; and Fund staff estimates and projections.

1/ Revenue including grants.

\footnotetext{
${ }^{3}$ Guyana's Reducing Emissions and Deforestation Investment Fund (GRIF) supported by Norway.
} 
5. Risks remain, but are more balanced over the longer term. On the upside, Guyana stands to gain from the global carbon credit market on account of its large rainforests, and the implementation of the LCDS. While gold and sugar prices are at historical highs, Guyana will also benefit over time from lower electricity prices. Downside risks include those linked to a potential overheating in the economy, volatile commodity prices, fiscal pressures from weak public enterprises (GUYSUCO, GPL, and the National Insurance Scheme), and some aid volatility. Finally, the sustained large current account deficit may also become a source of risk.

\section{Policy Discussions}

6. Discussions took place against the backdrop of favorable economic performance and prospects, while the authorities confront complex decisions requiring careful preparation. Thus, the focus was on establishing:

- A Policy Framework to Contain Fiscal Risks and Protect Debt Sustainability. While the LCDS is viewed as a platform for transforming the economy, it is a long term process. Immediate needs include minimizing the fiscal impact from underperforming public enterprises, volatile aid commitments, and rising oil prices. Focusing on a strategy for maintaining fiscal and debt sustainability over the medium term is critical, as well as considering how Guyana can best cope with the impact of its incipient oil and gas exploitation. ${ }^{4}$

- $\quad$ A Framework to Anchor Prices and Protect Financial Stability. Keeping inflation relatively low and maintaining vigilance over the financial system remain important features of macroeconomic policy to guarantee stability.

- $\quad$ An Agenda for Supporting Sustainable Growth and Poverty Reduction. Enhancing the performance of public enterprises, minimizing exposure to risks in the context of upcoming PPPs, measures to lock in gains from natural resource development and expanding economic opportunities from the LCDS are all key to sustaining long-term growth and reducing poverty. The impact of the Amaila Falls project will need to be carefully monitored, during the construction (end-2011-14) as well as at the operational stages (2015 onward) to ensure that the economic benefits materialize as expected, especially on energy costs and GPL's balance sheet.

\footnotetext{
${ }^{4}$ Several companies, including CGX and Repsol, are moving ahead with exploration. Some private estimates place potential oil reserves at 15.2 billion barrels, consistent with production of 50 million barrels a year.
} 


\section{A. Policy Framework to Contain Fiscal Risks and Protect Debt Sustainability}

\section{Fiscal Policies}

7. The authorities view fiscal consolidation as a priority in 2011 and over the medium term to protect debt sustainability. Despite some easing in 2010, the 2011 budget and medium term plans envisage a tightening of the fiscal stance. The path would lower the NFPS deficit to around 3.5 percent of GDP in 2011-12, and gradually converge to a deficit of 2.5 percent of GDP by 2030 . This stance would ensure consistency with a reduction in the debt-to-GDP ratio, while

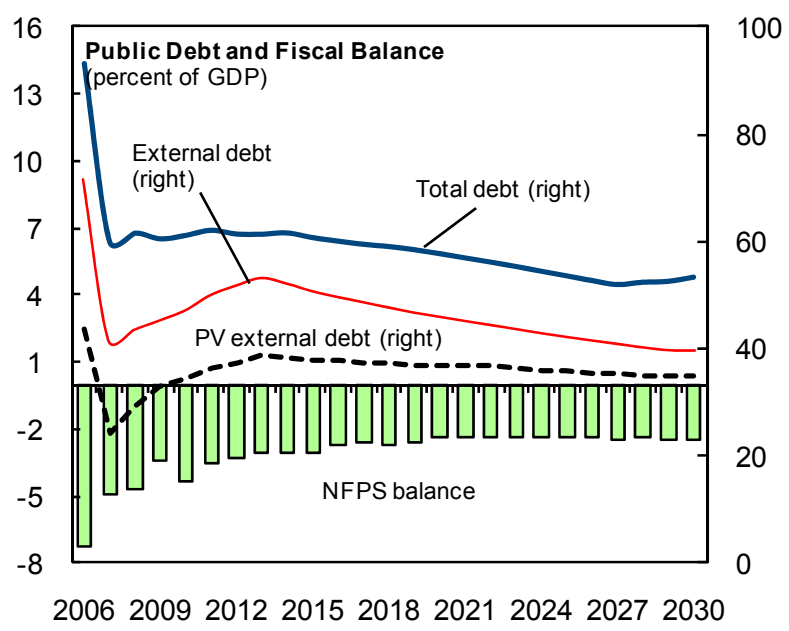
leaving room for some flexibility as needed.

8. Staff agreed that maintaining a strong fiscal stance was critical, given lingering underperformance in public enterprises and unstable grant inflows. Acknowledging slippage from the budget target in 2010 , the authorities were committed to protecting debt sustainability and resuming consolidation along the lines agreed at the time of the last Article IV consultation, although at a slightly slower pace. They pointed to continued improvements in public financial management - especially revenue administration - as well as efforts to bolster the financial position of the National Insurance System (NIS) as key to attaining their fiscal targets (Attachment III). They also agreed that achieving these objectives may require restraining the pace of spending growth. The authorities noted that the timing of grant disbursements had complicated budget planning, adding a degree of uncertainty to budget execution. Meanwhile, they viewed their accumulated PetroCaribe savings as a buffer to smooth out grant shortfalls. ${ }^{5}$ In view of Guyana's risk of moderate debt distress, staff cautioned that contingency plans be in place in the event that weaknesses in public enterprises, or shortfalls in aid commitments jeopardize attainment of the 2011 deficit target of 3.5 percent of GDP. ${ }^{6}$

\section{Staff cautioned that a mismatch between pension benefits and contributions} threaten the sustainability of the Social Security Scheme (NIS). Projections show that, after 2011, NIS will shift from small surpluses to growing deficits, largely as a result of rising benefit payments. The finances of NIS remain plagued by contribution arrears and evasion by both workers and employers. An additional challenge is the large investment of

\footnotetext{
${ }^{5}$ See footnote 2 .

${ }^{6}$ This assessment, which is unchanged from that in the 2009 Article IV Consultation, is linked to the stress tests on debt service (see Guyana-Joint IMF-World Bank Debt Sustainability Analysis).
} 
18.6 percent of total assets, or 1.3 percent of GDP that the NIS has in the CLICO conglomerate, ${ }^{7}$ for which the government has extended a guarantee. The authorities have established a reform committee to provide guidelines on the way forward. Although, many of these recommendations have not been implemented, the NIS has begun to intensify monitoring in a few areas, to ensure that beneficiaries meet qualifying conditions, and by establishing compliance certificates for businesses. More actions would, however, be required to restore its medium term financial viability.

\section{The operating surplus of public enterprises is projected to rise from 0.6 percent of GDP in 2010 to 1.9 percent in 2011, supported by an expected surge in sugar production.}

- $\quad \boldsymbol{G U Y S U C O}$. The authorities estimate that GUYSUCO's sugar production will rise by about one third in 2011, to 300,000 tons. Staff noted that, despite the major capital injection in this company, this outturn would require significant improvements in labor productivity and the resolution of existing technical problems at the Skeldon plant. ${ }^{8}$ The authorities expressed confidence that existing issues would be resolved in the near future, as they were actively engaged with all parties in boosting output, to get the full benefits of significantly higher world sugar prices.

- $\quad \boldsymbol{G P L}$. Prospects are expected to improve significantly over the medium term, once the AFHP becomes operational (in the near term, it could have a moderate negative impact on GPL's accounts). Under this project, AHFP will have the capacity to generate electricity output far in excess of present demand, which should enable a significant reduction in the electrical tariff rates charged by GPL (Attachment II). In turn, its electricity sales would rise sharply, as self-generators would be attracted to the lower rates charged by GPL. Staff cautioned that, while a strong increase in the customer base might be feasible, weak administrative capacity, still-limited solvent demand, and limited delivery infrastructure could prevent GPL from reaching the full benefits of the project. ${ }^{9}$ As a result, its profitability could be lower than expected, adversely affecting the overall fiscal balance.

\footnotetext{
${ }^{7}$ CLICO (Guyana) is under judicial management and the government expects to realize proceeds from the sale of fixed assets which will be used to compensate NIS and other investors.

${ }^{8}$ Additional lands under cultivation, mechanization, boiler replacement and shift in harvesting cane from 2010 to 2011 should boost production.

${ }^{9}$ Additional risks include GPL's inability to generate sufficient revenue to cover the guaranteed payments and the new plant's electricity output falling short of expectations. GPL's projections provide some assurances against the former. In the latter case, if the private partner was unable to deliver enough energy (for reasons other than hydrological factors) GPL will need to resort to its oil-dependent energy plants to cover the gap; in this case, the contractor will reimburse GPL for these operational costs.
} 
- Government's guarantee to NIS. The NIS is unlikely to be fully covered by the CLICO payout strategy, mostly financed by the Caribbean Petroleum Fund of US\$15 million, with the remainder expected from judicial action and asset recovery. Without full recovery of these investments and near term reforms to restore financial viability at the NIS, government's guarantee would be called as the CLICO investments mature, ${ }^{10}$ potentially increasing public debt by up to1.3 percent of GDP.

11. While Guyana's level of debt distress remains moderate, staff emphasized the need to keep the debt trajectory on a downward path. The authorities considered that their current strategy of using medium term debt sustainability as a fiscal anchor continues to be appropriate. Public debt ratios are projected to decrease moderately to around 60 percent of GDP over the medium term, and further to around 53 percent by $2030 .{ }^{11}$ The external debt sustainability analysis (DSA) indicates that risks to external stability remain moderate. The PV of external public debt is expected to remain just under the DSA benchmark of 40 percent of GDP, while all other sustainability indicators are well below their respective thresholds. Over the medium term, FDI would cover some 80 percent of the current account deficit and projected PSIP inflows, protecting the foreign reserve coverage at about 5 months of imports. External debt service would remain comfortable at the equivalent of 4-5 percent of exports and 6-9 percent of government revenue, respectively. Downside risks include lower-than envisaged grants and FDI inflows in the aftermath of the global crisis. ${ }^{12}$ Staff also emphasized the need for Guyana to keep seeking access to high concessional terms to protect debt sustainability.

\footnotetext{
${ }^{10}$ The CLICO investment is due to mature in a few years.

${ }^{11}$ Net public debt excludes PetroCaribe disbursements that are saved in an escrow account. In the baseline scenario, these deposits are assumed to rise hand-in-hand with larger PetroCaribe disbursements, as world fuel prices increase over the medium term - following past practice by the Guyanese authorities.

${ }^{12}$ The authorities adjust expenditures to match available grants. This is done in two stages, initially during budget preparation, an assessment is made of potential grants during the year. Then during the year, expenditure plans are adjusted based on the realization of grants.
} 

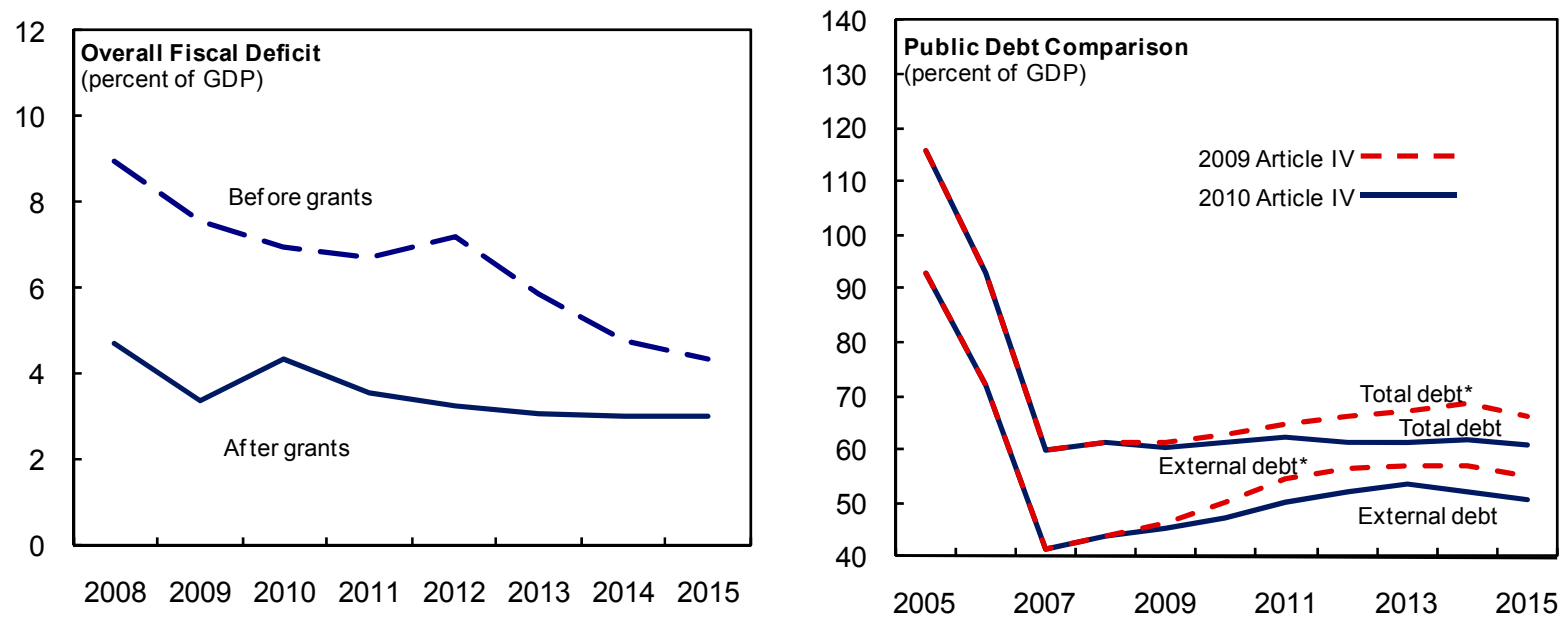

\section{B. A Framework to Anchor Prices and Protect Financial Stability}

\section{Monetary and Exchange Rate Policies}

12. The monetary stance remains supportive of macroeconomic stability. Staff noted that while inflation is currently low, the authorities should stand ready to prevent any build up of inflationary pressures. The authorities planned to continue conducting monetary policy through open market operations (OMO) and stressed their willingness to tighten monetary policy, should price pressures develop. Staff cautioned that success in this strategy would, however, also be dependent on the degree of exchange rate flexibility, as this would determine the ability of the BOG to use foreign exchange sales to reduce liquidity in support of OMO, and further noted that the managed float also removed the exchange rate appreciation channel for containing inflationary pressures.

\section{Staff stressed that while financial sector risks appear contained, the need for} continued financial sector vigilance remains. Data through end-September 2010 suggest that most financial system indicators, including NPL and provisioning ratios, have improved considerably since last year. These improvements mostly reflect improved economic conditions as well as enhanced risk management on the part of banks. Further, the authorities have successfully implemented most of their planned financial sector reforms (Attachment IV). In recent years, however, a construction boom has developed, facilitated in part by the authorities' adoption, since 2009, of the second phase of their mortgage program, based on tax and reserve requirement exemptions. ${ }^{13}$ Staff cautioned that there was a need to monitor such credit growth closely, to avoid developing excessive exposures in households'

\footnotetext{
${ }^{13}$ The Government's low income housing initiative was originally launched in 1992 as part of a land divestiture process funded by the IDB. The second phase of the program, also funded by the IDB began in 2009. Under this phase, in addition to tax and reserve requirement exemptions on mortgages to low-income earners, each bank's limit was raised from G\$3 million to G\$8 million, not only the New Building Society’s.
} 
balance sheets. However, the authorities were of the view that, given high liquidity in the system, the housing deficit, and the unmet demand for housing in the society, the demand for private sector credit needed to be accommodated.

\section{Staff welcomed legislative improvements in the regulation of the non-bank} financial sector. The recent passage of legislation to bring the mortgage institution NBS under direct central bank supervision is notable, and staff was encouraged by the authorities' efforts to do the same for credit unions. In addition, work on developing a credit bureau is in advanced stages which would go a long way in reducing intermediation costs for borrowers. Staff welcomed the dissemination of financial sector indicators, which now appear on the Bank's website.

15. Staff reiterated its view that greater exchange rate flexibility would provide a useful buffer against external shocks when warranted. While in the recent period exchange rate stability has been supported by adequate inflows of foreign exchange, large swings in commodity prices, especially oil, can pose external risks. In this regard, greater exchange rate flexibility could, by limiting Bank of Guyana interventions in the foreign exchange market to smoothing episodes of excessive volatility, provide a useful policy tool to help preserve macroeconomic stability. The authorities, however, maintained that their exchange rate arrangement has served them well in the past and noted their preference for exchange rate stability. They also noted that they have resisted systematic interventions in the foreign exchange market to influence the exchange rate path. In real effective terms, Guyana's currency is assessed to be moderately above its equilibrium level, while broadly consistent with external stability (Box 3).

\section{Agenda for Supporting Sustainable Growth and Poverty Reduction}

\section{Staff emphasized that, while the process of modernization of the sugar sector} remains critical to growth, it has been protracted in recent years. ${ }^{14}$ Sugar production continues to play a key role in Guyana, as a major contributor to both foreign exchange earnings and employment. Despite large investments at GUYSUCO's Skeldon plant and

\footnotetext{
${ }^{14}$ The sugar sector difficulties are longstanding. Following a period of nationalization from 1971 to 1990 , GUYSUCO was placed under a management contract with a multinational sugar company, Booker Tate. However, costs have remained high relative to other international producers, and the industry suffered falling output and significant financial losses from 2005-09. In March 2009, the Booker Tate management contract was discontinued and the government appointed a board to restructure the industry and increase its competitiveness. A key component of the plan involved increasing cane production, including through outsourcing to private farmers. Meanwhile, the factory at Skeldon has remained only partly functional. The industry is characterized by: (a) an influential, unionized labor force employed in field operations; and (b) a legacy of social responsibilities, as it provides key social services (health and education) and jobs to many communities. In light of these factors, restructuring the industry involves changes in the way of life for a sizeable proportion of rural Guyana and, as a result, the process has been slow and difficult.
} 


\section{Box 3. Guyana: Exchange Rate Assessment}

During 2010 Guyana's currency depreciated in real terms, interrupting an appreciation trend. After having registered an appreciation of around 15 percent during 2004-09, the real effective exchange rate (REER) fell by 3.7 percent during the first ten months of 2010. These movements largely reflected developments in the value of the U.S. dollar (which the Guyanese dollar follows closely) against the Euro and other major currencies. ${ }^{1}$

\section{CGER-type of analysis suggests that the} Guyanese currency is moderately above its equilibrium level. Staff used the external sustainability (ES) and macroeconomic balance (MB) approaches to assess external stability in Guyana. ${ }^{2}$ The ES approach suggests that the REER is 9.5 percent above the level that would stabilize the net foreign asset (NFA) position at its 2010 level, while the MB approach suggests that the REER is 11.5 percent above the level necessary to bring the projected external current account balance (9 percent of GDP) down to its norm level (5.3 percent of GDP) over the medium term.

\section{This assessment reflects somewhat} higher deviations from equilibrium than
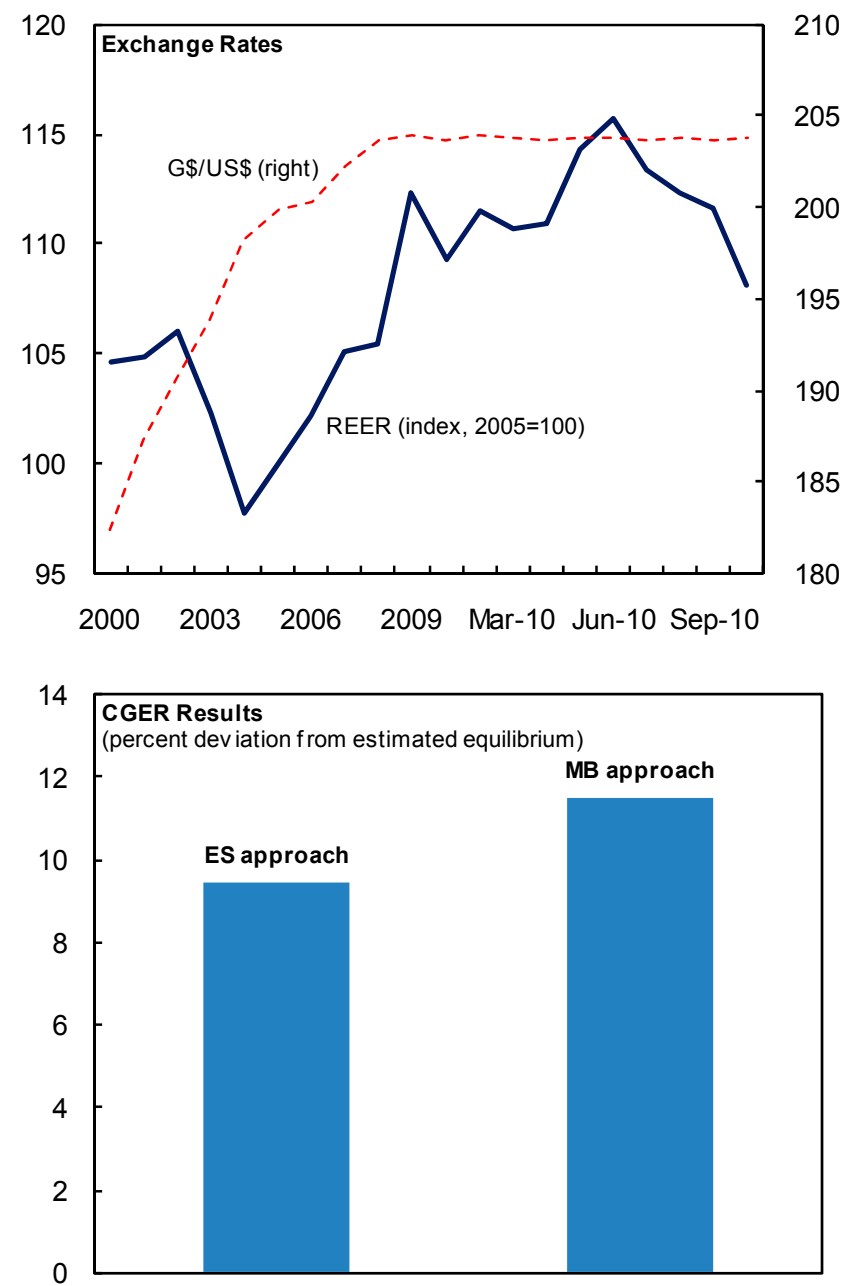
in the 2009 Article IV consultation. The differences are mostly driven by a wider current account deficit over the medium term, in line with imports of capital goods associated with large infrastructure projects. Beyond the medium term, both the fuel import savings due to the AFHP and some export strengthening would allow a gradual narrowing of the deficit.

${ }^{1}$ Guyana's exchange rate regime is a stabilized arrangement, according to the most recent Fund classification.

${ }^{2}$ The equilibrium real exchange rate could not be estimated due to the lack of data on productivity indicators.

attempts at further mechanizing production and expanding acreage, sugar output has continued to disappoint. Multiple factors explain this performance, ranging from malfunctioning equipment, adverse weather conditions, labor shortages, and management problems. Although the authorities are seeking to rectify these problems promptly, labor shortages, mainly from competing opportunities in construction and other agriculture are 
hampering production. ${ }^{15}$ In that context, staff suggested ramping up mechanization plans while continuing to engage workers toward resolving the ongoing issues.

\section{Staff and the authorities agreed that pro-environmental policies could support} growth and reduce vulnerabilities. Pressing ahead with the LCDS, aimed at transforming the economy while preserving the environment, is now well entrenched in public policy. The LCDS seeks to ensure a steady carbon-credit flow over the long-term in exchange for forest preservation. Under the strategy, the authorities aim to channel resources obtained from global partners - initially Norway - to target specific economic areas. Successful implementation of the LCDS will re-position the Guyanese economy to better compete on a global scale and unleash opportunities for reducing poverty. The agreement with Norway will provide up to US\$250 million in payments for forest services over five years, with the IDB as the main implementing partner, paving the way for disbursements to begin early 2011. ${ }^{16}$ As such, these resources would be governed by the relatively strong PFM framework ${ }^{17}$ currently operational in Guyana. Given that Guyana is the first country in the world to develop such a partnership on the environment, it stands to benefit from global attention but also will be subject to international scrutiny as the strategy is being implemented.

\section{Staff urged the authorities to put appropriate measures in place to safeguard against fiscal risks as individual projects move ahead, in particular Amaila Falls.}

- $\quad$ Private sector interest in Guyana's gold, other mining, oil, and gas sectors is encouraging, with some projects likely to come on stream over the near to medium term. In the interim, Guyana will prepare a plan on how best to manage its natural resources, with a view to coping with potential Dutch disease and other overheating pressures. Staff suggested that this plan include standard protocols for taxation as well as consideration of the creation of a stabilization fund. ${ }^{18}$

- With respect to the Amaila Falls project, expected to start in late 2011, staff welcomed the high level of transparency and public disclosure of the project to date, including reflecting any firm or contingent liabilities from PPPs in debt statistics, as they relate to best practices of transparency in fiscal accounting of PPPs. Staff cautioned that

\footnotetext{
${ }^{15}$ The industry reports that worker turnout is only around 52 percent of the workforce.

${ }^{16}$ The World Bank is Trustee for the funds, the GRIF.

${ }^{17}$ Guyana's CPIA cluster averaged 3.1 or in the middle range for PFM for last four years. However their existing PEFA action identified over half of needed actions already completed. Notable among which for this purpose is action on government's procurement systems (use of manuals and guidelines) which are being enhanced with the use of management IT systems and being developed in conjunction with a development partner.

${ }^{18}$ Trinidad and Tobago's Heritage Fund was highlighted as an example as well as Norway's.
} 
while energy costs could be significantly reduced once the project becomes operational in 2015, details of the PPP should be carefully assessed to safeguard against sovereign risks in such a large project (30 percent of GDP). Staff reiterated earlier advice on the use of international best practices in projects of this nature to which the authorities fully agreed (see Attachment II).

\section{Staff welcomed the authorities' plans to press ahead with the preparation of the} revised PRSP. This will include an MDG costing exercise prepared with technical assistance from donors. Staff also noted the authorities' plan to put in place adequate monitoring and evaluation mechanisms to support its implementation, along with defining a tentative calendar for its release. Staff encouraged the authorities to continue its dialogue with all stakeholders (labor, civil society, and political parties) as this exercise is crucial for building national consensus on Guyana's economic agenda.

\section{Measures to Improve Official Data}

20. The quality of statistics is improving, but data provision needs further strengthening. In early 2010, the authorities released rebased GDP and revised CPI data, prepared with CARTAC assistance. Coverage of other key macroeconomic variables needs improvement in terms of quality, periodicity, and timeliness of release.

Acknowledging recent improvements, staff urged the authorities to increase the frequency and timeliness of data provision. Staff welcomed the authorities' consent to subscribe to the IMF's General Data Dissemination System (GDDS), reinforcing Guyana's commitment to improved transparency and data dissemination.

\section{Staff Appraisal}

21. Guyana's future looks brighter, despite the many challenges. With a fifth consecutive year of economic growth, Guyana is beginning to lock in gains from recent years of fiscal consolidation. Prudent and sustained macroeconomic policies have developed resilience in the face of external and domestic shocks. There are growing indications that the private sector is building up major plans for the exploitation of Guyana's sizeable natural resources, while the public sector is proceeding with large investments in infrastructure, including in the electrical sector. Over the medium term, the LCDS should help Guyana compete better on the global stage and unleash opportunities for lowering poverty.

22. The authorities' commitment to fiscal consolidation and debt sustainability is welcome, given the risks to the outlook. Staff is encouraged by the authorities' determination in maintaining a prudent fiscal stance to protect debt sustainability over the 
medium term. Given the uncertainties associated with grants, the authorities would be well advised to consider building flexible budget plans including contingency measures to respond to any shortfall in disbursements. Staff reaffirmed the need for Guyana to keep seeking access to high concessional terms to protect debt sustainability.

\section{Improved fiscal performance will require greater efficiency in the public} enterprise sector. The public company GUYSUCO continues to underperform on output targets and its financial position remains weak. So far, the expected returns from major capital injections in this company and efforts to revamp the sugar industry have not materialized. Given the significantly improved world market conditions for sugar, there is a need to promptly resolve outstanding technical issues at the production site and to improve labor relations in a sustainable manner.

24. With the development of the large Amaila Falls project, fiscal risks associated with the public-private-partnership need to be monitored carefully. Construction of the new hydropower plant is due to begin next year, with the financial arrangements close to final stage of preparation. Given the importance and size of this project, staff urged the authorities to monitor carefully the associated fiscal risks. Staff welcomed the level of transparency and public disclosure of the project to date, including reflecting any firm or contingent liabilities from PPPs in debt statistics, and encouraged the authorities to continue in this vein. Guyana's PPPs will require close attention to international best practices. Moreover, should the projected surge in solvent demand fail to materialize, there is a risk that GPL's finances could be adversely affected.

25. Monetary policy should remain supportive of macroeconomic stability, especially in light of higher commodity prices expected in the near term. Staff commends the authorities' ability to keep inflation relatively low, and welcome their readiness to address any inflationary pressures. Guyana's exchange rate arrangement has served the country well, though staff noted that moving toward more flexibility would provide a buffer against shocks.

26. Vigilance remains important for effective supervision of the financial system. Staff also welcomes improvement in financial sector indicators, including the decline in NPL ratios, higher provisioning, and lower ratios of borrower concentration and related-party credit operations. The forthcoming law establishing a credit bureau, along with revised legislation bringing the mortgage bank under the supervision of the central bank should also help enhance efficiency in the financial sector. At the same time, the program that extends tax exemptions and reserve requirements on mortgage loans at participating banks should be monitored closely, to avoid developing excessive exposures in households' balance sheets. Staff welcomes the authorities' efforts at implementing planned financial sector reforms.

27. The authorities' intention to finalize the PRSP is welcome. Staff encouraged a continued dialogue with all stakeholders to ensure broad participation and engagement at a 
national level to achieve consensus on Guyana's economic agenda. Staff welcomes ongoing work with donor support to cost the achievement of the MDGs, acknowledging the complexity of this exercise.

28. Improvements in data quality achieved in 2010 should be accompanied by a further strengthening in data availability. Staff commends the authorities for the very significant progress entailed in the finalization of the rebased GDP and CPI series. Staff also welcomes the authorities' decision to subscribe to the General Data Dissemination System (GDDS) which extends Guyana's commitment to transparency and data dissemination.

29. Staff recommends that the next Article IV consultation with Guyana be held on the standard 12-month cycle. 
Figure 1. Guyana: Comparative Regional Developments 1/

Guyana's growth performance is being susta ined...

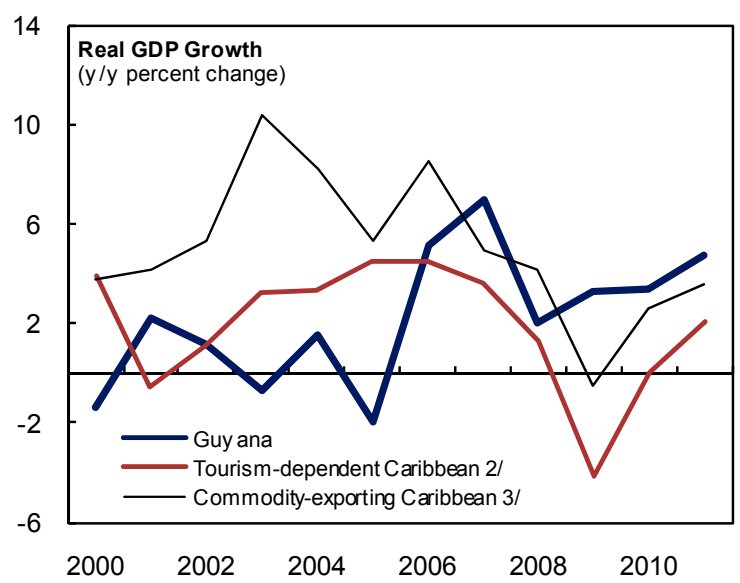

Fiscal consolidation has continued its course since the mid-decade.

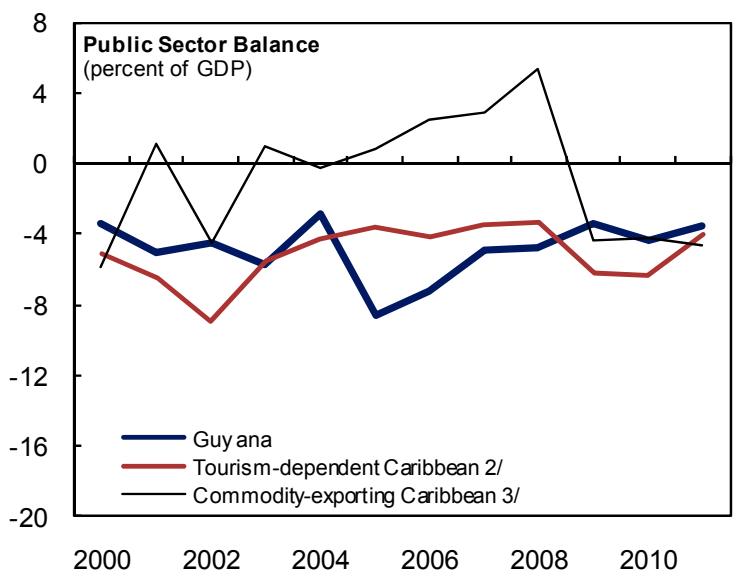

... while domestic debt is low for regional standards...

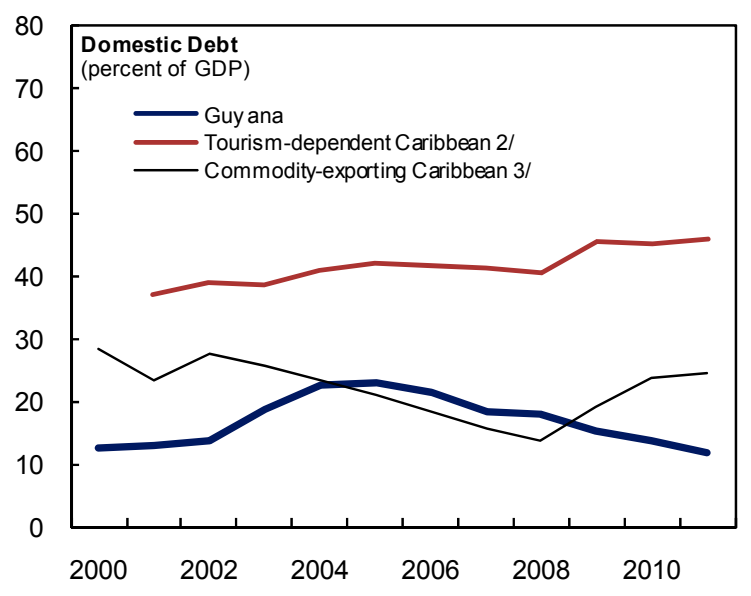

... while inflation rose, somewhat.

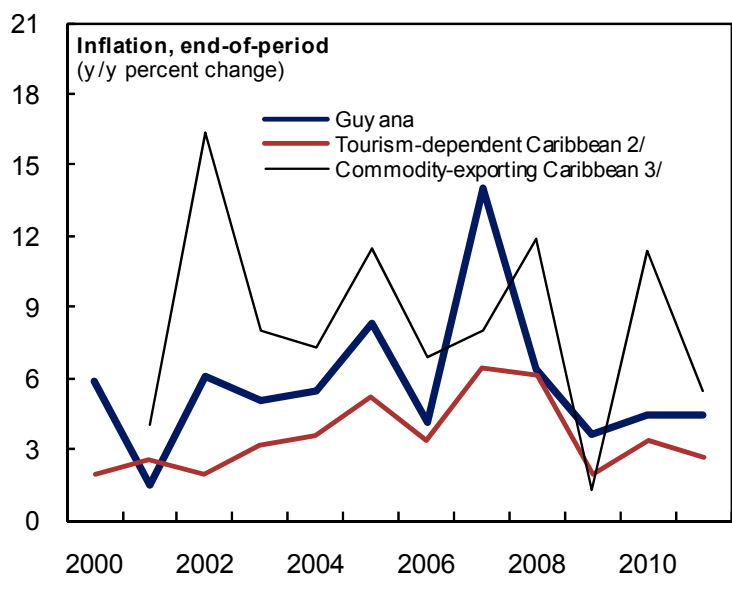

External debt has been brought to regional levels, supported by debt reduction operations...

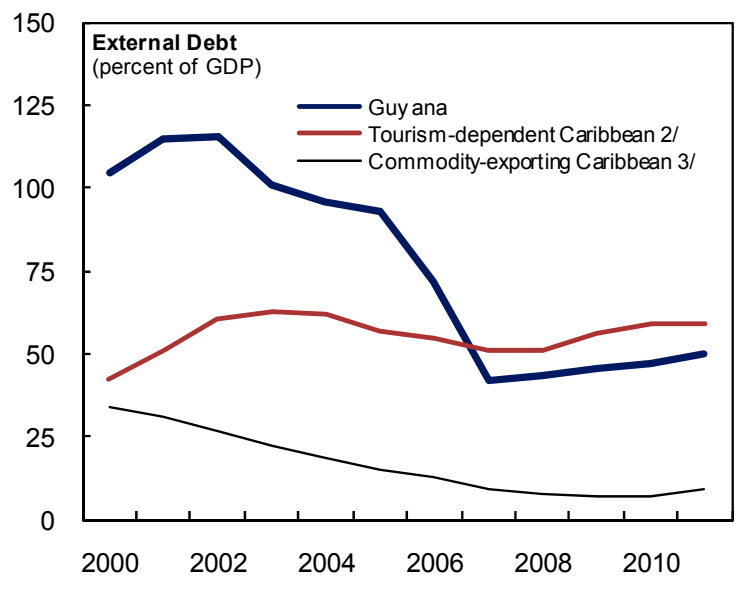

... but the current account deficit haswidened.

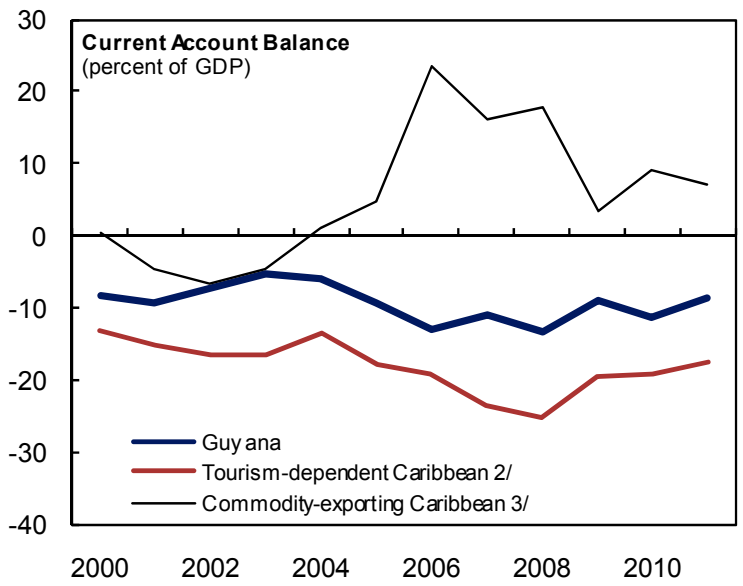

Sources: Countryauthorities; and Fund staff calculations.

$1 /$ Caribbean region measured as simple averages of corresponding variables.

2/Tourism-dependent Caribbean includes Antigua and Barbuda, Bahamas, Barbados, Belize, Dominica, Grenada, Jamaica, St. Kitts and Nevis, St. Lucia, and St. Vincent and the Grenadines.

3/Commodity-exporting Caribbean includes Suriname and Trinidad and Tobago. 
Figure 2. Guyana: Real Sector Indicators
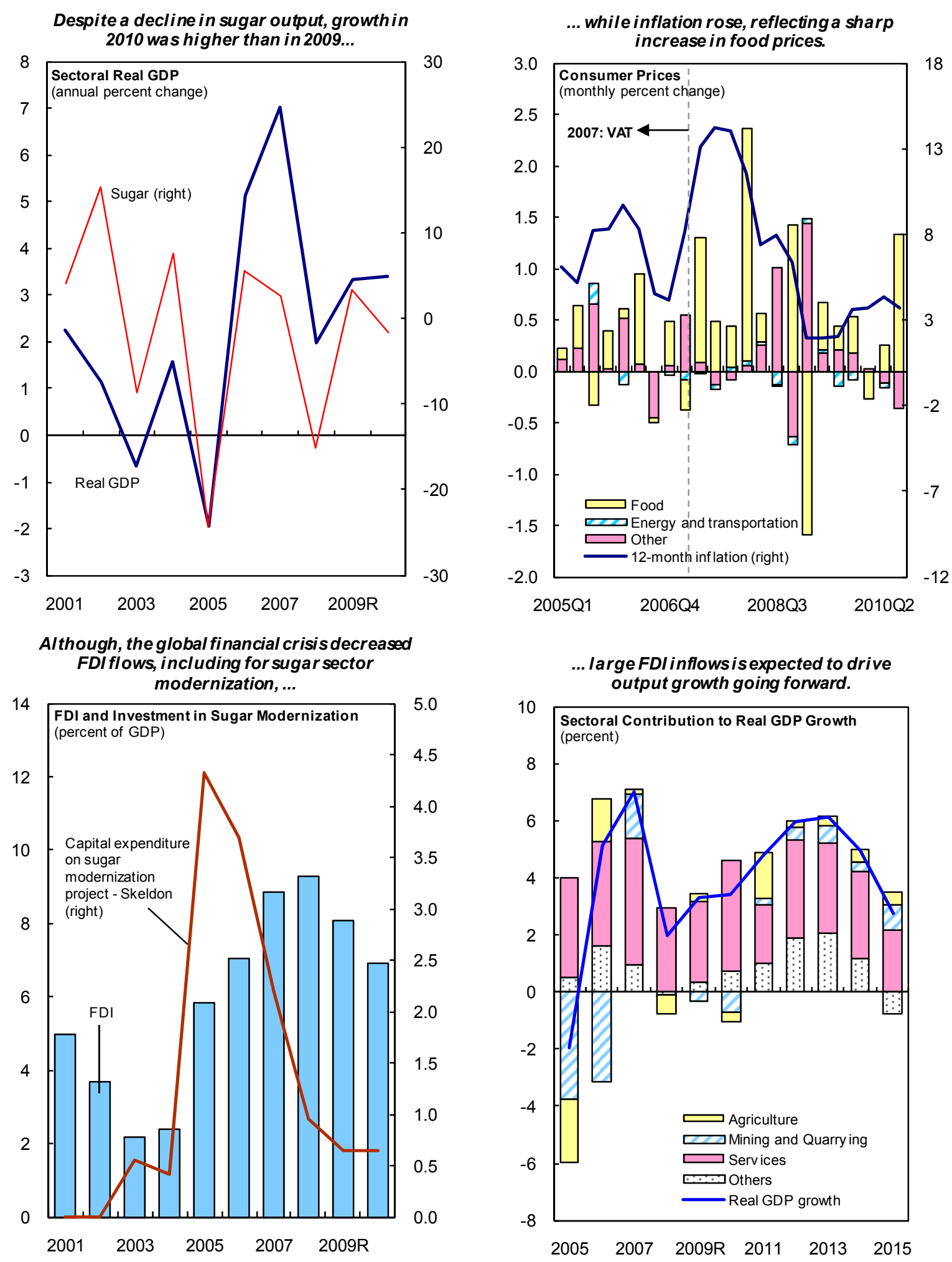

d

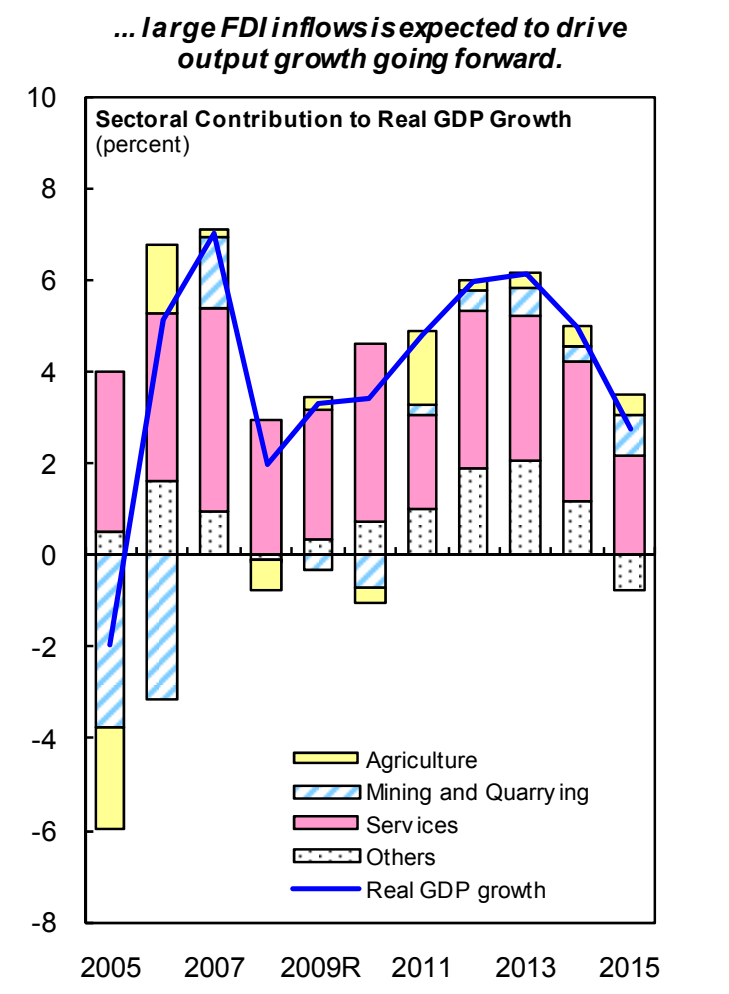

Sources: Bank of Guyana; Ministry of Finance; and Fund staff estimates. 
Figure 3. Guyana: External Sector Developments

Due to higher oil prices the currentaccount deficit is projected to widen in 2010 and over the medium term..

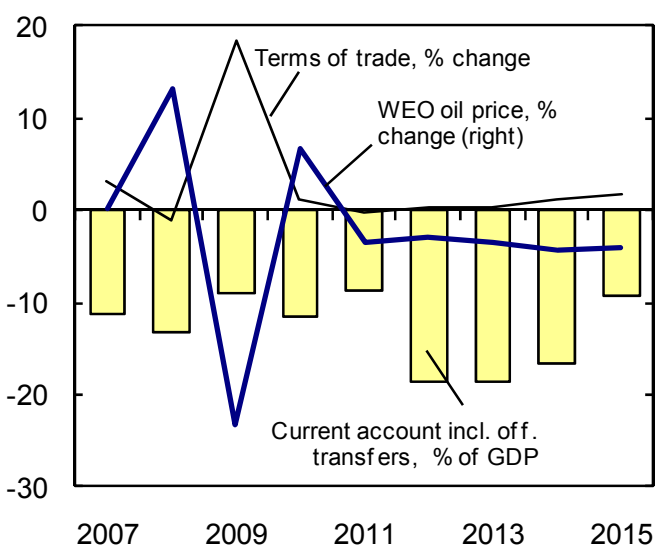

Exportsare projected to remain subduedas increased sugar production cannot compensa te the loss of EU preferences.

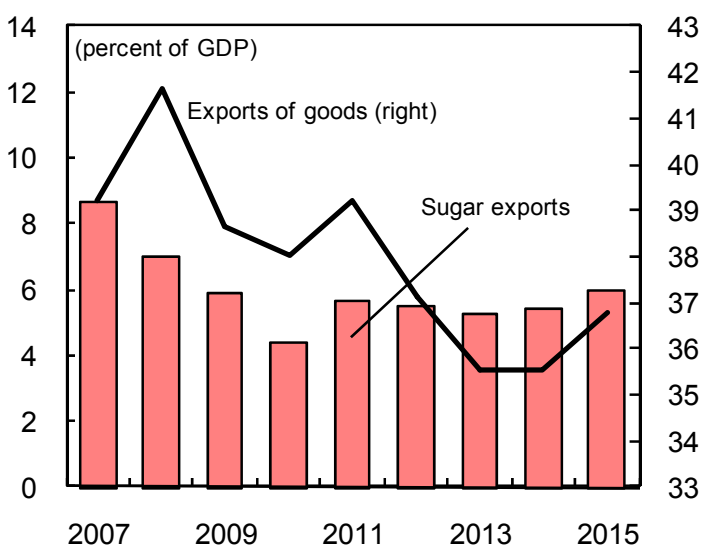

The current account deficit isfully financed by FDI, official ca pital transfers...

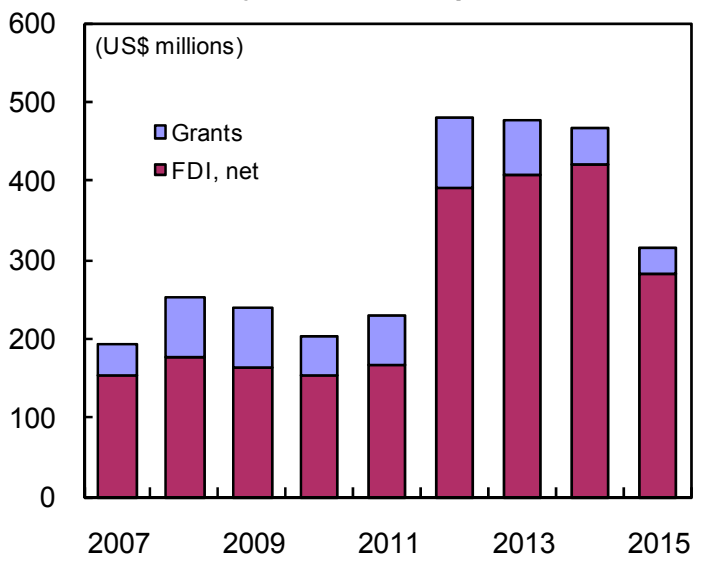

... a s imports of capital goods expand in line with the implementation of the AFHP project.

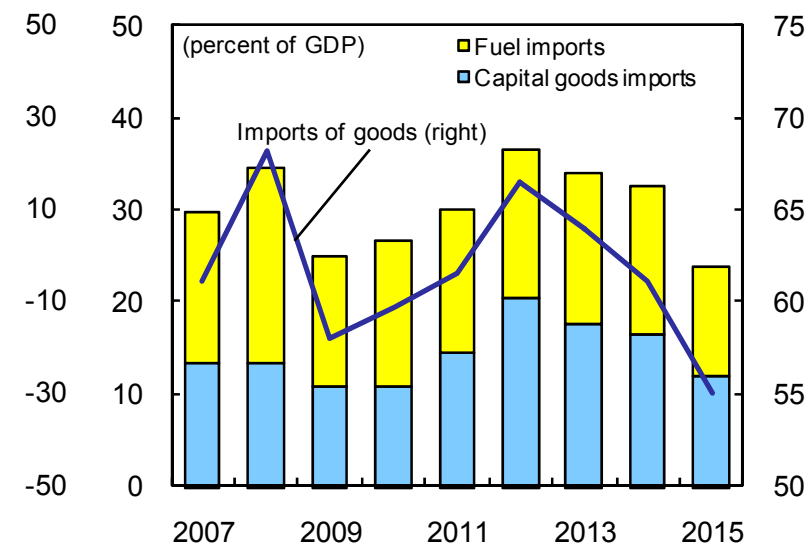

Remittances have remained stable despite the global crisis and a re projected to increase in line with the global recovery.

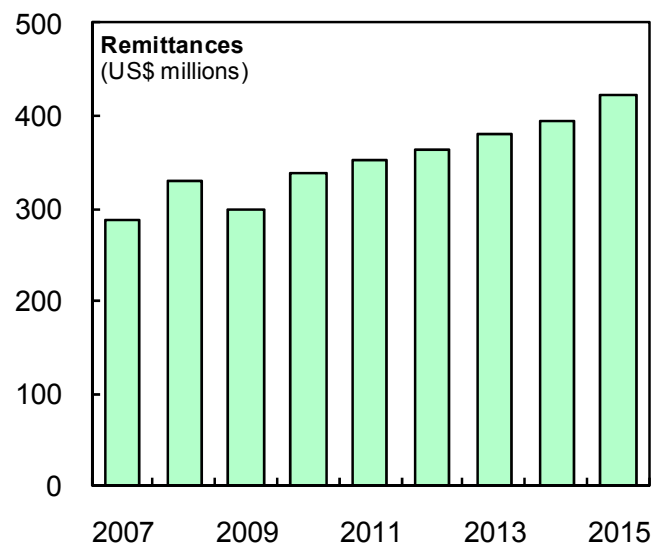

... and loans, with disbursements from Venezuela under the PetroCaribe agreement largely sa ved abroad.

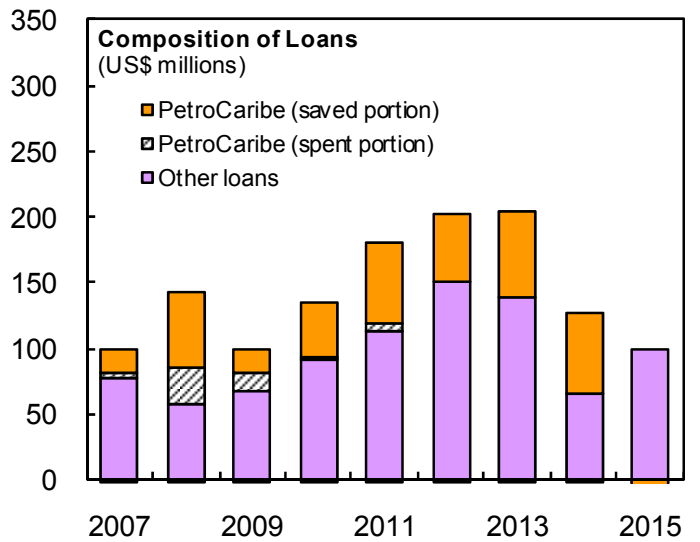

Sources: Bank of Guyana; and Fund staff estimates and projections. 
Figure 4. Guyana: Fiscal Sector Developments
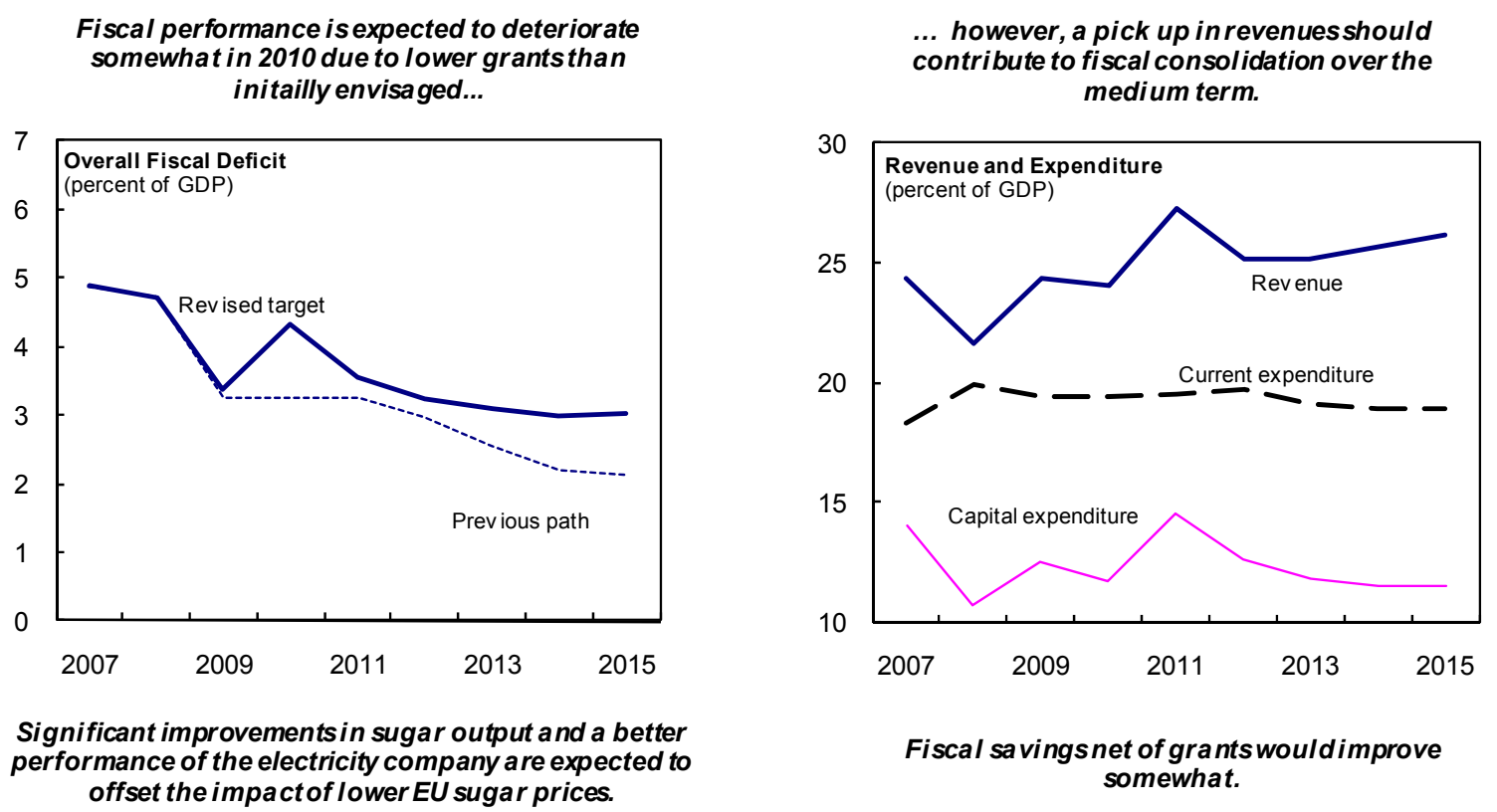

Fiscal sa vingsnet of grants wouldimprove somewhat.
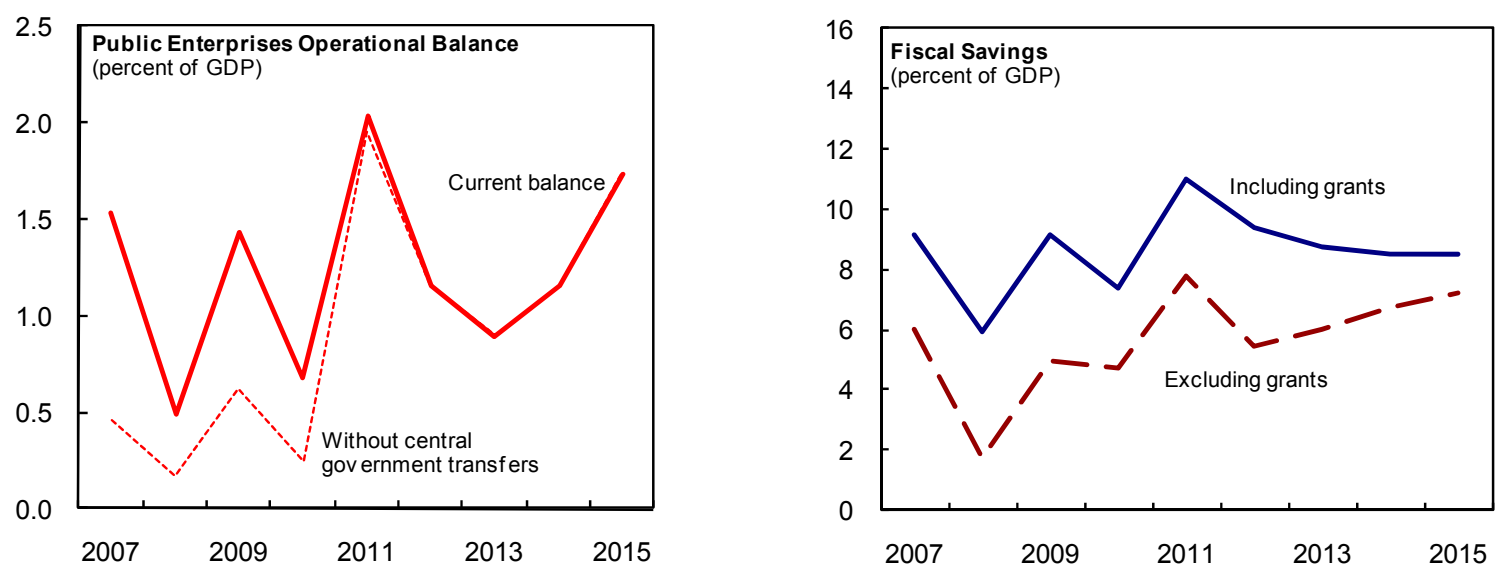

\section{Guyana, however, faces significant risksahead,} such as shortfalls in sugar production...

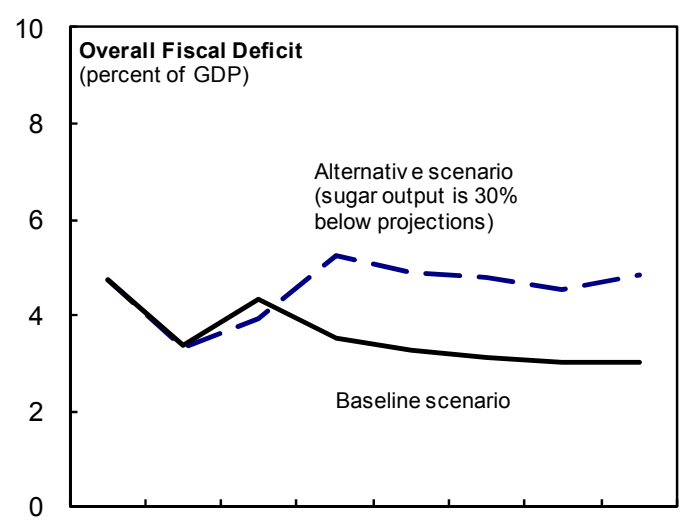

20082009201020112012201320142015

\section{... that would increase public sector debt.}

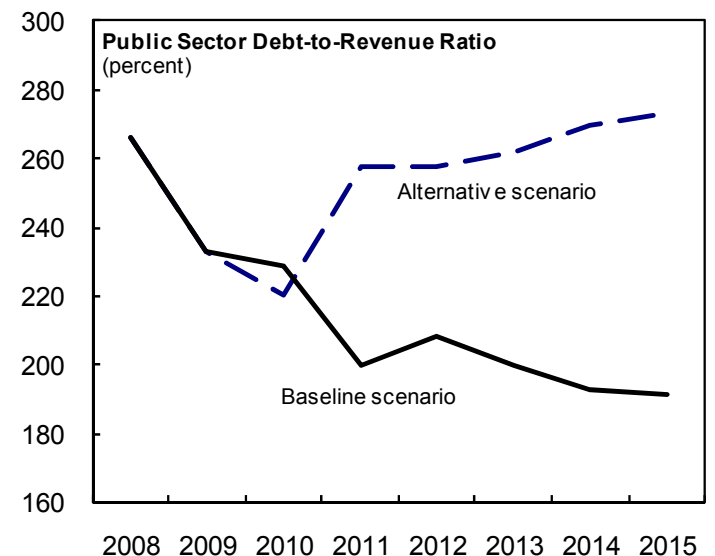

Sources: Ministry of Finance; and Fund staff estimates and projections. 
Figure 5. Guyana: Monetary Developments

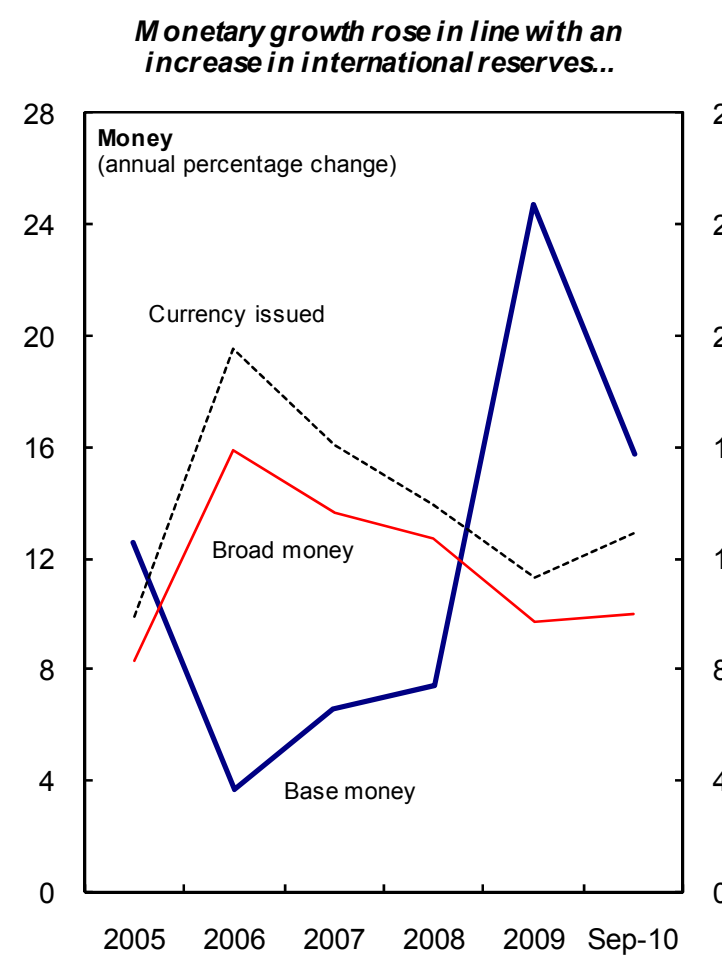

... interest rates remain steady.

M onetary growth rose in line with an

..interest ratesremain steady.

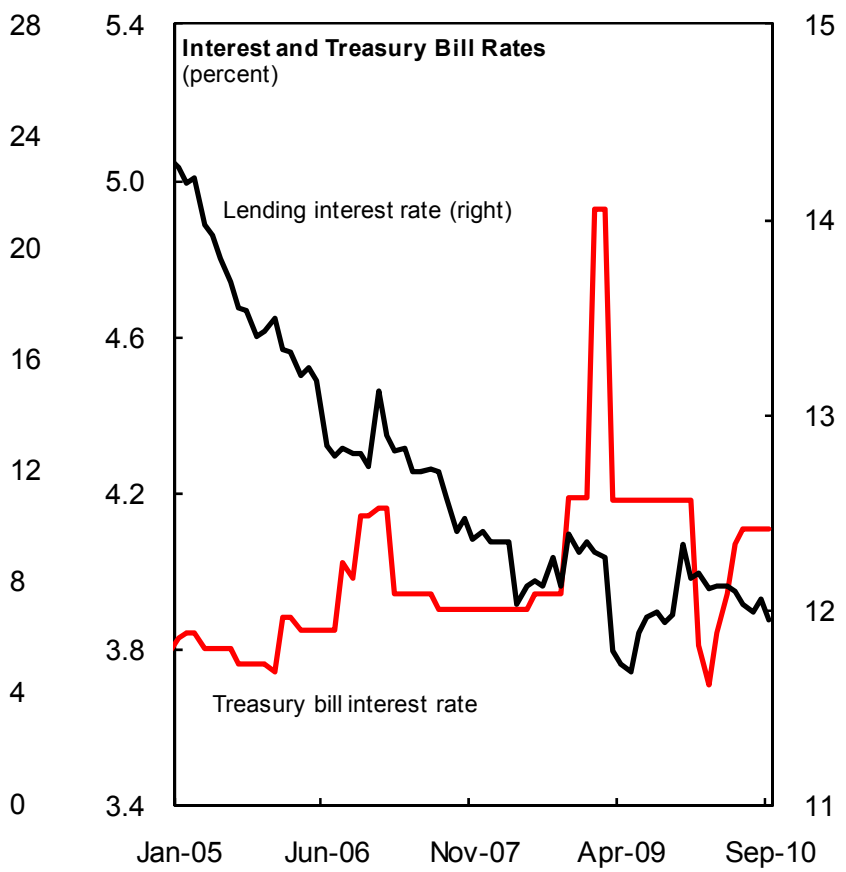

Nonetheless, creditgrowth has accelerated...

... across various sectors of the economy.

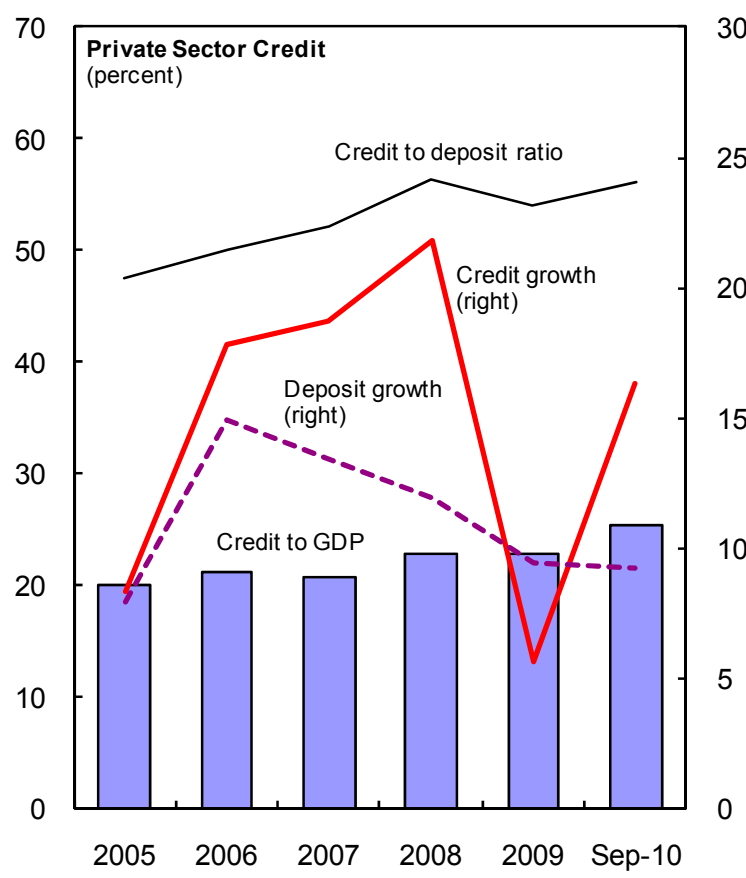

30

50

(annual percent change)

40

25

30

15

20

N

20

Households ${ }^{2} t^{2} i^{\prime \prime}$
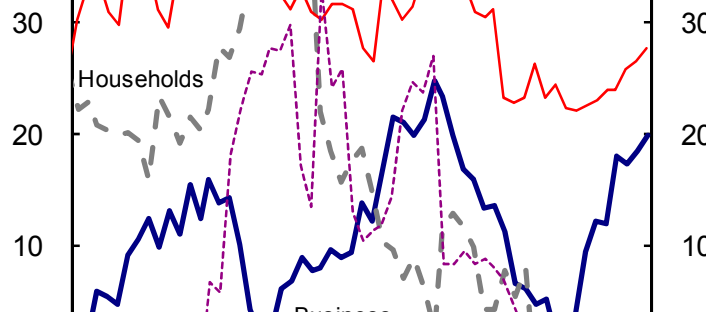

10

0
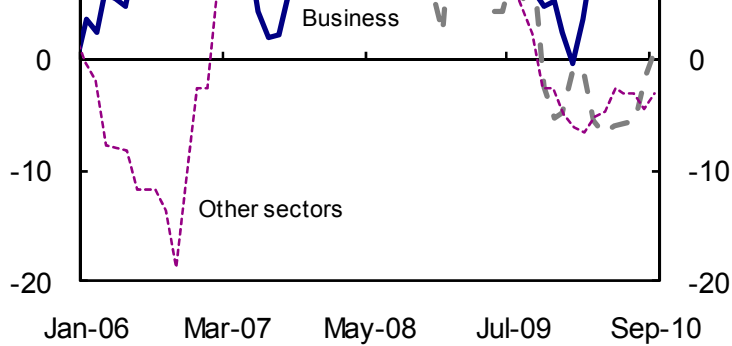

Source: Bank of Guyana Financial Statistics. 
Table 1. Guyana: Selected Social and Economic Indicators

I. Social Indicators

Population, 2009 (thousands)

769.8

66.5

Life expectancy at birth (years), 2007

55

Healthy life expectancy at birth (years), 2007

Population living below the poverty line (\%), 2000-06 35
II. Economic Indicators

Population not using an improved water source (\%), $2006 \quad 7.0$

Gini index, 1992-2007 44.6

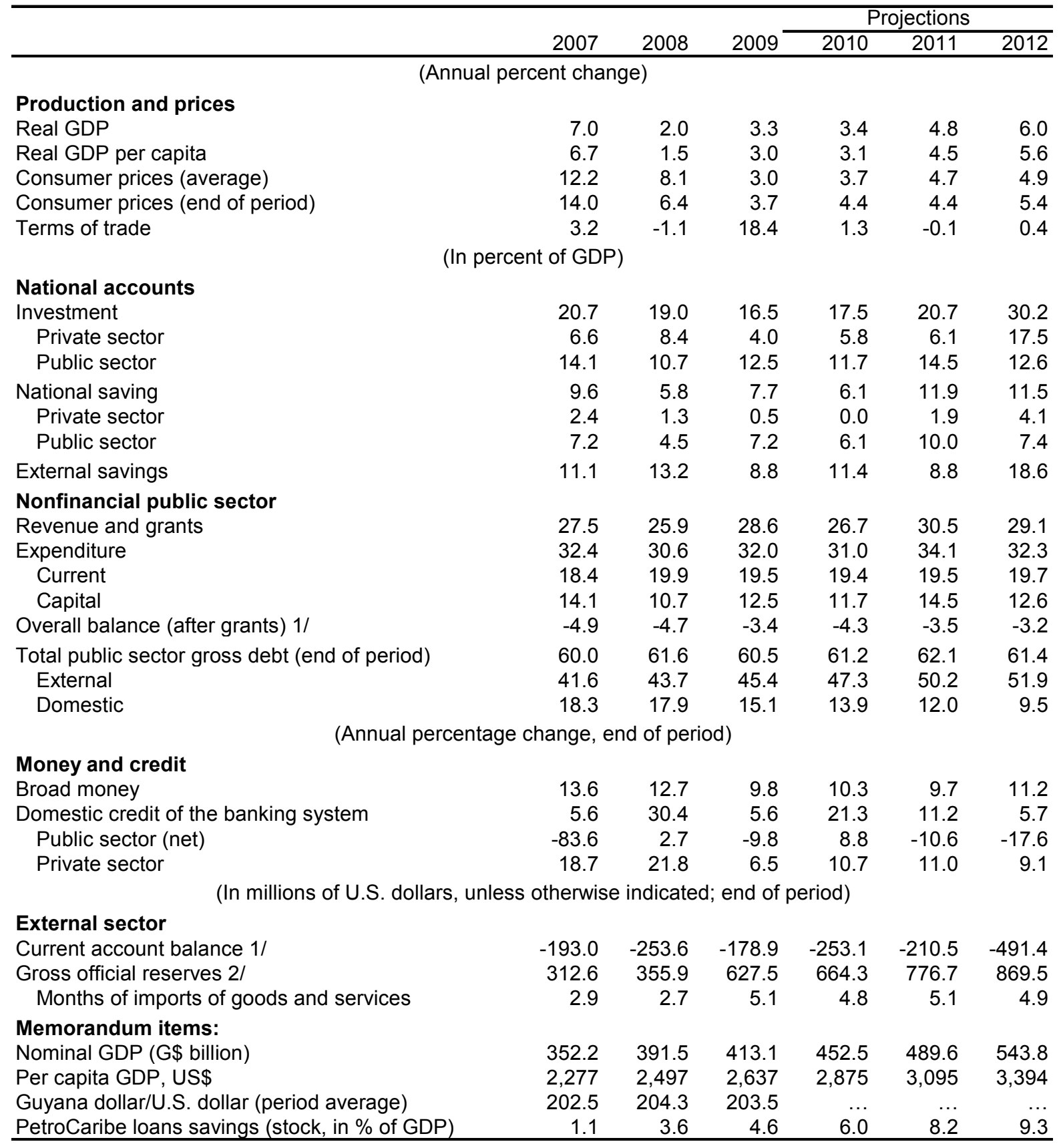

Sources: Guyanese authorities; UNDP Human Development Report; and Fund staff estimates and projections.

$1 /$ Including official transfers.

2/ Includes SDR allocation. 
Table 2. Guyana: Balance of Payments

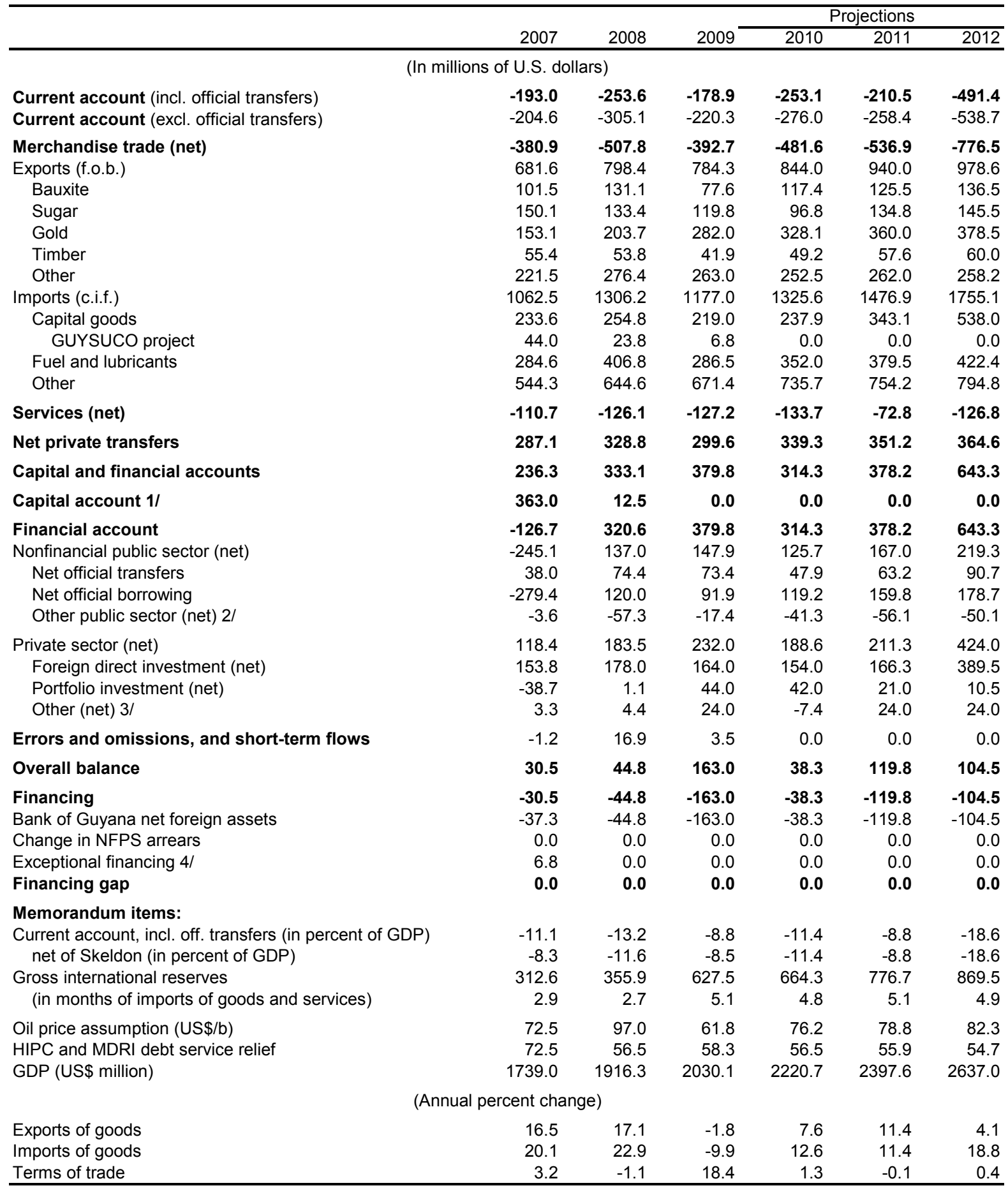

Sources: Bank of Guyana; Statistical Bureau of Guyana; Ministry of Finance; and Fund staff estimates and projections.

$1 /$ Includes the IDB's stock of debt operation in 2007

2/ Includes capital flows of PetroCaribe financing.

$3 /$ Includes capital flows to finance the Berbice bridge and short-term capital flows

4/ Includes the debt forgiveness on IDB loans in 2007 as the result of the MDRI. 
Table 3. Guyana: Nonfinancial Public Sector Operations

\begin{tabular}{|c|c|c|c|c|c|c|}
\hline & \multirow[b]{2}{*}{2007} & \multirow[b]{2}{*}{2008} & \multirow[b]{2}{*}{2009} & \multicolumn{3}{|c|}{ Projections } \\
\hline & & & & 2010 & 2011 & 2012 \\
\hline \multicolumn{7}{|c|}{ (In percent of GDP) } \\
\hline Revenue & 24.4 & 21.7 & 24.4 & 24.1 & 27.3 & 25.2 \\
\hline Central government & 22.8 & 21.2 & 23.0 & 23.4 & 25.4 & 24.0 \\
\hline Tax revenue & 22.0 & 20.2 & 21.6 & 22.4 & 21.3 & 21.4 \\
\hline Non-tax revenue & 0.9 & 0.9 & 1.4 & 1.0 & 1.0 & 1.1 \\
\hline GRIF & 0.0 & 0.0 & 0.0 & 0.0 & 2.9 & 1.5 \\
\hline Capital revenue & 0.0 & 0.1 & 0.0 & 0.0 & 0.0 & 0.0 \\
\hline Public enterprises & 1.5 & 0.5 & 1.4 & 0.6 & 1.9 & 1.2 \\
\hline Expenditure (excluding Skeldon) & 30.2 & 29.7 & 31.3 & 30.4 & 33.9 & 32.3 \\
\hline Current expenditure & 18.4 & 19.9 & 19.5 & 19.4 & 19.5 & 19.7 \\
\hline Wages and salaries & 6.2 & 6.1 & 6.3 & 6.3 & 6.4 & 6.3 \\
\hline Other goods and services $1 /$ & 5.8 & 6.2 & 6.3 & 6.2 & 6.4 & 6.4 \\
\hline Transfers & 4.6 & 6.0 & 5.3 & 5.1 & 5.1 & 5.5 \\
\hline Interest 2/ & 1.8 & 1.7 & 1.6 & 1.7 & 1.6 & 1.6 \\
\hline Domestic & 0.9 & 0.8 & 0.8 & 0.9 & 0.8 & 0.7 \\
\hline External & 0.9 & 0.9 & 0.8 & 0.9 & 0.8 & 0.9 \\
\hline Capital expenditure (excluding Skeldon) & 11.8 & 9.7 & 11.9 & 11.0 & 14.4 & 12.6 \\
\hline External PSIP & 6.8 & 5.4 & 4.1 & 3.9 & 4.5 & 7.2 \\
\hline GRIF Projects & $\ldots$ & $\ldots$ & $\ldots$ & $\ldots$ & 2.9 & 1.5 \\
\hline Local PSIP & 5.4 & 3.9 & 6.3 & 5.3 & 4.2 & 2.7 \\
\hline Public enterprises & -0.3 & 0.4 & 0.7 & 1.5 & 2.2 & 1.3 \\
\hline PetroCaribe projects & $\cdots$ & $\cdots$ & 0.8 & 0.4 & 0.6 & 0.0 \\
\hline Overall balance before grants (excluding Skeldon) & -5.8 & -8.0 & -6.9 & -6.3 & -6.6 & -7.2 \\
\hline Grants 3/ & 3.2 & 4.2 & 4.2 & 2.6 & 3.2 & 3.9 \\
\hline Overall balance after grants (excluding Skeldon) & -2.7 & -3.8 & -2.7 & -3.7 & -3.4 & -3.2 \\
\hline Capital expenditure on Skeldon & 2.2 & 1.0 & 0.6 & 0.6 & 0.2 & 0.0 \\
\hline Overall balance after grants & -4.9 & -4.7 & -3.4 & -4.3 & -3.5 & -3.2 \\
\hline Financing & 4.9 & 4.7 & 3.4 & 4.3 & 3.5 & 3.2 \\
\hline Net foreign financing $2 /$ & 5.5 & 6.8 & 4.9 & 5.9 & 7.0 & 6.4 \\
\hline Net domestic financing 4/ & 0.5 & 0.5 & -0.7 & 0.3 & -0.9 & -1.3 \\
\hline PetroCaribe savings & -1.1 & -2.6 & -0.9 & -1.9 & -2.6 & -1.9 \\
\hline \multicolumn{7}{|l|}{ Memorandum items: } \\
\hline NPFS wage bill & 12.2 & 11.5 & 11.1 & 10.9 & 11.0 & 10.5 \\
\hline Total capital expenditure & 14.1 & 10.7 & 12.5 & 11.7 & 14.5 & 12.6 \\
\hline Current balance before grants & 6.0 & 1.7 & 4.9 & 4.7 & 7.8 & 5.4 \\
\hline Primary balance (excluding Skeldon) & -0.9 & -2.1 & -1.2 & -1.9 & -1.8 & -1.7 \\
\hline Nominal GDP at market prices (G\$ billion) & 352.2 & 391.5 & 413.1 & 452.5 & 489.6 & 543.8 \\
\hline
\end{tabular}

Sources: Ministry of Finance; and Fund staff estimates and projections.

$1 /$ Includes fiscal consolidation measures.

2/ Reflects interest and amortization after debt stock operations.

3/ Includes debt service savings under the MDRI.

4/ Includes statistical discrepancies. 
Table 4. Guyana: Summary Account of the Bank of Guyana and Monetary Survey

\begin{tabular}{|c|c|c|c|c|c|c|}
\hline & \multirow[b]{2}{*}{2007} & \multirow[b]{2}{*}{2008} & \multirow[b]{2}{*}{2009} & \multicolumn{3}{|c|}{ Projections } \\
\hline & & & & 2010 & 2011 & 2012 \\
\hline \multicolumn{7}{|c|}{ (In billions of Guyanese dollars, end of period) } \\
\hline \multicolumn{7}{|c|}{ I. Bank of Guyana } \\
\hline Net foreign assets & 44.7 & 54.2 & 86.8 & 94.9 & 119.5 & 142.2 \\
\hline Foreign assets & 63.6 & 73.0 & 127.7 & 135.4 & 158.6 & 178.9 \\
\hline Foreign liabilities $1 /$ & -19.0 & -18.8 & -40.9 & -40.6 & -39.1 & -36.6 \\
\hline Net domestic assets & -14.9 & -19.7 & -48.4 & -52.7 & -73.9 & -91.6 \\
\hline \multicolumn{7}{|l|}{ Of which: } \\
\hline Credit to public sector (net) $1 /$ & -38.6 & -18.5 & -36.4 & -65.8 & -65.8 & -65.8 \\
\hline Liabilities to commercial banks & -24.7 & -23.6 & -34.7 & -37.3 & -40.7 & -45.7 \\
\hline Other items (net) & 51.9 & 39.5 & 41.3 & 79.4 & 61.7 & 48.9 \\
\hline Currency in circulation & 29.8 & 34.6 & 38.4 & 42.1 & 45.6 & 50.6 \\
\hline Base money & 51.1 & 54.9 & 68.4 & 78.8 & 86.9 & 97.0 \\
\hline Of which: Excess reserves & 1.3 & 1.1 & 1.6 & 4.9 & 4.3 & 3.6 \\
\hline \multicolumn{7}{|c|}{ II. Monetary Survey } \\
\hline Net foreign assets & 83.1 & 94.1 & 116.1 & 129.3 & 149.6 & 167.7 \\
\hline Bank of Guyana 1/ & 44.7 & 54.2 & 86.8 & 94.9 & 119.5 & 142.2 \\
\hline Commercial banks & 38.5 & 39.9 & 29.2 & 34.4 & 30.1 & 25.4 \\
\hline Net domestic assets & 80.3 & 90.0 & 86.1 & 93.6 & 94.9 & 104.2 \\
\hline Credit to public sector (net) $1 / 2 /$ & -19.1 & -18.5 & -20.4 & -30.3 & -33.6 & -39.5 \\
\hline Private sector credit & 73.3 & 89.3 & 95.1 & 104.4 & 116.0 & 126.5 \\
\hline Other items (net) & 26.0 & 19.2 & 11.3 & 19.5 & 12.5 & 17.1 \\
\hline Broad money & 163.4 & 184.2 & 202.2 & 222.9 & 244.5 & 271.9 \\
\hline \multicolumn{7}{|c|}{ (Percentage change, 12-month basis) } \\
\hline Net foreign assets & 49.9 & 13.3 & 23.3 & -9.0 & 15.7 & 12.1 \\
\hline Net domestic assets & -9.1 & 12.1 & -4.4 & 55.8 & 1.4 & 9.8 \\
\hline $\begin{array}{l}\text { Domestic credit } \\
\text { Of which: }\end{array}$ & 5.6 & 30.4 & 5.6 & 21.3 & 11.2 & 5.7 \\
\hline Private sector credit & 18.7 & 21.8 & 6.5 & 10.7 & 11.0 & 9.1 \\
\hline Business sector & 7.7 & 24.9 & 2.3 & $\ldots$ & $\ldots$ & $\ldots$ \\
\hline Household sector & 35.9 & 2.4 & -4.7 & $\ldots$ & $\ldots$ & $\ldots$ \\
\hline Mortgage sector & 31.0 & 33.6 & 24.4 & $\ldots$ & $\ldots$ & $\ldots$ \\
\hline Other sectors & 13.4 & 27.0 & -5.0 & $\ldots$ & $\ldots$ & $\ldots$ \\
\hline Public sector net & -83.6 & 2.7 & -9.8 & 8.8 & -10.6 & -17.6 \\
\hline Broad money & 13.6 & 12.7 & 9.8 & 10.3 & 9.7 & 11.2 \\
\hline \multicolumn{7}{|c|}{ (Contribution to changes in base money, 12-month basis) } \\
\hline Base money & 6.6 & 7.5 & 24.7 & 15.1 & 10.3 & 11.6 \\
\hline Net foreign assets & 16.8 & 18.7 & 59.4 & 11.7 & 31.3 & 26.2 \\
\hline Other including net credit to public sector & -10.2 & -11.3 & -34.7 & 3.4 & -21.0 & -14.6 \\
\hline \multicolumn{7}{|c|}{ (In million of U.S. dollars, unless otherwise indicated) } \\
\hline \multicolumn{7}{|l|}{ Memorandum items: } \\
\hline Bank of Guyana's net foreign assets 1/ & 219.5 & 264.2 & 427.3 & 465.5 & 585.3 & 689.9 \\
\hline Commercial banks' net foreign assets & 188.9 & 194.5 & 143.9 & 171.3 & 147.3 & 123.3 \\
\hline Money multiplier & 3.2 & 3.4 & 3.0 & 2.8 & 2.8 & 2.8 \\
\hline Income velocity of broad money & 2.2 & 2.1 & 2.0 & 2.0 & 2.0 & 2.0 \\
\hline Excess reserves (ratio to required reserves) & 0.1 & 0.0 & 0.1 & 0.2 & 0.1 & 0.1 \\
\hline Average lending rates, in percent & 12.4 & 12.3 & 12.2 & $\ldots$ & $\ldots$ & $\ldots$ \\
\hline
\end{tabular}

Sources: Bank of Guyana, and Fund staff estimates and projections.

$1 /$ Includes Fund debt relief.

2/ Includes G\$1.8 billion, a share of GUYMINE debt transferred from foreign assets to government credit in March 2006. 
Table 5. Guyana: External Financing Requirements and Sources

(In millions of U.S. dollars)

\begin{tabular}{|c|c|c|c|c|c|c|c|c|c|}
\hline & \multirow[b]{2}{*}{2007} & \multirow[b]{2}{*}{2008} & \multirow[b]{2}{*}{2009} & \multicolumn{6}{|c|}{ Projections } \\
\hline & & & & 2010 & 2011 & 2012 & 2013 & 2014 & 2015 \\
\hline Financing requirement & 620 & 372 & 391 & 330 & 398 & 666 & 637 & 556 & 428 \\
\hline External current account deficit & & & & & & & & & \\
\hline (excludes official transfers) & 205 & 305 & 220 & 276 & 258 & 539 & 578 & 546 & 334 \\
\hline Debt amortization & 379 & 24 & -101 & 17 & 28 & 35 & 39 & 44 & 48 \\
\hline NFPS amortization 1/ & 379 & 22 & 8 & 15 & 20 & 23 & 28 & 32 & 38 \\
\hline $\begin{array}{l}\text { Bank of Guyana amortization 2/ } \\
\text { Of which: }\end{array}$ & 0 & 2 & -109 & 1 & 7 & 12 & 12 & 12 & 10 \\
\hline IMF net credit & 0 & 0 & 0 & 1 & 7 & 12 & 12 & 12 & 10 \\
\hline Gross international reserves (increase $=+$ ) & 37 & 43 & 272 & 37 & 112 & 93 & 20 & -34 & 46 \\
\hline Available financing & 620 & 372 & 391 & 330 & 398 & 666 & 637 & 556 & 428 \\
\hline Capital transfers (MDRI) & 363 & 13 & 0 & 0 & 0 & 0 & 0 & 0 & 0 \\
\hline Official transfers & 38 & 74 & 73 & 48 & 63 & 91 & 69 & 46 & 35 \\
\hline NFPS loans & 99 & 142 & 100 & 135 & 180 & 202 & 205 & 127 & 74 \\
\hline Other public sector net 3 / & -4 & -57 & -17 & -41 & -56 & -50 & -65 & -60 & 24 \\
\hline Private sector (net) 4/ & 117 & 200 & 235 & 189 & 211 & 424 & 429 & 444 & 295 \\
\hline Exceptional financing & 7 & 0 & 0 & 0 & 0 & 0 & 0 & 0 & 0 \\
\hline Financing gap & $\mathbf{0}$ & 0 & 0 & 0 & 0 & 0 & 0 & 0 & 0 \\
\hline
\end{tabular}

Source: Fund staff estimates and projections.

1/ Scheduled amortization of NFPS before HIPC relief through 2003.

2/ Includes the SDR allocation of US\$108.6 million

$3 /$ Includes the unspent portion of PetroCaribe financing

4/ Including change of commercial banks NFA, short-term flows and trade credits, net foreign direct investment, and errors and omissions of balance of payments. 
Table 6. Guyana: Indicators of External and Financial Vulnerability (In percent, unless otherwise indicated)

\begin{tabular}{|c|c|c|c|c|c|c|c|c|c|}
\hline & \multirow[b]{2}{*}{2007} & \multirow[b]{2}{*}{2008} & \multirow[b]{2}{*}{2009} & \multicolumn{6}{|c|}{ Projections } \\
\hline & & & & 2010 & 2011 & 2012 & 2013 & 2014 & 2015 \\
\hline \multicolumn{10}{|l|}{ Financial indicators } \\
\hline Public sector debt-to-GDP 1/ & 60.0 & 61.6 & 60.5 & 61.2 & 62.1 & 61.4 & 61.4 & 61.6 & 60.8 \\
\hline NPV of public sector debt-to-GDP 1/ & 41.6 & 41.1 & 48.0 & 48.2 & 48.3 & 47.0 & 46.8 & 47.6 & 47.7 \\
\hline NPV of public sector debt-to revenue $1 /$ & 152.3 & 158.9 & 170.4 & 180.3 & 158.2 & 161.5 & 167.8 & 173.6 & 173.8 \\
\hline Share of nonperforming loans in total loans & 10.7 & 9.5 & 8.3 & $\ldots$ & $\ldots$ & $\ldots$ & $\ldots$ & $\ldots$ & ... \\
\hline Share of nonperforming loans to total assets & 3.7 & 3.6 & 3.0 & $\ldots$ & $\ldots$ & $\ldots$ & $\ldots$ & $\ldots$ & $\ldots$ \\
\hline Loan loss provisions to nonperforming loans & 54.2 & 49.3 & 53.8 & $\ldots$ & $\ldots$ & $\ldots$ & $\ldots$ & $\ldots$ & ... \\
\hline Risk-based capital-asset ratio (end of period) & 15.0 & 14.9 & 18.3 & $\ldots$ & $\ldots$ & $\ldots$ & $\ldots$ & $\ldots$ & $\ldots$ \\
\hline Return on assets & 2.4 & 2.3 & 2.7 & $\ldots$ & $\ldots$ & $\ldots$ & $\ldots$ & $\ldots$ & $\ldots$ \\
\hline Three-month T-bill rate (end of period) & 3.9 & 4.2 & 4.2 & $\ldots$ & $\ldots$ & $\ldots$ & $\ldots$ & $\ldots$ & $\ldots$ \\
\hline CPI-inflation (end of period) & 14.0 & 6.4 & 3.7 & 4.4 & 4.4 & 5.4 & 5.4 & 5.4 & 5.4 \\
\hline \multicolumn{10}{|l|}{ External indicators } \\
\hline Exchange rate (per US\$, end of period) & 204.0 & 205.0 & 203.3 & $\ldots$ & $\ldots$ & $\ldots$ & $\ldots$ & $\ldots$ & $\ldots$ \\
\hline REER appreciation (12-month basis, -=appreciation) & -2.9 & -0.3 & -6.5 & $\ldots$ & $\ldots$ & $\ldots$ & $\ldots$ & $\ldots$ & $\ldots$ \\
\hline Current account balance-to-GDP & -11.1 & -13.2 & -8.8 & -11.4 & -8.8 & -18.6 & -18.5 & -16.5 & -9.2 \\
\hline Gross official reserves (in millions of U.S. dollars) & 312.6 & 355.9 & 627.5 & 664.3 & 776.7 & 869.5 & 889.3 & 855.5 & 901.4 \\
\hline Gross official reserves in months of imports 2/ & 2.9 & 2.7 & 5.1 & 4.8 & 5.1 & 4.9 & 4.8 & 4.4 & 4.9 \\
\hline Gross official reserves to short-term external public sector debt & $2,228.0$ & $2,950.6$ & $5,021.5$ & $3,449.0$ & $2,513.3$ & $2,273.0$ & $2,072.0$ & $1,777.4$ & $1,739.0$ \\
\hline External public sector debt to GDP $1 /$ & 41.6 & 43.7 & 45.4 & 47.3 & 50.2 & 51.9 & 53.4 & 52.3 & 50.9 \\
\hline NPV of external public debt (in millions of U.S. dollars) $1 / 3 /$ & 422.8 & 556.1 & 667.1 & 761.9 & 870.9 & 989.1 & $1,116.1$ & $1,183.4$ & $1,224.9$ \\
\hline NPV of external public sector debt to exports $1 / 3$ / & 49.2 & 57.4 & 69.1 & 72.4 & 70.6 & 78.6 & 84.0 & 82.9 & 80.1 \\
\hline NPV of external public debt-to-central government revenue $1 / 3 /$ & 107.0 & 134.0 & 136.8 & 142.5 & 133.0 & 149.0 & 154.4 & 149.4 & 144.9 \\
\hline NPV of external public debt-to-GDP 1/ $3 /$ & 24.3 & 29.0 & 32.9 & 34.3 & 36.3 & 37.5 & 38.8 & 38.3 & 37.9 \\
\hline \multicolumn{10}{|l|}{ Memorandum item: } \\
\hline Public sector debt-to-GDP excluding unspent PetroCaribe 1/ 4/ & 58.9 & 57.7 & 56.0 & 55.1 & 54.6 & 52.4 & 50.3 & 49.5 & 50.1 \\
\hline
\end{tabular}

Sources: Bank of Guyana; and Fund staff estimates and projections.

1/ Reflects debt relief under O-HIPC, E-HIPC and MDRI as of 2007.

2/ Imports of the current year excluding those related to the GUYSUCO investment project.

3 / Excludes the letter of credit used for financing the sugar restructuring project for comparability with the debt definition for the NPV of external debt threshold.

4/ Excluding the unspent portion of PetroCaribe in 2007-15. 
Table 7. Guyana: Medium-Term Macroeconomic Framework

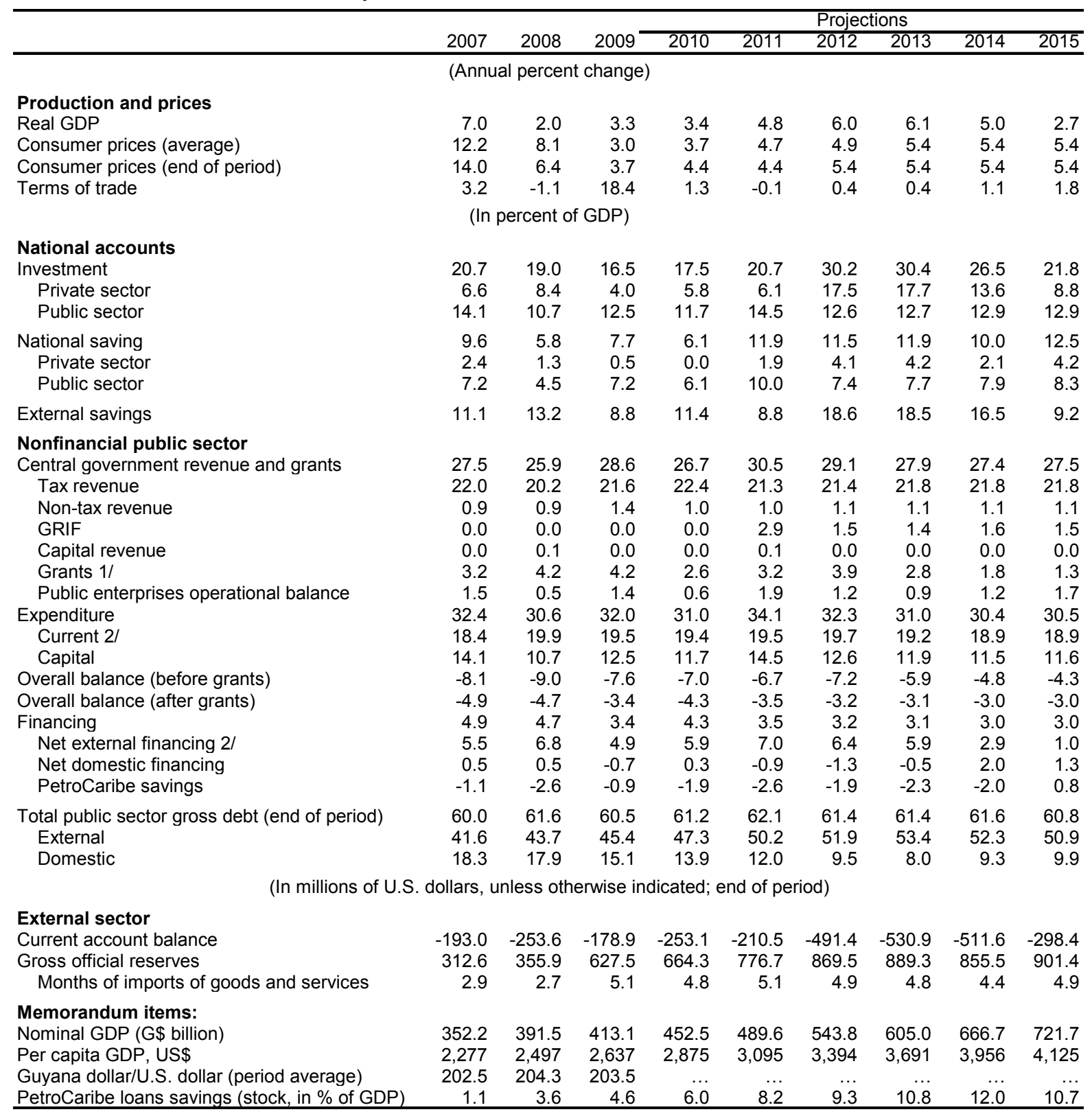

Sources: Guyanese authorities; and Fund staff estimates and projections.

$1 /$ Includes debt service savings under HIPC and MDRI.

2/ Reflects interest and amortizations after debt stock operations. 
Table 8. Guyana: Medium-Term Balance of Payments

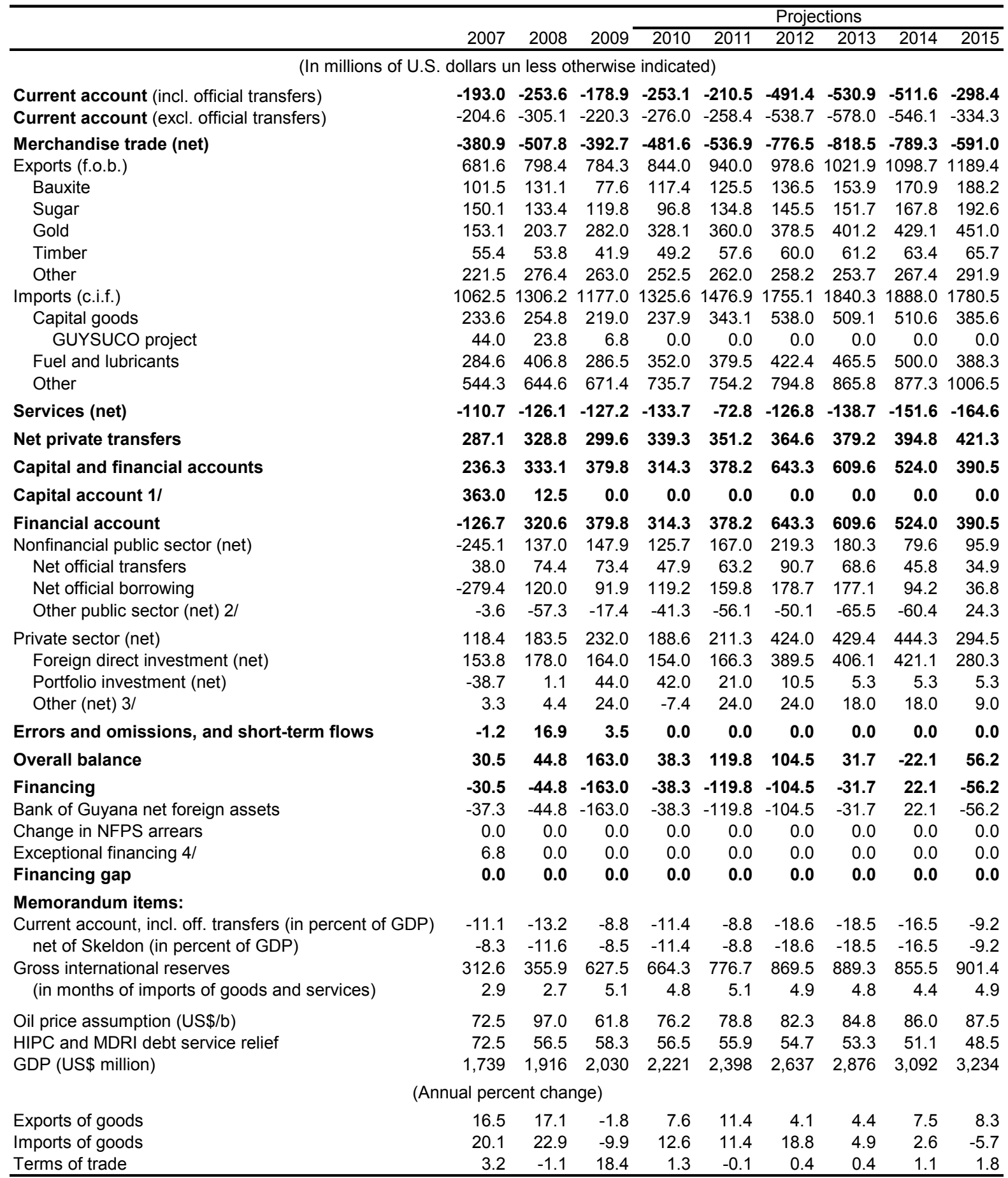

Sources: Bank of Guyana; Statistical Bureau of Guyana; Ministry of Finance; and Fund staff estimates and projections.

1/ Includes the IDB's stock of debt operation in 2007

2/ Includes capital flows of PetroCaribe financing.

$3 /$ Includes capital flows to finance the Berbice bridge and short-term capital flows

4/ Includes the debt forgiveness on IDB loans in 2007 as the result of the MDRI. 


\section{AtTaChMent I. GuYAna: The Low CARbon DeVElopment STRATEGy (LCDS)}

The Guyanese economy is on the cusp of major changes, led in part by the government's LCDS. In exchange for performance-based annual payments for forest services, Guyana will lower carbon emissions and enhance forest preservation in four phases between 2009 and 2020. The LCDS is projected to help raise the GDP growth, government revenue, employment, and foreign exchange earnings of Guyana.

1. After a period of successful stabilization, Guyana is now focused on achieving rapid economic transformation. Traditionally, economic activity has been driven by agriculture and mining, with a heavy dependence on imported fuels to generate energy, thereby exposing the economy to oil price volatility. Further sustained economic transformation is being constrained by insufficient investments in infrastructure, limited human capital and inadequate social services, which are barriers to private sector investment. Under the current development model, Guyana can secure the requisite development resources by fully exploiting its vast forest reserves and associated mineral deposits, but at a high environmental cost. ${ }^{1}$ This model is, however, no longer viewed as a sustainable or a preferred transformation option in the context of the global dialogue on climate change and Reduced Emissions from Deforestation and Degradation (REDD) mechanism.

\section{The LCDS provides a sustainable mechanism for Guyana to leverage its vast} forest reserves to fund economic transformation. Under the LCDS, Guyana will receive annual performance based payments for reducing carbon emissions by preserving its forest. The current proposal envisages implementing the LCDS over four phases from 2009 to 2020 (Table 1). Over that period of time, payments, mainly funded initially by the international public sector, would be made annually up to the phase when these payments would be market based and be matching or exceeding the Estimated Value to the Nation (EVN) (US\$580 million annually) of the forest reserve.

\section{Consistent with the LCDS, the Governments of Norway and Guyana have} pioneered a model of trading in environmental services at the global level. Under the terms of a memorandum of understanding (MOU between Guyana and Norway, 2009), Norway has pledged up to US\$250 million, over five years, as payments for forest services. To facilitate payments, a trust fund - Guyana REDD-Plus Investment Fund (GRIF) administered by the World Bank has been established and will receive and disburse these and other funds to projects identified under the LCDS through the IDB. The annual expected disbursement from the GRIF, starting in 2010, is US\$50 million. Annual payments will be made after Guyana's forest preservation performance is independently assessed and verified against agreed benchmarks.

\footnotetext{
${ }^{1}$ The Economic Value to the Nation (EVN) of the forest estate is estimated to be the equivalent of an annual annuity payment of US\$580 million, (LCDS).
} 
4. A verification mechanism has been agreed between Norway and Guyana for the use of funds. The mechanism has several aspects, but all guided by a Multi-Stake Holder Steering Committee (MSHSC) comprising representatives of Guyana and Norway, which will choose projects for funding and monitor disbursements. Under this mechanism the World Bank would act as trustee for the funds, and will disburse funds for approved projects once directed by the MSHSC. The disbursements and project implementation would be managed by the IDB and other identified partner entities. The approval and disbursement of funds would be in line with Guyana's national legal framework, and fiduciary and operational policies of the GRIF. The partner entities would also be responsible for ensuring certain safeguards - including fiduciary, social, economic and environment are in place, while the Ministry of Finance of Guyana will be responsible for the execution of the GRIF's operations. As such, these resources would be governed by the relatively strong PFM framework currently operational in Guyana. In addition to these, the Guyana/Norway agreement provides for the creation of a monitoring, reporting and evaluating system (MRVS), ${ }^{2}$ which will assess Guyana's performance relative to the environmental benchmarks. These arrangements are governed by the applicable domestic laws and procedures in Guyana.

5. The LCDS has five economic pillars: (i) low carbon economic infrastructurerenewable energy - hydro power, solar, biogas - access to non-forested land and underutilized land, improved bandwidth; (ii) developing high potential low-carbon sectorfruits and vegetables, aquaculture, and ecotourism; (iii) reforming the existing forest dependent sectors to ensure forest sustainability; (iv) enhancing human capital; and (v) improving the environment for doing business. Of these, the low carbon infrastructure projects - hydropower, fiber optic cable/technology park, drainage, irrigation, and road construction - are pivotal to the overall success of the LCDS. Low carbon infrastructure projects are estimated to cost approximately US\$1 billion.

6. In line with the pillars of the LCDS, the initial payments from Norway will be used to fund the following seven activities: (i) government equity in the Amaila Falls Hydro Electricity Company; (ii) Amerindian Development Fund; (iii) accelerating Amerindian land titling, demarcation and extension processes; (iv) expansion of fiber optic digital infrastructure; (v) micro-finance for small and medium enterprises and vulnerable groups' low carbon development; (vi) initial work to establish an international centre for biodiversity research and low carbon development; (vii) development of a monitoring, reporting and verification system for the LCDS.

\footnotetext{
${ }^{2}$ Apart from the MRVS and the GRIF, Guyana is developing three additional (new or enhanced) institutions to manage various aspects of the LCDS. First, an office of climate change, which will coordinate engagement with multilateral processes and negotiations, including the UNFCC. Second, a low carbon strategy project management office to steer key projects as part of the LCDS. And third, a strengthened environmental protection agency to ensure that local social and environmental safeguards meet international standards.
} 
7. The impact of the LCDS on growth and economic activity would be twofold. First the direct impact of the payments for forest services from Norway, if fully invested in transforming the economy, should add approximately 0.4 percent additional GDP growth a year. The more significant and long lasting impact would be the dynamic effects of these investments, aimed at transforming the economy.

The Direct Growth Impact of the Norway Payments under the LCDS

\begin{tabular}{lccccc}
\hline & 2011 & 2012 & 2013 & 2014 & 2015 \\
\hline Annual Payments from Norway (USDm) & 70.0 & 40.0 & 40.0 & 50.0 & 50.0 \\
Investment to GDP & 3.1 & 1.8 & 1.8 & 2.2 & 2.5 \\
ICOR & 5.4 & 5.4 & 5.4 & 5.4 & 5.4 \\
Growth Impact (in percent) & $\mathbf{0 . 6}$ & $\mathbf{0 . 3}$ & $\mathbf{0 . 3}$ & $\mathbf{0 . 4}$ & $\mathbf{0 . 5}$ \\
\hline
\end{tabular}

8. Guyana anticipates that higher employment, government revenues and foreign exchange earnings will result from the LCDS. Over a period of three years, the activities identified by the LCDS - tropical fruits and vegetables, aquaculture, lumber value chainwith a projected initial investment of US $\$ 215$ million, are expected to boost exports by approximately US $\$ 950$ million; increase government revenue by US\$190 million; create an additional 32,000 jobs and raise GDP by approximately US $\$ 40$ million. 
Table 1. Indicative Remuneration for LCDS

\begin{tabular}{|c|c|c|}
\hline Phase & $\begin{array}{l}\text { REDD+ Payments Available to } \\
\text { Guyana }\end{array}$ & Description \\
\hline $\begin{array}{l}\text { Phase } 1 \\
(2009)\end{array}$ & & $\begin{array}{l}\text { Interim payments to launch the LCDS } \\
\text { Includes funding for an MRV system in } \\
\text { Guyana }\end{array}$ \\
\hline $\begin{array}{l}\text { Phase } 2 \\
(2010-2015)\end{array}$ & $\begin{array}{l}\text { - Starts at: } \sim \$ 60 \text { million } \\
\text { - Ramps up to } \$ 230-\$ 350 \\
\text { million ( } 40 \%-60 \% \text { of EVN) }\end{array}$ & $\begin{array}{l}\text { - Transitional funding that will be used } \\
\text { for: } \\
\text { - Capacity building } \\
\text { - Investment required to build a low } \\
\text { carbon economy } \\
\text { - Human capital development }\end{array}$ \\
\hline $\begin{array}{l}\text { Phase } 3 \\
(2013-2020)\end{array}$ & $\begin{array}{l}\text { - Starts at: } \sim \$ 230-\$ 350 \\
\text { million }(40 \%-60 \% \text { of EVN) } \\
\text { - Ramps up to } \$ 580 \text { million } \\
(\mathrm{EVN})\end{array}$ & $\begin{array}{l}\text { - Continued payments to avoid } \\
\text { deforestation } \\
\text { - Payments will be used for further: } \\
\text { - Investments in low carbon economy } \\
\text { - Capacity building } \\
\text { - Climate change adaptation }\end{array}$ \\
\hline $\begin{array}{l}\text { Phase } 4 \\
\text { (2020 onwards) }\end{array}$ & $\begin{array}{l}\text { At or above EVN } \\
\text { ( }>\$ 580 \text { million) }\end{array}$ & $\begin{array}{l}\text { "At-scale" REDD mechanism should: } \\
\text { - Provide incentives at or above EVN } \\
\text { - Account for increasing value of the } \\
\text { forests }\end{array}$ \\
\hline
\end{tabular}

Source: LCDS, Exhibit 2. 


\section{Attachment II. Guyana: The Amaila Falls Hydro Power Plant (AFHP)}

The authorities are pressing ahead with the construction of the AFHP which would lower energy costs and improve energy reliability as it replaces outdated fuel-based technology with modern hydro-based technology as the main source of electricity generation.

1. Electricity generation in Guyana has been based on outdated technology, using imported high cost fuels. As a result, electricity supply has been unreliable and at a high cost (32 U.S. cents per Kilowatt hour), causing several private sector entities to install their own generation capacity. The dependence of electricity generation on imported fuels, of approximately US\$90 million a year, has also exposed the economy to the vagaries of international price movements. Guyana Power and Light (GPL) also suffers from an aging distribution network, and weak revenue administration.

\section{The AFHP is a key component of the government's Low Carbon Development} Strategy (LCDS). Energy generation would switch from being based on fossil-fuels to nearly 100 percent clean, renewable sources. Development gains would include eliminating a key barrier to FDI and lower electricity costs. A reduction of 20-40 percent per Kilowatt hour is expected for the tariffs of residential, commercial, and industrial consumers as GPL switches out of oil based to hydro-power based electricity generation. The Government of Guyana would earmark US\$40-60 million of the LCDS-related payments to increase its equity in the project. The AFHP is estimated to cost approximately US\$650 million, equivalent to 30 percent of GDP. Construction is scheduled to commence in the third quarter of 2011 and be completed in 40 months. Upon completion in 2014, the AFHP would cover all the electricity needs of Guyana - approximately 154 megawatts.

\section{The AFHP would be constructed as a Private Sector-Public Sector Partnership} (PPP). A local company - the Amaila Falls Hydro Inc. (AFHI) company-has been established, with shareholdings by Sithe Global (the Sponsor) and GPL. This company would build, and then operate the AFHP for 20 years, after which it would revert to the government. Based on information currently available (the financial arrangement is still under negotiation), the AFHI would contract debt of approximately US\$500 million (70 percent of total project cost). The remainder would come from equity injections by the sponsor and the government, who would contribute by way of the access road to the project site. The project sponsor has been guaranteed a 20 percent rate of return which, according to the IDB, is comparable to similar projects in other low income countries.

\section{The central component of the PPP is a Power Purchasing Agreement (PPA)} between GPL and the sponsor. The project is structured as a 20-year "take or pay" PPA through which GPL will purchase 100 percent of the generation capacity for an annual payment of approximately US\$100 million that will help achieve the guaranteed 20 percent return on the sponsor's equity. This arrangement will be collateralized by GPL's receivables. 
Further, the design of the PPP would allow the government to increase its equity share and, by extension, reduce its obligation to the sponsor.

\section{The AFHP is expected to have a transformational impact on the Guyanese} economy, but also poses large fiscal risks, should it fail to deliver the promised benefits. Among the likely benefits and potential costs would be the following:

- Growth: During construction (2012-14), the project is likely to add cumulatively 6 percentage points of real GDP growth. Further economic gains, once the project is completed, would depend on the adopted tariff structure, and the impact of this on total factor productivity and capital accumulation and its quality. Based on current information, it is expected that the AFHP would eventually result in a $20-40$ percent reduction in the cost of generation as the switch from oil to hydro takes hold; the

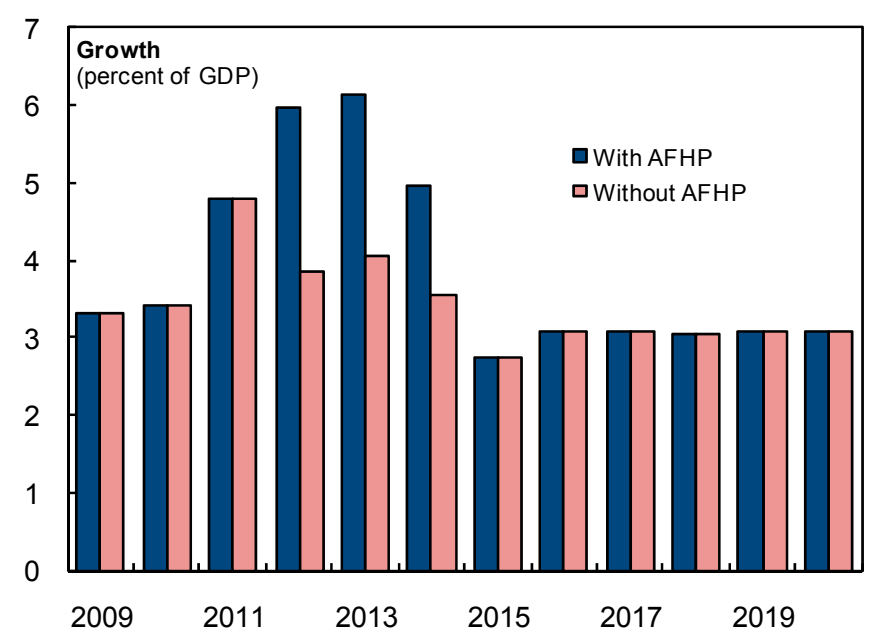
precise extent of the pass-through of these savings to the end-user would depend on the PPA and its impact on GPL's operational balance (see below).

- $\quad$ Balance of Payments: Imports are expected to increase between 2012 and 2014 as the FDI flows are used to purchase materials and equipment, widening the external current account deficit to some 16-18 percent of GDP. Once completed, the project is likely to result in a 20 to 25 reduction in fuel imports, as the GPL switches to sourcing its power needs from the AFHP. This would shield the GPL from volatile international oil prices. A key issue, however, is the extent of the displacement that AFHP can provide, as GPL would need to maintain backup

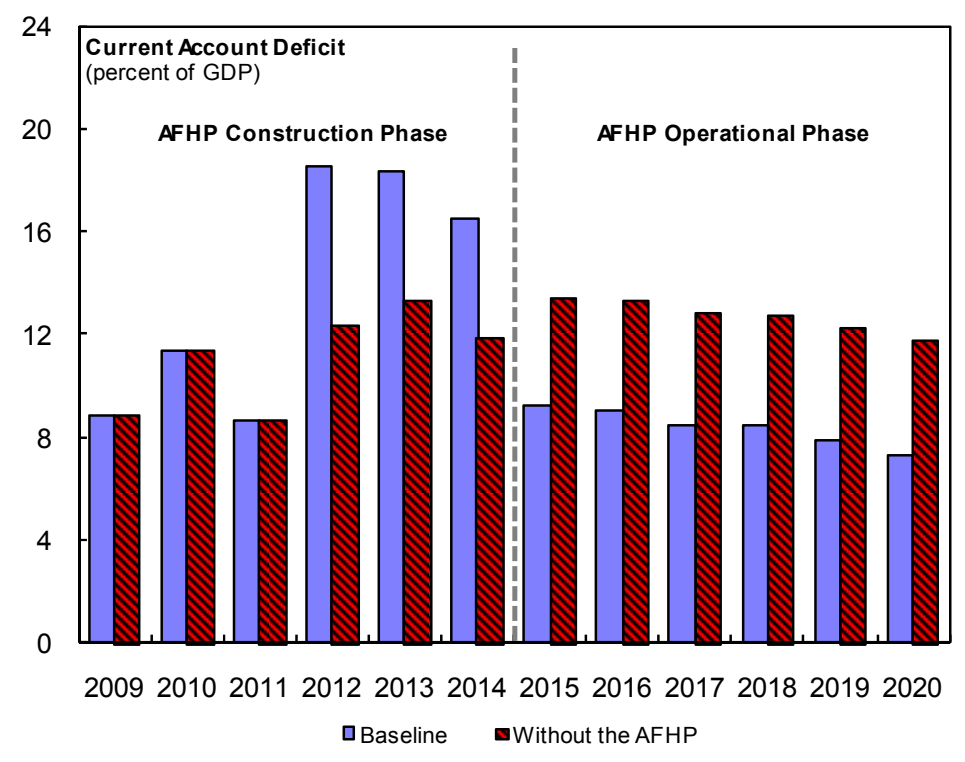
generation capacity, which increases with the size of its market, as private self generators purchase cheaper electricity from GPL and stop self generating.

- $\quad$ Fiscal Accounts: The impact on public finances during the construction stage of the AFHP should be minimal since the government will not participate in the construction 
process. Moreover, the private contractor will assume any cost overruns. In the event, however, that the government assumes the full obligations of the project, public debt to GDP ratio would rise by 30 percentage points. ${ }^{1}$

- In the baseline scenario, where electricity tariffs are unchanged; GPL's overall balance is projected to show a surplus of about 0.5 percent of GDP in 2015, the year AFHP would start operating.

- In the alternative scenario, with a tariff reduction of 20 percent offset by an increase in electricity consumption, GPL's overall balance (surplus) falls marginally, to 0.4 percent of GDP. Revenues would remain unchanged (unitary elasticity), and GPL's first payment to the private operator would be a bit higher than the cost of materials and supplies (largely oil imports) in the baseline scenario. ${ }^{2}$ The following table shows the impact on GPL's overall balance assuming different elasticities. In sum, in the alternative scenario, GPL's overall balance is likely to be between 0.0 and 0.4 percent of GDP. ${ }^{3}$

\footnotetext{
${ }^{1}$ In this case, the private contractor forsakes its obligations and its debt is assumed by the government; a fraction of the $\$ 100$ million annual payment made previously to the private contractor will now be used to service the debt.

${ }^{2}$ GPL's annual payment to the private contractor (initially over $\$ 100$ million but declining overtime) is financed with the collections GPL makes on domestic consumers (about $\$ 150$ million). Since the amount of electricity provided by the private contractor will exceed demand, it will allow GPL to increase its revenue stream over time despite lower tariffs.

${ }^{3}$ Note that a 10 percent increase in oil prices in the baseline scenario could reduce GPL overall balance to 0.2 percent of GDP and bringing about a hike of electricity tariffs for domestic consumers and a negative impact on the current account.
} 
Impact of AFHP on GPL Finances

(In millions of U.S. dollars, unless otherwise indicated)

\begin{tabular}{|c|c|c|c|c|}
\hline & \multicolumn{4}{|c|}{2015} \\
\hline & \multirow{2}{*}{ Baseline } & \multicolumn{3}{|c|}{ Alternative (AFHP): $20 \%$ tariff reduction } \\
\hline & & $e=-1.0$ & $e=-0.8$ & $e=-0.6$ \\
\hline Total receipts & 156.6 & 156.6 & 149.5 & 143.0 \\
\hline Payments & 129.7 & 134.1 & 134.1 & 134.1 \\
\hline Materials and supplies & 100.6 & & & \\
\hline GPL payment to AFHP Inc. & & 105.0 & 105.0 & 105.0 \\
\hline Current primary balance & 26.9 & 22.6 & 15.4 & 9.0 \\
\hline Interest & 0.7 & 0.7 & 0.7 & 0.7 \\
\hline Current balance & 26.2 & 21.9 & 14.8 & 8.3 \\
\hline Capital expenditure & 9.7 & 9.7 & 9.7 & 9.7 \\
\hline \multirow{3}{*}{$\begin{array}{l}\text { Overall balance } \\
\text { (in percent of GDP) }\end{array}$} & 16.6 & 12.2 & 5.1 & -1.4 \\
\hline & 0.5 & 0.4 & 0.2 & 0.0 \\
\hline & \multicolumn{2}{|c|}{$2015-30$} & & \\
\hline Overall balance (in percent of GDP) & 0.5 & 1.0 & & \\
\hline
\end{tabular}

Source: Fund staff estimates.

e: elasticity

- $\quad$ Over the long term, as GPL payments to the private contractor decline, demand for electricity rises, the impact on the fiscal accounts is positive; GPL overall balance in 2015-30 is about 1 percent of GDP in the alternative scenario compared with 0.5 percent in the baseline scenario.

- An additional benefit of the project is the potential for additional revenues to the government from the sale of carbon credits from the AFHP of approximately US\$10 million annually. 


\section{AtTachment III. GuYana: Sustainability of The National InSURAnCE Scheme}

The mismatch between pension benefits and contributions, and weak reserve management threatens the sustainability of the National Insurance Scheme (NIS). A recent actuarial report has recommended a set of urgent parametric reforms to restore financial viability and reduce fiscal contingencies.

1. The NIS is a defined-benefit pension arrangement. It was established in 1960, with membership open to private and public sector workers, and levies contributions that are low relative to benefits (Table 1 ). The NIS pension system covers only $31 \frac{1}{2}$ percent of the employed population. Apart from the NIS, there is a non-contributory, defined benefit, pension scheme for permanent public servants, paid from the government's budget.

\section{The finances of the NIS are unsustainable under current parameters (Table 2). ${ }^{1}$}

Projections show that after 2011 the NIS will shift from small surpluses to growing deficits, under the following trends and developments:

- $\quad$ The ageing of the participating population, as the number of contributors per pensioner would fall from 8 in 2006 to 2 by the year 2056;

- $\quad$ A relatively high minimum pension, given the low wage environment (the minimum pension is equivalent to approximately 50 percent of the minimum wage in the public sector, or 34 percent of average insurable earnings);

- $\quad$ Large and growing contribution arrears - GUY\$300 million in 2010. Delays in the court system have also denied resources to the NIS (there are currently 90 outstanding court cases worth GUY\$189 million and approximately 189 writs worth GUY\$66.4 million);

- $\quad$ Growing NIS contribution evasion by workers, employers, and the self employed;

- $\quad$ A shortfall of 7.1 percent in the contribution rate required to fund benefits up to 2056 . The actual contribution rate, 13 percent, is too low relative to the required contribution rate (20 percent) that would be required to meet the cost of the benefits package up to 2056;

- $\quad$ The size and growth of informal sector activities;

- A relatively low retirement age (60 years);

\footnotetext{
${ }^{1}$ The Seventh Actuarial Review of NIS, done for 2006 and issued in 2008, estimates an actuarial deficit of 130 percent of GDP.
} 
- Generous growth of annual pensions benefits, driven by the minimum pension adjustment factor, which is not linked to contributions; High administrative costs (equivalent to about 15 percent of contribution income, or 0.4 percent of GDP).

3. A new development, not covered by the actuarial report, is the impact of the CLICO debacle. The NIS has an investment of the approximately 18.6 percent of its total assets, or 1.3 percent of GDP, in the CLICO conglomerate (currently under judicial management), for which it has been given a guarantee by the government.

\section{In 2008, the $7^{\text {th }}$ Actuarial Review made a number of reform recommendations to restore financial balance and relevance to the NIS.}

- $\quad$ Maintaining the defined benefit structure, but adjusting key parameters — such as gradually raising the retirement age to 65 years, bringing it in line with current life expectancy (66 1/2 years); and raising the contribution rate;

- $\quad$ Adopting a specific funding objective over the long-term, such as a reserve that is one or two times annual expenditures, and adjusting contribution rates to achieve it;

- $\quad$ Balancing any increases in old-age pensions benefits with adjustments in other aspects of the provisions that will create savings;

- $\quad$ Removing all gender differences from survivors benefit provisions and allowing children of deceased insured to easily qualify for pensions;

- Improving administrative efficiency and effectiveness;

- Investing assets of the NIS according to the prudential investment framework and the selected funding objectives;

- $\quad$ Publishing the report of the $7^{\text {th }}$ actuarial review and the reform committee and the annual financial statements.

5. The authorities have taken some actions. First, in 2006, an NIS Reform Committee was established to provide guidelines on the way forward. Although its recommendations have not been implemented, the NIS has introduced some changes, including: (a) gender equality in the payment of benefits; (b) improved monitoring to ensure that beneficiaries meet the qualifying conditions; and (c) computerization of NIS' records and processes. To fully restore financial balance to the NIS, other important actions, such as raising the retirement age, otherwise restraining the growth of benefits expenditure and increasing the contribution rates over time would have to be taken. 
Appendix Table 1. Guyana: Key features of the National Insurance Scheme

Contribution rate

Minimum contribution period

Retirement age

Replacement rate
Total of 13 percent

5.2 percent of earning paid by employee

7.8 percent paid by the employer

15 years

60 years of age

Up to 60 percent of average earnings

in the last three years

Sources: Seventh Actuarial Review of the National Insurance Scheme

Appendix Table 2. Guyana: Summary Operations of the National Insurance Scheme

\begin{tabular}{|c|c|c|c|c|c|c|c|c|c|}
\hline & 2010 & 2011 & 2012 & 2013 & 2014 & 2015 & 2020 & 2025 & 2030 \\
\hline \multicolumn{10}{|c|}{ (In Billions of Guyana Dollars) } \\
\hline Income & 11.3 & 11.3 & 11.4 & 12.0 & 12.5 & 13.1 & 16.2 & 19.6 & 22.7 \\
\hline Contributions & 9.7 & 9.8 & 10.2 & 10.8 & 11.4 & 12.0 & 15.6 & 20.3 & 26.4 \\
\hline Investment income & 1.6 & 1.5 & 1.1 & 1.1 & 1.1 & 1.1 & 0.6 & -0.8 & -3.7 \\
\hline Other & 0.0 & 0.0 & 0.0 & 0.0 & 0.0 & 0.0 & 0.0 & 0.1 & 0.1 \\
\hline Expenditures & 10.6 & 10.7 & 11.4 & 12.2 & 13.1 & 14.0 & 19.8 & 28.0 & 39.6 \\
\hline Payment of benefits & 9.3 & 9.3 & 9.9 & 10.7 & 11.5 & 12.3 & 17.6 & 25.2 & 35.9 \\
\hline Other current expenditures & 1.3 & 1.4 & 1.4 & 1.5 & 1.6 & 1.7 & 2.2 & 2.8 & 3.7 \\
\hline Current surplus or deficit (-) & 0.7 & 0.7 & $\mathbf{0 . 0}$ & -0.2 & -0.5 & -0.9 & -3.6 & -8.4 & -16.9 \\
\hline Capital expenditure & 0.1 & 0.1 & 0.1 & 0.1 & 0.1 & 0.1 & 0.2 & 0.2 & 0.3 \\
\hline Overall surplus or deficit (-) & 0.6 & 0.5 & -0.1 & -0.4 & -0.7 & -1.0 & -3.7 & -8.7 & -17.2 \\
\hline \multicolumn{10}{|c|}{ (Annual percent change) } \\
\hline Income & 11.6 & -0.1 & 0.8 & 4.8 & 4.7 & 4.6 & 4.2 & 3.5 & 2.7 \\
\hline Contributions & 8.9 & 0.6 & 4.9 & 5.4 & 5.4 & 5.4 & 5.4 & 5.4 & 5.4 \\
\hline Investment income & 32.0 & -3.7 & -25.7 & -0.4 & -1.5 & -3.0 & -20.3 & 93.1 & 25.7 \\
\hline Other & 2.2 & -24.9 & 4.9 & 5.4 & 5.4 & 5.4 & 5.4 & 5.4 & 5.4 \\
\hline Expenditures & 12.7 & 0.6 & 6.7 & 7.1 & 7.1 & 7.2 & 7.2 & 7.2 & 7.2 \\
\hline Payment of benefits & 13.7 & 0.0 & 6.9 & 7.4 & 7.4 & 7.4 & 7.4 & 7.4 & 7.4 \\
\hline Other current expenditures & 6.1 & 4.4 & 4.9 & 5.4 & 5.4 & 5.4 & 5.4 & 5.4 & 5.4 \\
\hline Current surplus or deficit (-) & -1.9 & -9.7 & -94.9 & -779.6 & 133.1 & 65.9 & 23.5 & 16.7 & 13.9 \\
\hline Capital expenditure & 71.4 & -9.7 & 4.9 & 5.4 & 5.4 & 5.4 & 5.4 & 5.4 & 5.4 \\
\hline Overall surplus or deficit (-) & -9.7 & -9.7 & -114.9 & 329.4 & 88.8 & 54.2 & 22.5 & 16.4 & 13.8 \\
\hline \multicolumn{10}{|c|}{ (In percent of GDP) } \\
\hline Income & 2.5 & 2.3 & 2.1 & 2.0 & 1.9 & 1.8 & 1.6 & 1.3 & 1.1 \\
\hline Contributions & 2.1 & 2.0 & 1.9 & 1.8 & 1.7 & 1.7 & 1.5 & 1.3 & 1.3 \\
\hline Investment income & 0.4 & 0.3 & 0.2 & 0.2 & 0.2 & 0.2 & 0.1 & -0.1 & -0.2 \\
\hline Other & 0.0 & 0.0 & 0.0 & 0.0 & 0.0 & 0.0 & 0.0 & 0.0 & 0.0 \\
\hline Expenditures & 2.3 & 2.2 & 2.1 & 2.0 & 2.0 & 1.9 & 1.9 & 1.9 & 1.9 \\
\hline Payment of benefits & 2.0 & 1.9 & 1.8 & 1.8 & 1.7 & 1.7 & 1.7 & 1.7 & 1.7 \\
\hline Other current expenditures & 0.3 & 0.3 & 0.3 & 0.2 & 0.2 & 0.2 & 0.2 & 0.2 & 0.2 \\
\hline Current surplus or deficit (-) & 0.2 & 0.1 & 0.0 & 0.0 & -0.1 & -0.1 & -0.3 & -0.6 & -0.8 \\
\hline Capital expenditure & 0.0 & 0.0 & 0.0 & 0.0 & 0.0 & 0.0 & 0.0 & 0.0 & 0.0 \\
\hline Overall surplus or deficit (-) & 0.1 & 0.1 & 0.0 & -0.1 & -0.1 & -0.1 & -0.4 & -0.6 & -0.8 \\
\hline
\end{tabular}

Sources: NIS, and IMF staff estimates 


\section{Attachment IV. GuYana: Financial Sector Stability and Reforms-Progress SINCE THE FSAP}

The authorities are pressing ahead with financial sector reforms, broadening the perimeter of financial regulation and the supervisory authority of the central bank. Prudential sector indicators have improved, but there is a need for continued vigilance.

\section{The authorities' financial reform strategy has focused on two key elements:}

(i) strengthening the regulatory framework; and (ii) expanding the supervisory perimeter of the central bank to cover non-bank financial institutions. These reforms, along with robust economic activity, have led to an improvement in financial stability indicators. ${ }^{1}$

2. Progress on implementing the reform plans has been commendable. Of the 26 planned reforms, 12 have already been fully implemented - 5 of 13 under the short-term reform plans, 7 of 13 under the long-term reform plans. Of the remaining 8 reform plans, substantial progress has been made on most of the requirements (Table 1).

\section{Specific attention has been given to strengthening the banking sector and} widening the regulatory perimeter. The authorities have issued new guidelines on risk management (including on related-party credit), which are being supplemented with strengthened banking supervision and a tightening in regulations on related-party credit and large exposures. In 2010, legislation was passed to bring the supervision of the mortgage bank (NBS) under the central bank. The authorities have also signaled their intentions to strengthen the regulatory framework for the insurance and credit union sectors and to place them under the jurisdiction of the Bank of Guyana.

4. Efforts are also being made to improve credit market conditions. As part of Caricom wide program to support the development of the credit market and improve lending conditions, the authorities passed the credit bureau act. Guidelines for their operations are being worked out.

\section{As a result of the ongoing reforms and vigilance, financial sector risks appear} contained. In the banking sector, the nonperforming loan ratio fell to 6.0 percent in September 2010, from 8.3 percent at end-2009. Banks remain liquid and provisioning levels have improved, albeit from a relatively low base. Although loan concentration and relatedparty lending to total loans remain a concern, these have declined marginally in 2010 , to about 29.8 percent and 3.8 percent, respectively from 35.5 percent and 4.5 percent

\footnotetext{
${ }^{1}$ The financial sector in Guyana comprises six commercial banks and a host of non-bank financial institutions. Three commercial banks are foreign owned, but all non-banks are locally owned. The non-bank financial institutions (NBFI) include depository and non-depository licensed and unlicensed financial institutions. The following institutions comprise the NBFI: The New Building Society, Trust Companies, Finance Companies, Asset management Companies, Pension Schemes, and Domestic Insurance companies.
} 
respectively at end-2009. ${ }^{2}$ Meanwhile, payouts to policy holders of CLICO-Guyana are underway, in line with the authorities' plans to minimize the fiscal costs.

\section{The authorities should quickly conclude the implementation of the outstanding}

reforms. Notwithstanding the improvement in banking sector ratios, a sudden downward shift in the business outlook is possible, if commodity prices were to fall suddenly, under performance in the sugar sector were to become entrenched, or fiscal risks associated with the AFHP emerge. Against this background, continued actions to fully and speedily implement all of the reforms, should help Guyana put the financial system in a stronger position to support sustainable growth.

\footnotetext{
${ }^{2}$ Bank of Guyana has recently changed the methodology for measuring loan concentration, from "top 20 borrowers to total loans" to "top 20 borrowers to total exposure". Using this measure, loan concentration declined to 23.4 percent in September 2010 from 26 percent in December 2009.
} 
Table 1. Guyana: Proposed Financial Sector Reforms: Status of Implementation

\begin{tabular}{|c|c|c|}
\hline & THE MAIN PROPOSED REFORMS & Status \\
\hline & SHORT-TERM OPERATIONAL MEASURES & \\
\hline \multirow{5}{*}{ 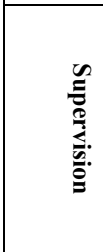 } & $\begin{array}{l}\text { - Tighten the large exposures limit and definition of connected lending- Amend the Financial Institutions Act (FIA) to tighten large } \\
\text { exposures limit, and definition of related party lending, as well as to introduce a time limit for the resolution of bank reorganizations. }\end{array}$ & $\begin{array}{l}\text { No plans at this time to amend the Single Borrower limits. The other } \\
\text { matters are under consideration. }\end{array}$ \\
\hline & - Improve bank reporting forms, analyze the financial performance of individual banks, and place more emphasis on trend analysis & Done. \\
\hline & $\begin{array}{l}\text { - Change the human resources approach of staff development and rotation in Bank of Guyana (BOG) to account for short staff } \\
\text { tenure }\end{array}$ & $\begin{array}{l}\text { Staff complement increased in Bank Supervision Department (BSD). } \\
\text { Current staffing is } 25 \text { with } 2 \text { being recruited in } 2010 \text {. }\end{array}$ \\
\hline & - Publicly disclose the financial reports of all Licensed Financial Institutions (LFIs) and insurers & Done for LFI's. Arrangement being made for publication by insurers. \\
\hline & - Increase the capacity of insurance supervision and fully monitor all insurer activities. & $\begin{array}{l}\text { Insurance Supplementary provisions Act passed in 2009, and the supervision } \\
\text { of the insurance sector is now under the purview of the Bank of Guyana. }\end{array}$ \\
\hline \multirow{5}{*}{ 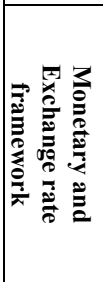 } & $\begin{array}{l}- \text { Greater public dissemination by the BOG of more timely information including through the production of mid-yearly policy } \\
\text { statement and greater use of internet }\end{array}$ & Done. \\
\hline & - Separate the treasury accounts at BOG that are used for liquidity and for government cash purposes & Discussions ongoing on the appropriate framework to achieve this objective. \\
\hline & - Start regular consultations between BOG and the Ministry of Finance (MOF) on liquidity and debt management & $\begin{array}{l}\text { Initial consultations already started between MOF and BOG. Agreed to } \\
\text { have more regular meetings (at least quarterly) led by the Office of the } \\
\text { Budget, Ministry of Finance }\end{array}$ \\
\hline & - Formulate a crisis-management framework. & Done. \\
\hline & - Set up a loss-sharing arrangement for the large-value transfer system & $\begin{array}{l}\text { In progress. Currently implementing the recommendations of } \\
\text { consultancy on the matter }\end{array}$ \\
\hline \multirow{3}{*}{ 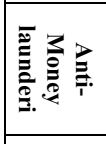 } & - Consent to finalization of the CFATF mutual evaluation report prepared by Caribbean Financial Action Task Force (CFATF). & Done. \\
\hline & - Amend the Money laundering Prevention Act. & Done. \\
\hline & - Increase the capacity of the Financial Intelligence Unit (FIU). & $\begin{array}{l}\text { Ongoing within the context of the Inter-American Development Bank } \\
\text { (IDB) Financial Sector Reform Program III. }\end{array}$ \\
\hline & LONG-TERM STRUCTURAL REFORM & \\
\hline \multirow{8}{*}{ 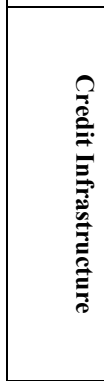 } & • Establish a Credit Bureau. & $\begin{array}{l}\text { Credit Bureau Act has been passed in parliament. Regulations for its } \\
\text { implementation are being prepared. }\end{array}$ \\
\hline & - Enhance the capacity of the company registrar to enforce company disclosure rules. & $\begin{array}{l}\text { Business registration has been computerized and incorporated the } \\
\text { records into the Deeds Registry in } 2009 \text {. }\end{array}$ \\
\hline & - Complete the Land Title Program and establish a Single Lands Registry. & Done. \\
\hline & - Amend the Companies Act to strengthen creditor rights. & Commercial Court established \\
\hline & - Examine potential for further developing financial instruments that transfer the ownership of the pledged assets such as leasing and collateral trusts. & Done. \\
\hline & - Encourage developmental partnerships between commercial banks and Micro Financial Institutions (MFIs). & Done. \\
\hline & - Support automation of payment and transfer mechanisms of pensions and public assistance through the post office corporation. & $\begin{array}{l}\text { Phased approach to automation adopted. Significant progress made in } \\
\text { automating payment of salaries and pension of the public service through } \\
\text { the banking system. }\end{array}$ \\
\hline & - Require small scale institutions to register with the BOG for purposes of monitoring (long term). & Done. \\
\hline \multirow{5}{*}{ 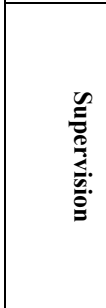 } & $\begin{array}{l}\text { - Introduce non-zero risk weights and/or provisions on banks foreign security investments in line with their respective sovereign } \\
\text { risk ratings. }\end{array}$ & $\begin{array}{l}\text { Under consideration pending the proposed harmonized position of the } \\
\text { Caribbean group of Banking Supervisors. }\end{array}$ \\
\hline & $\begin{array}{l}- \text { Develop and issue minimum and consistent risk management supervisory standards, including risk governance and borrower } \\
\text { appraisal techniques. }\end{array}$ & Done. \\
\hline & - Bring the New Building Society (NBS) under the formal supervision of the BOG. & Done. \\
\hline & $\begin{array}{l}\text { - Enhance coordination and sharing of information across supervisory agencies by eliminating legal obstacles and explicitly } \\
\text { allowing for it in the law. }\end{array}$ & $\begin{array}{l}\text { Significant progress made with the consolidation of supervision under } \\
\text { the Bank of Guyana (banks, insurance, money transfer agencies and } \\
\text { cambios). Addressing the sharing of information with the Securities } \\
\text { Council and the regulator of credit Unions is being undertaken. }\end{array}$ \\
\hline & - Improve communication by holding regular (at least quarterly) meetings between the BOG and the Guyana Association of Banks (GAB). & Done. \\
\hline
\end{tabular}

Sources: Bank of Guyana; and Fund staff estimates. 


\title{
INTERNATIONAL MONETARY FUND
}

GUYANA

\section{Staff Report for the 2010 Article IV Consultation-Informational Annex}

\author{
Prepared by the Western Hemisphere Department
}

January 5, 2011

Contents

Page

Appendices

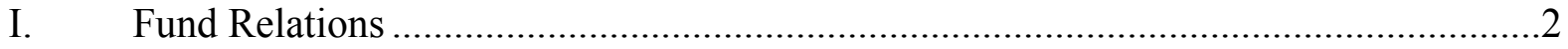

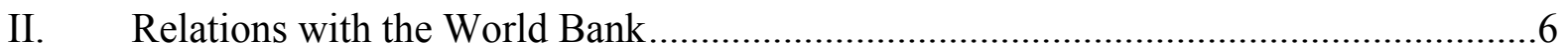

III. Relations with the Inter-American Development Bank ...............................................

IV. Relations with the Caribbean Development Bank ……............................................10

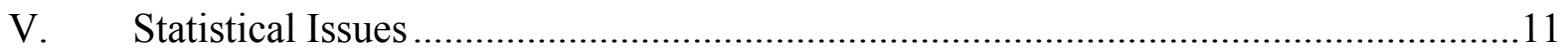




\section{APPENDIX I. GUYANA: FUND RELATIONS}

(As of November 30, 2010)

I. SDR Department Membership Status: Joined: September 26, 1966; Article VIII.

II. General Resources Account:

Quota

Fund holdings of currency

Reserve Tranche Position

Lending to the Fund

Notes Issuance

Holdings Exchange Rate

III. SDR Department:

Net cumulative allocation

Holdings

IV. Outstanding Purchases and Loans:

ECF Arrangements

V. Latest Financial Arrangements:

$\begin{array}{ccccc}\text { Type } & \begin{array}{c}\text { Date of } \\ \text { Arrangement }\end{array} & \begin{array}{c}\text { Expiration } \\ \text { Date }\end{array} & \begin{array}{c}\text { Amount Approved } \\ \text { (SDR Million) }\end{array} & \begin{array}{c}\text { Amount Drawn } \\ \text { (SDR Million) }\end{array} \\ \text { ECF }^{\mathbf{1}} & \begin{array}{c}\text { Sep 20,2002 } \\ \text { ECF }^{\mathbf{1}}\end{array} & \text { Sep 12, 2006 } & 54.55 & 54.55 \\ \text { ECF }^{1 /} & \text { Jul 15, 1998 } & \text { Dec 31, 2001 } & 53.76 & 24.88 \\ & \text { Jul 20,1994 } & \text { Apr 17, 1998 } & 53.76 & 53.76\end{array}$

1/ Formerly PRGF

VI. Projected Payments to Fund ${ }^{2 /}$

(SDR Million; based on existing use of resources and present holdings of SDRs):

Principal

$\begin{array}{lcccc}\underline{5} \text { Fo10 } & \underline{2011} & \underline{2012} & \underline{2013} & \underline{2014} \\ & 4.64 & \underline{7.41} & \underline{7.41} & \underline{0.32} \\ & \underline{\mathbf{4 . 9 5}} & \underline{\mathbf{7 . 8 0}} & \underline{\mathbf{7 . 7 8}} & \underline{\mathbf{7 . 7 6}}\end{array}$

Total

${ }^{2 /}$ When a member has overdue financial obligations outstanding for more than three months, the amount of such arrears will be shown in this section.
SDR Million

90.90

90.90

0.00

\%Allocation

87.09

100.00

1.33

1.52

SDR Million

36.13

\%Quota

39.75
$\%$ Quota

100.00

0.00
Charges/Interest

Jul 15, 1998

Apr 17, 1998

53.76

53.76 


\section{Implementation of HIPC Initiative:}

I. Commitment of HIPC assistance

Original Enhanced

Framework Framework Total

Decision point date

Dec 1997 Nov 2000

Assistance committed by all creditors (US\$ Million) ${ }^{1 /}$

256.40

334.50

Of which:

IMF assistance (US\$ million)

34.50

40.00

(SDR equivalent in millions)

25.56

31.07

Completion point date

May 1999 Dec 2003

II. Disbursement of IMF assistance (SDR Million)

Assistance disbursed to the member

25.56

31.07

56.63

Interim assistance

15.35

15.35

Completion point balance

25.56

15.73

41.29

Additional disbursement of interest income ${ }^{2 /}$

2.96

2.96

Total disbursements

25.56

34.03

59.59

${ }^{1 /}$ Assistance committed under the original framework is expressed in net present value (NPV) terms at the completion point, and assistance committed under the enhanced framework is expressed in NPV terms at the decision point. Hence these two amounts cannot be added.

${ }^{2 /}$ Under the enhanced framework, an additional disbursement is made at the completion point corresponding to interest income earned on the amount committed at the decision point but not disbursed during the interim period.

\section{Implementation of Multilateral Debt Relief Initiative (MDRI):}

I. MDRI-eligible debt (SDR Million) ${ }^{1 /}$

45.06

Financed by: MDRI Trust

Remaining HIPC resources

II. Debt Relief by Facility (SDR Million)

\section{Eligible Debt}

$\frac{\text { Delivery }}{\text { Date }}$

January 2006

\section{$\underline{\text { GRA }}$}

$\mathrm{N} / \mathrm{A}$
PRGT

45.06 $\underline{\text { Total }}$

45.06

${ }^{1 /}$ The MDRI provides 100 percent debt relief to eligible member countries that qualified for the assistance. Grant assistance from the MDRI Trust and HIPC resources provide debt relief to cover the full stock of debt owed to the Fund as of end-2004 that remains outstanding at the time the member qualifies for such debt relief.

IX. Implementation of Post-Catastrophe Debt Relief (PCDR): Not Applicable X. Previous Decisions and Article IV Consultation Cycle: 
a. On December 18, 2003, the Executive Board determined that Guyana had reached the completion point under the enhanced HIPC Initiative (IMF Country Report No. 04/123).

b. On February 27, 2009, the Executive Board concluded the 2008 Article IV consultation.

c. On March 17, 2010, the Executive Board concluded the 2009 Article IV consultation (IMF Country Report No. 10/292). Guyana is on a 12-month cycle for Article IV consultations.

\section{Safeguard Assessments}

An updated safeguards assessment of the Bank of Guyana (BoG), related to the then expected PRGF arrangement, was completed in May 2007. The assessment found that the BoG has taken steps to improve its safeguards since the previous assessment in 2003. In particular, compliance with International Financial Reporting Standards (IFRS) in the annual financial statements have improved, although certain disclosures still do not meet requirements, and a new internal audit charter and associated practices have been adopted. The assessment recommended involvement of an audit firm with experience in International Standards on Auditing and IFRS in future BoG external audits to address professional capacity constraints in Guyana, and reconstitution of the Board of Directors to address governance shortcomings. The latter action was completed in May 2007.

\section{Exchange Rate Arrangement}

Guyana has accepted the obligations of Article VIII-Section 2, 3, and 4-and maintains an exchange system that is free of restrictions on the making of payments and transfers for international transactions, with the only exception of certain exchange restrictions for the preservation of national and international security. Guyana's de jure exchange rate regime is floating. Guyana's de facto exchange rate regime is classified as a stabilized arrangement. The BoG conducts transactions on the basis of the weighted average quotations of the three largest dealers in the exchange market. The currency of Guyana is the Guyana dollar. The exchange rate was G\$204 per U.S. dollar on October 31, 2010.

\section{ROSC, FSAP, EPA Participation}

a. A fiscal ROSC was undertaken in July 2002.

b. A WB/IMF FSAP took place in November 2005 and concluded in September 2006.

c. Ex-Post Assessment findings were discussed with the authorities in June 2006 and concluded on October 23, 2006. 
XIV. Technical Assistance

\section{Fiscal Affairs Department}

May 2006

Develop program to prepare for VAT implementation.

Aug. 2006

Monitor preparation for VAT implementation.

Sep. 2006

Monitor preparation for VAT implementation.

Dec. 2006

Monitor preparation for VAT implementation.

Dec. 2006

Update progress in strengthening the public expenditure management system.

Jun. $2007 \quad$ VAT implementation follow-up.

Apr. 2008 CARTAC (budget management).

\section{Monetary and Capital Markets Department}

Mar. 2009

CARTAC (Regulation of market risk capital charge)

Oct. 2009

CARTAC (Development of stress-testing)

Nov. 2009

CARTAC (Risk-based supervision training)

Dec. 2009

CARTAC (Development of stress-testing)

June 2010

CARTAC (Credit bureau-related regulation and training)

\section{Statistics Department}

Apr. 2005

Apr. 2005

Apr. 2006

Apr. 2007

Oct. 2007

Nov. 2007

June 2009

June 2009

June 2009

June 2009

Aug. 2009

Aug. 2009

Oct. 2009

Nov. 2009

Jan. 2010
Monetary and financial statistics, follow up.

Government Finance Statistics.

CARTAC (national accounts)

CARTAC (national accounts)

CARTAC: LTE: Improvement of Annual GDP Estimates-Review of Survey Instruments.

CARTAC (Macroeconomic Statistics for Economists course)

CARTAC (Training in Balance of Payments)

CARTAC (Needs assessment on National Accounts)

CARTAC (CPI revision of Georgetown index)

CARTAC (Training in CPI methods and procedures)

CARTAC (National accounts rebasing)

CARTAC (CPI revision of Georgetown index)

CARTAC (National accounts rebasing)

CARTAC (CPI revision of Georgetown index)

CARTAC (National accounts rebasing)

\section{Legal Department}

May 2005

Aug. 2005

Sep. 2005

Apr. 2006

Aug. 2006
Tax legislation.

VAT regulations.

Update AML/CFT legislation.

Income-tax regulations.

Tax drafting.

\section{Resident Representative}

The office was closed in end-January 2009. 


\section{APPENDIX II. GUYANA: RELATIONS WITH THE WORLD BANK GROUP}

(As of October 25, 2010)

The Guyana portfolio of IDA-financed projects is comprised of two projects totaling US\$15.5 million; Improving Teacher Education (US\$4.2 million) and Water Sector Consolidation (US\$11.3 million). In addition, a Trust Fund portfolio totaling US\$16 million includes: (i) the Education for All/Fast Track Initiative (EFA-FTI) program supported by the FTI Catalytic Fund (US\$12.2 million); (ii) the Global Environment Facility (GEF) grant for the Conservancy Adaptation Project (US\$3.8 million). One Grant (Recipient-Executed) is in the pipeline - Guyana - FCPF Readiness Preparation Grant (seed grant US\$200K, to be followed later by a US\$3 million preparation grant).

The most recent CAS (2009-2012), discussed by the Board of Executive directors on May 26, 2008, included two new lending projects: (i) the Community non-Timber Forest Uses Project (US\$5 million); and (ii) Improving Teacher Education (US\$4.2 million) already effective. It also included three analytical activities: On-demand economic monitoring and just-in-time analysis; Agriculture Risk Insurance, and Safety Nets.

\section{World Bank Support to the Climate Change Agenda}

\section{Adaptation}

The Bank supports the adaptation to climate change through two projects: first, the GEF financed "Mainstreaming Adaptability to Climate Change" (US\$5million) for CARICOM member states that has served as a platform to promote mainstreaming of climate change considerations and strengthen climate modeling capacity; second, the Conservancy Adaptation Project (US\$3.5million), which began operating in January 2008, to help reduce the vulnerability to catastrophic flooding from a rise in sea level.

\section{Mitigation}

The Forest Carbon Partnership Facility (FCPF) aims to reduce emissions through the conservation and sustainable management of existing carbon sinks in return for financial transfers. ${ }^{1}$ Guyana was one of the first countries to submit a Readiness Preparation Proposal to the FCPF in June 2009. A seed grant is being processed for the Readiness Preparation Proposal, and another grant will be available for its implementation.

More generally, the Country Assistance Strategy identified four areas of support to Guyana's forests: (i) The FCPF; (ii) An IDA non-timber community forest project; (iii) A JSDF grant to support community-based enterprises in the hinterland; and (iv) A possible GEF grant. However, the Government recently indicated that it intends to finance the community

\footnotetext{
${ }^{1}$ The Kyoto Protocol (2008-2012) does not include Forest Conservation and Avoiding Deforestation.
} 
forestry project through the newly-established Guyana REDD+ Investment Fund (of which the Bank is the Trustee), and to re-focus the IDA envelope on tertiary education with a focus on environment and climate change.

The Bank also supports Guyana's climate mitigation efforts through the Skeldon Bagasse Cogeneration Project: This project is not operational at this time because the Emission Reductions (ER) have not yet begun. ER will start when a power-purchasing agreement is signed with the Guyana Power and Light for export of bagasse-generated power to the grid.

\section{Financial Relations}

Statement of World Bank Projects

(In millions of U.S. dollars, as of October 25, 2010)

\begin{tabular}{|l|c|c|c|}
\hline Operation & $\begin{array}{c}\text { Original } \\
\text { Principal }\end{array}$ & Available $^{\mathbf{1}}$ & Disbursed $^{\mathbf{1}}$ \\
\hline $\begin{array}{l}\text { GEF Conservancy Adaptation Project } \\
\text { (grant) }\end{array}$ & 3.8 & 3.1 & 0.7 \\
\hline $\begin{array}{l}\text { GY (CRL) Water Sector Consolidation } \\
\text { Project (loan) }\end{array}$ & 11.3 & 0.4 & 11.1 \\
\hline $\begin{array}{l}\text { Education for All Fast Track Initiative } \\
\text { (grant) }\end{array}$ & 12.2 & 8.6 & 24.3 \\
\hline Improving Teacher Education (loan) & 4.2 & 4.2 & 0 \\
\hline Total & $\mathbf{3 1 . 5}$ & $\mathbf{1 6 . 3}$ & $\mathbf{3 6 . 1}$ \\
\hline
\end{tabular}

1/ Amounts may not add up to Original Principal due to changes in the SDR/US exchange rate since signing.

Disbursements and Debt Service

(Fiscal Year ending November 2010)

\begin{tabular}{|l|c|c|c|c|c|c|c|c|c|c|}
\hline & $\mathbf{2 0 0 1}$ & $\mathbf{2 0 0 2}$ & $\mathbf{2 0 0 3}$ & $\mathbf{2 0 0 4}$ & $\mathbf{2 0 0 5}$ & $\mathbf{2 0 0 6}$ & $\mathbf{2 0 0 7}$ & $\mathbf{2 0 0 8}$ & $\mathbf{2 0 0 9}$ & $\begin{array}{c}\mathbf{2 0 1 0} \\
*\end{array}$ \\
\hline $\begin{array}{l}\text { Total } \\
\text { disbursements }\end{array}$ & 7.0 & 7.5 & 6.2 & 20.9 & 3.6 & 2.5 & 12.3 & 4.6 & 7.8 & 5.8 \\
\hline Repayments & 5.1 & 3.8 & 5.7 & 4.9 & 3.5 & 3.9 & 0.1 & 0.1 & 0.1 & 32.4 \\
\hline Net disbursements & 2.0 & 3.8 & 0.6 & 16.0 & 0.1 & -1.4 & 12.2 & 4.4 & 7.7 & -26.6 \\
\hline Interest and fees & 2.0 & 1.8 & 1.7 & 1.8 & 1.9 & 1.7 & 0.1 & 0.1 & 0.1 & 10.0 \\
\hline
\end{tabular}

*July - November 2010 


\section{APPENDIX III. GUYANA: RELATIONS WITH THE INTER-AMERICAN DEVELOPMENT BANK}

(As of November 30, 2010)

The IDB is Guyana's major source of multilateral concessional financing with projects spanning most sectors. Since 1977, the Bank has approved loans amounting to US\$1225.9 million. Outstanding debt stands at US\$268.9 million (excluding undisbursed HIPC debt relief, but after MDRI) while the undisbursed portfolio totals US\$195.1 million. The IDB cancelled US\$356.5 million (principal) of Guyana's outstanding debt effective January 2007. A further US\$35 million was cancelled from some loans in execution, which were undisbursed. Lending to Guyana continues to be concessional (but with a lower grant element than before), consisting of a 50-50 blend of resources from the IDB's Fund for Special Operations and Ordinary Capital. The annual envelope of allocations is US\$41.5 million for 2011 and 2012 each.

The Board of Directors approved the IDB Country Strategy with Guyana 2008-2012 in January 2009. According to the new Strategy, the IDB and the GoG will make strategic interventions, while maximizing future financial allocations that increase the productivity of human inputs for all, promote entrepreneurship, strengthen the private sector, buffer the negative impacts of the economic transformation on the marginalized sectors of society, and create opportunities for key infrastructure improvements in partnership with the national and international private sector. The baseline scenario in the strategy envisages total lending of US\$113 million according to the following pillars: (i) strategic infrastructure investment, (ii) enhanced competitiveness, and (iii) social development for growth. By the end of 2010, US\$104.2 million were approved within the framework of the new Country Strategy.

The large existing IDB portfolio, aligned with the above pillars and future allocations, is a principal foundation of this new strategy. Consequently, future initiatives will augment the positive, IDB-financed work already underway in Guyana. The IDB has moved actively toward the use of country systems while ensuring a timely and efficient delivery of the important stock of projects in execution. Current activities focus on improving financial management and institutional capacity of line ministries to execute projects directly in addition to strengthening the Office of the Auditor General. Country capacity will dictate the pace of this transition in addition to the measures needed to improve the execution and disbursement of the portfolio and the achievement of the development objectives, both at the strategic and project level.

In 2010, the IDB approved four projects totaling US\$36.5 million: East Bank Demerara Four Lane (US\$20 million), Georgetown Sanitation Improvement Program (US\$9.5 million), Georgetown Solid Waste Management Program-Supplementary Financing (US\$2 million), and the Financial Sector Reform III (US\$5 million). The 2011 NSG pipeline (totaling US\$41.5 million) consists of three operations: EBD Four Lane Extension South of Diamond Grove (US\$24.5 million), Intermediate Cities Water Supply Rehabilitation Program (US\$12 million), and Strategic Electricity Loss Reduction Program (US\$5 million). 


\begin{tabular}{|c|c|c|c|c|}
\hline \multicolumn{5}{|c|}{$\begin{array}{l}\text { Summary Statement of Active Loans, November } 2010 \\
\text { (In millions of U.S. dollars) }\end{array}$} \\
\hline $\begin{array}{l}\text { Loan or } \\
\text { Credit } \\
\text { No. }\end{array}$ & $\begin{array}{l}\text { Approval } \\
\text { Year }\end{array}$ & Purpose & $\begin{array}{c}\text { Amount } \\
\text { Approved }\end{array}$ & Undisbursed \\
\hline $1103 / \mathrm{SF}$ & 2002 & Unserved Areas Electrification Program & 21.2 & 0.8 \\
\hline $1548 / \mathrm{SF}$ & 2004 & Health Sector Program & 23.0 & 0.8 \\
\hline $1554 / \mathrm{SF}$ & 2004 & Moleson Creek-New Amsterdam Road & 37.3 & 0.7 \\
\hline $1558 / \mathrm{SF}$ & 2004 & Agricultural Support Services & 17.4 & 7.7 \\
\hline $1730 / \mathrm{SF}$ & 2006 & Georgetown Solid Waste Management & 18.1 & 10.5 \\
\hline $\begin{array}{l}1745- \\
6 / \mathrm{SF}\end{array}$ & 2006 & $\begin{array}{l}\text { Modernization of the Justice } \\
\text { Administration System }\end{array}$ & 25.0 & 15.1 \\
\hline $\begin{array}{l}1750- \\
1 / \mathrm{SF}\end{array}$ & 2006 & Support for Competitiveness Program & 26.6 & 15.0 \\
\hline $1752 / \mathrm{SF}$ & 2006 & Citizen Security & 19.8 & 12.7 \\
\hline $1803 / \mathrm{SF}$ & 2006 & $\begin{array}{l}\text { Transport Infrastructure Rehabilitation } \\
\text { Program }\end{array}$ & 24.3 & 15.2 \\
\hline $1929 / \mathrm{SF}$ & 2007 & $\begin{array}{l}\text { Agricultural Export Diversification } \\
\text { Program }\end{array}$ & 20.9 & 15.0 \\
\hline $1938 / \mathrm{SF}$ & 2007 & Power Sector Support Program & 12.0 & 10.0 \\
\hline $2102 / \mathrm{BL}$ & 2008 & Second Low Income Program & 27.9 & 19.8 \\
\hline $2215 / \mathrm{BL}$ & 2009 & $\begin{array}{l}\text { Road Improvement and Rehabilitation } \\
\text { Program }\end{array}$ & 24.8 & 22.4 \\
\hline 2270/BL & 2009 & $\begin{array}{l}\text { Expansion and Integration of Basic } \\
\text { Nutrition Program }\end{array}$ & 5 & 3.7 \\
\hline $2326 / \mathrm{BL}$ & 2010 & $\begin{array}{l}\text { Georgetown Solid Waste Management } \\
\text { Program-Supplementary Financing }\end{array}$ & 2.0 & 1.6 \\
\hline 2428/BL & 2010 & $\begin{array}{l}\text { Georgetown Sanitation Improvement } \\
\text { Program }\end{array}$ & 9.5 & 9.5 \\
\hline 2454/BL & 2010 & $\begin{array}{l}\text { East Bank Demerara Four Lane } \\
\text { Extension }\end{array}$ & 20 & 20 \\
\hline \multicolumn{3}{|c|}{ Total number of credits $=17$} & 334.8 & 180.5 \\
\hline
\end{tabular}




\section{APPENDIX IV. GUYANa: RELATIONS WITH THE CARIBBEAN DEVELOPMENT BANK} (As of October 15, 2010)

The CDB continued to engage Guyana in extensive policy dialogue, capital project financing, and technical assistance that are designed to promote sustainable social and economic development and to reduce poverty. The stock of total loans and grants approved amounted to $\$ 231.2$ million, which is 7.8 percent of total CDB's approvals for member countries on October 15, 2010. Of this amount, 89.3 percent consisted of loans and 10.7 percent of grants. The total outstanding loans were $\$ 130.3$ million and the undisbursed balance was $\$ 14.9$ million on October 15, 2010.

The CDB financed $\$ 73.8$ million for economic and social infrastructure projects, $\$ 68.4$ million for productive sector projects, and $\$ 96.3$ million for multi-sector projects. Under the economic infrastructure sector, the transportation and communication subsector was allocated about $\$ 36.2$ million, or 49 percent of the total economic infrastructure project funding. The manufacturing sector, as well as agriculture, forestry and fishing as a group, also accounted for a large share of project funding. Manufacturing-related-projects were allocated $\$ 45.9$ million or 67.1 percent of total productive sector projects, and agriculturerelated-project activity was allocated 32.7 percent. Currently, there are approximately 30 projects being implemented under the Basic Needs Trust Fund (BNTF) program. Projects include improvements in schools for poor rural communities, roads, drains, bridges, footpaths, water supply, markets and skills training.

The performance of CDB-financed projects under implementation in Guyana remained above the overall average. The table below provides project details of the undisbursed balances as at October 15, 2010.

Summary Statement of Undisbursed Project Balances, October 15, 2010 (In US\$ million)

\begin{tabular}{|c|c|c|c|}
\hline Project Title & $\begin{array}{r}\text { Loan Agreement } \\
\text { Number }\end{array}$ & $\begin{array}{r}\text { Amount } \\
\text { Approved }\end{array}$ & Undisbursed \\
\hline Drainage and Irrigation & 09/SFR-GUY & 5.05 & 0.02 \\
\hline Third Road Project & 2/SFR-OR-GUY & 19.10 & 1.30 \\
\hline Skeldon Sugar Modernization Project & 3/SFR-OR-GUY & 28.36 & 5.59 \\
\hline Reconstruction of Sea Defences & 4/SFR-OR-GUY & 7.35 & 0.42 \\
\hline Community Services Enhancement Project & 5/SFR-OR-GUY & 13.58 & 0.55 \\
\hline Enhanced Technical and Vocational Education and & & & \\
\hline Training & 18/SFR-GUY & 7.50 & 7.08 \\
\hline
\end{tabular}

Source: Caribbean Development Bank. 


\section{APPENDix V. GuYANa: StATistical ISSUES}

(As of November 29, 2010)

Data provided to the Fund is broadly adequate for surveillance purposes, although timeliness, reliability, and coverage of selected data can be improved. Selected data are only available during missions and by telephone/email contacts by the staff. Monetary statistics, exchange rates, interest rates, and financial prudential indicators are available with a lag from the website of the Bank of Guyana (BOG). While specific areas of statistics have received technical assistance, including from the Fund, some limitations remain in the compiling and disseminating selected data in certain sectors. Comprehensive macroeconomic statistics and fiscal data are presented in the Mid Year Report on the annual budget which has been in place since 2007. Guyana has agreed to subscribe to the General Data Dissemination System (GDDS).

\section{Real sector}

Considerable work has been completed to strengthen the national accounts. Building on significant structural changes in the economy since the launch of market-oriented reforms, GDP has been rebased with 2006 prices, reflecting more than sixty percent increase compared to the old GDP, based on 1988 prices. Caribbean Regional Technical Assistance Center (CARTAC) missions visited Georgetown in 2003, 2006, and 2007 and have since provided technical assistance on national accounts, which helped facilitate this exercise for the production side. Further work could entail reassessing the rebased GDP on the expenditure side. To this end, the Bureau of Statistics (BOS) could complete its register of enterprises and secure higher response rates for business surveys. Since January 2010, the BOS has adopted a new household income and expenditure survey (HIES) and launched a new CPI series, reflecting more items in the basket and revised weights. The CPI index reflects movements in prices in the Georgetown area.

\section{Fiscal sector}

A government finance statistics (GFS) mission, which visited Georgetown in May 2005, assisted the authorities in determining the sources of the discrepancy between the fiscal data and monetary and financial data. The mission recommended improvements in the compilation of GFS (such as expanding the coverage of central government operations to include important statutory bodies with their own revenue and accounts) and improving data on the details of domestic financing. The authorities have made progress in implementing these recommendations, including the compilation of quarterly data for the National Insurance Scheme (NIS), and five non-financial public enterprises. Progress on the medium term objective of adopting the methodology of the Government Finance Statistics Manual (GFSM 2001) is proceeding. 


\section{Monetary and financial sectors}

Monetary and financial statistics missions visited Georgetown in 2002, 2003, and 2005. The BOG has made significant progress in improving the quality of monetary statistics, especially as regards the institutional coverage. The monetary statistics currently include the BOG, other depositary corporations (commercial banks, the New Building Society, and trust companies), and other financial corporations (finance companies, life insurance companies, non-life insurance companies, pension funds, and asset management companies). The BOG's monetary statistics provide data for publication in the IFS Supplement, based on standardized report forms. The BOG publishes financial prudential indicators in its quarterly report and on its website on a regular basis.

\section{External sector}

In 2003, a mission from CARTAC noted several weaknesses in the compilation of balance of payments statistics, including that external debt arrears were not recorded in line with the fifth edition of the Balance of Payments Manual, and important financial account transactions were not identified. It recommended that the BOG continue the development of the new reporting form for direct investment, revise the methodology for recording arrears, and seek new data sources for improving the coverage of services. At present, estimates for other services are derived from surveys and an annual survey of major enterprises is used to collect data on inward direct investment. The BOS maintains its own in-house capacity for processing customs data. 


\title{
Guyana: Table of Common Indicators Required for Surveillance
}

\author{
(As of November 29, 2010)
}

\begin{tabular}{|c|c|c|c|c|c|}
\hline & $\begin{array}{c}\text { Date of Latest } \\
\text { Observation } \\
(\mathrm{dd} / \mathrm{mm} / \mathrm{yy})\end{array}$ & $\begin{array}{c}\text { Date } \\
\text { Received } \\
(\mathrm{dd} / \mathrm{mm} / \mathrm{yy}) \\
\end{array}$ & $\begin{array}{l}\text { Frequency of } \\
\text { Data }^{8}\end{array}$ & $\begin{array}{l}\text { Frequency of } \\
\text { Reporting }^{8}\end{array}$ & $\begin{array}{l}\text { Frequency of } \\
\text { Publication }^{8}\end{array}$ \\
\hline Exchange Rates & $31 / 10 / 10$ & $01 / 11 / 10$ & $\mathrm{D}$ & $\mathrm{D}$ & $\mathrm{D}$ \\
\hline $\begin{array}{l}\text { International Reserve Assets and Reserve } \\
\text { Liabilities of the Monetary Authorities }{ }^{1}\end{array}$ & $31 / 10 / 10$ & $01 / 11 / 10$ & $\mathrm{~W}$ & $\mathrm{~W}$ & M \\
\hline Reserve/Base Money & $31 / 10 / 10$ & $01 / 11 / 10$ & $\mathrm{D}$ & W & M \\
\hline Broad Money & $31 / 10 / 10$ & $01 / 11 / 10$ & M & M & M \\
\hline Central Bank Balance Sheet ${ }^{2}$ & $31 / 10 / 10$ & $01 / 11 / 10$ & M & M & M \\
\hline $\begin{array}{l}\text { Consolidated Balance Sheet of the } \\
\text { Banking System }\end{array}$ & $31 / 10 / 10$ & $01 / 11 / 10$ & M & M & M \\
\hline Interest Rates ${ }^{3}$ & $31 / 10 / 10$ & $01 / 11 / 10$ & M & M & M \\
\hline Consumer Price Index & $30 / 09 / 10$ & $01 / 11 / 10$ & M & Q & Q \\
\hline $\begin{array}{l}\text { Revenue, Expenditure, Balance and } \\
\text { Composition of Financing }{ }^{4}-\text { General } \\
\text { Government }^{5}\end{array}$ & $31 / 10 / 10$ & $15 / 11 / 10$ & M & Q & Half yearly \\
\hline $\begin{array}{l}\text { Revenue, Expenditure, Balance and } \\
\text { Composition of Financing }{ }^{4}-\text { Central } \\
\text { Government }\end{array}$ & $31 / 10 / 10$ & $15 / 11 / 10$ & M & Q & Half yearly \\
\hline $\begin{array}{l}\text { Stocks of Central Government and } \\
\text { Central Government-Guaranteed Debt }{ }^{6}\end{array}$ & $30 / 06 / 10$ & $15 / 11 / 10$ & Q & Q & Half yearly \\
\hline External Current Account Balance & $30 / 09 / 10$ & $01 / 11 / 10$ & M & Q & Half yearly \\
\hline $\begin{array}{l}\text { Exports and Imports of Goods and } \\
\text { Services }\end{array}$ & $30 / 09 / 10$ & $01 / 11 / 10$ & M & Q & Half yearly \\
\hline GDP/GNP & 2010 & $01 / 11 / 10$ & A & A & A \\
\hline Gross External Debt & $30 / 09 / 10$ & $01 / 11 / 10$ & A & A & A \\
\hline International Investment Position ${ }^{7}$ & $30 / 06 / 10$ & $01 / 11 / 10$ & N/A & N/A & N/A \\
\hline
\end{tabular}

${ }^{1}$ Includes reserve assets pledged or otherwise encumbered as well as net derivative positions.

${ }^{2}$ Balance sheet information of the Bank of Guyana and the consolidated balance sheet of the other depository corporations on standardized report forms are submitted to the Statistics Department of the IMF.

${ }^{3}$ Both market-based and officially determined, including discount rates, money market rates, rates on treasury bills, notes and bonds.

${ }^{4}$ Foreign, domestic bank, and domestic nonbank financing (partial information).

${ }^{5}$ The general government consists of the central government (budgetary funds, extra budgetary funds, and social security funds) and state and local governments.

${ }^{6}$ Including currency and maturity composition (partial information).

${ }^{7}$ Includes external gross financial asset and liability positions vis-à-vis nonresidents (partial information).

${ }^{8}$ Daily (D), Weekly (W), Monthly (M), Quarterly (Q), Annually (A), Irregular (I), Not Available (NA). 


\title{
INTERNATIONAL MONETARY FUND
}

\author{
GUYANA
}

\section{Joint IMF/World Bank Debt Sustainability Analysis}

Prepared by the Staffs of the World Bank and the International Monetary Fund

Approved by Gilbert Terrier and Dhaneshwar Ghura (IMF) and Carlos Braga and Marcelo Giugale (World Bank)

January 5, 2011

An updated debt sustainability analysis (DSA) yields results in line with those reported in the 2009 Article IV. ${ }^{l}$ Guyana's risk of debt distress remains moderate. Risks of debt distress could arise from both shocks to the growth rate and departure from the agreed fiscal consolidation path. The authorities' continued commitment to fiscal consolidation and structural reforms-including the modernization of the sugar sector-to entrench long-term growth would help reduce these risks over time. Compared to last year's assessment, projected debt ratios are somewhat lower as a stronger growth path is envisioned over the medium term.

\section{BACKGROUND}

1. Debt relief and fiscal consolidation efforts have helped reduce Guyana's external debt burden significantly in recent years. Public sector debt declined from 93.1 percent of GDP in 2006 to $601 \frac{1}{2}$ percent in 2009. In 2006-07, the Fund, the World Bank, and the IDB provided debt relief amounting to US\$611 million under the Multilateral Debt Relief Initiative (MDRI). In November 2006, Japan finalized its bilateral debt cancellation agreement and wrote off its claims as part of the 2004 Paris Club agreement. ${ }^{2}$ Further, the non-financial public sector (NFPS) deficit declined steadily from 8.6 percent of GDP in 2005 to 3.4 percent of GDP in 2009.

2. Since 2007, total gross public debt has remained broadly stable. Total gross public debt stood at 60 percent of GDP in 2007-rising to 61.2 percent of GDP in 2010.

\footnotetext{
${ }^{1}$ See Guyana-Staff Report for the 2009 Article IV Consultation—Debt Sustainability Analysis (IMF Country Report No. 10/292).

${ }^{2}$ Debt relief under the Heavily Indebted Poor Country (HIPC) Initiative was granted by all multilaterals but one, Paris Club bilateral creditors, and four non-Paris Club creditors (China, India, Venezuela, and Cuba). Debt owed to Brazil and North Korea was paid off without relief. The other creditors have yet to provide their share of debt relief.
} 
External debt has increased by new net disbursements from bilateral and multilateral sources, while domestic debt has significantly decreased from 18.3 percent of GDP in 2007, to 13.9 percent in 2010 .

3. Guyana's external debt burden thresholds correspond to the ones associated with a medium policy performance. The CPIA (Country Policy and Institutional Assessment) of Guyana has remained stable at 3.4 during the last three years. A rating between 3.25 and 3.75 corresponds to medium performance. Thus, the relevant thresholds for Guyana are: (i) PV of debt-to-exports ratio of 150 percent; (ii) PV of debt-to-revenue of 250 percent; (iii) PV of debt-to-GDP of 40 percent; and (iv) debt service-to-exports and revenue ratios of 20 and 30 percent, respectively.

\section{MACROECONOMIC FrameWORK}

\section{A. Background}

4. Despite external and domestic shocks in 2010, the Guyanese economy demonstrated resilience and registered a fifth consecutive year of growth. Real GDP is projected to grow by 3.4 percent this year compared with 3.3 percent in 2009 , as output of gold and services expanded. End-year inflation is projected to pick up to 4.4 percent, from 3.7 percent in 2009, reflecting higher food prices. The external current account deficit would widen to 11.3 percent of GDP from 8.7 percent last year, as the value of sugar exports declined while fuel costs were higher. At the same time, official inflows have allowed for a modest increase in gross reserves, to around 5 months of imports.

5. The fiscal outturn for $\mathbf{2 0 1 0}$ represents a temporary deviation from the authorities' fiscal consolidation path. The NFPS deficit (after grants) is expected to rise from 3.4 percent of GDP in 2009 to 4.3 percent of GDP in 2010 (higher than the 3.2 percent of GDP agreed on the 2009 Article IV consultation), as buoyant central government revenues only partly offset the underperformance of public enterprises. Public debt would remain broadly stable at 61 percent of GDP.

\section{B. Baseline Scenario: Projections and Assumptions}

6. The medium-term outlook remains positive (Table 1). The implementation of the Low Carbon Development Strategy (LCDS), and the Amaila Falls Hydropower Plant (AFHP) in particular, would underpin annual growth rates of about 5 percent over the medium term (2011-2015). This path represents a 1 percentage point upward revision from the 2009 Article IV Consultation. The construction of the AFHP would add cumulatively 6 percentage points to growth during 2012-2014, while the public investment projects to be financed with the LCDS inflows (US\$250 million during 2011-2015), will add approximately 0.4 percentage points per year over the medium term. Over the long-term (2016-2030), growth rates will converge to some 3 percent per year. 
7. Although fully financed, the external current account will temporarily widen over the medium term. Capital goods imports associated with the AFHP will cause the current account to widen to some 14/ $\frac{1}{2}$ percent of GDP over the medium term. FDI and official inflows will protect the reserve position at about 5 months of imports. As imports stabilize - partially driven by the fuel import savings associated with the AFHP — and exports recover somewhat in line with improved diversification and private sector investments in gold, oil, and gas sectors, the external current account deficit will slowly improve, reaching $6 \frac{1}{2}$ percent of GDP by 2030 .

\section{Continued fiscal efforts would underpin a steady reduction in debt ratios.} Supported by a stable inflow of grants and improvements in the performance of public enterprises, the proposed fiscal path includes a gradual narrowing of the overall fiscal deficit. In 2011, the baseline scenario envisions a deficit of 3.5 percent of GDP, and a long-term deficit of 2.5 percent of GDP. Gross public debt ratios will decrease moderately to 60.8 percent of GDP over the medium term and will converge to 53 percent in the long term. Domestic debt, while decreasing somewhat over the medium term, would stabilize at some 12 percent of GDP afterwards.

\section{Resilient foreign capital inflows are projected to fully finance the current} account deficit. FDI inflows will peak at some 15 percent of GDP in 2012 and gradually decline to an average of 7 percent of GDP in the long term. Net official borrowing will hover around 5 percent of GDP over the medium term, partly driven by the upfront borrowing projected in the PSIP; however, as the PetroCaribe financing is assumed to be discontinued by 2014 , it will converge to some 2.5 percent of GDP in the long term. Similarly, net official transfers (including budget support grants) are assumed to decrease from its medium-term average of 2.2 percent of GDP to some 1 percent of GDP after $2015 .^{3}$

\section{Assessment of The Baseline Scenario: Gross External DebT ${ }^{4}$}

\section{The analysis of Guyana's gross external debt sustainability suggests that the}

country faces a moderate risk of debt distress. All indicators are well below their threshold values with the exception of PV of gross external debt-to-GDP ratio, which reaches 38.8 percent in 2013, just 1.2 percentage points below the threshold value. The aforementioned upfront borrowing envisioned within the PSIP drives this result. The moderate rating is also supported by a gradual decline in gross external borrowing over the long-term, in line with the envisaged path for fiscal tightening (Table 2, Figure 1).

\footnotetext{
${ }^{3}$ Given the relatively high grant element of PetroCaribe disbursements, as they are discontinued in 2014, the grant element of following years' financing decreases somewhat (assumption consistent with the DSA completed in the 2009 Article IV Consultation).

${ }^{4}$ Gross debt includes the total value of disbursements by Venezuela's PetroCaribe as debt, although the authorities have saved most of these disbursements in an escrow account.
} 
11. The sensitivity analysis shows that Guyana's sustainability indicators are highly vulnerable to some of the standard shocks (Table 3, Figure 1). The PV for the external debt-to-GDP indicator breaches the threshold in all standard tests, and it is particularly vulnerable to a combined shock of real GDP, export value growth, inflation (U.S. dollar GDP deflator), and net non-debt generating flows at one half standard deviation of their historical average (B5). It reaches almost 84 percent in 2012 (i.e., equivalent to 200 percent of the threshold). The PV of external debt-to-revenue breaches its threshold under two of eight tests; while the PV of debt-to-exports breaches its 150 percent limit under one test. For the last two indicators, the most severe shock remains the same combined shock whose results are mostly driven by lower-than-expected FDI flows. In respect of liquidity indicators, debtservice-to-exports and revenue remain well below their corresponding thresholds under all standard tests.

\section{Albeit a low probability event, a "high investment, low growth" scenario} highlights the risks from lower than anticipated returns from the AFHP and other investment projects. A scenario in which the growth benefits of both the AFHP and the LCDS-related investments are absent (2011-2015 growth rate average of 3.4 instead of the baseline 5 percent) includes a minor and temporary breach of the PV of debt-to-GDP ratio threshold (Figure 1). This indicator will reach 40.9 percent by 2014 and return to levels below the 40 percent threshold by 2019 . All the other indicators, however, would remain under their respective thresholds.

\section{Assessment of the Baseline Scenario: Gross Public Debt}

13. The analysis of the dynamics of Guyana's total gross public debt does not alter the overall debt sustainability assessment (Table 4). The projected fiscal consolidation path is consistent with debt sustainability. The PV of public-debt-to-GDP ratio stabilizes at around its 2010 level (i.e., 48 percent) over the projection period. Debt service will hover around 8-13 percent of revenue over the projection period, indicating that the government would have the ability to meet its debt service payments comfortably.

14. Total public debt vulnerabilities to standard shocks highlight the importance of adhering to sound policies (Table 5, Figure 2). The PV of public debt-to-GDP ratio in the test with GDP growth at its historical average minus one standard deviation in 2011-12resulting in growth rates of -1.3-(B1) will steadily increase and would reach 110 percent by 2030. Further, under the same shock, debt service would reach 35 percent of revenue by 2030 , potentially posing debt repayment risks. The high sensitivity to deviations in the growth path is further illustrated by the scenario A3 where growth is assumed to be permanently lower by some 0.7 percentage points over the projection period (averaging 4.2 and 2.5 over the 2011-2015 and 2016-2030 respectively). Under this scenario, the PV of public debt-to-GDP ratio will also steadily increase reaching 87 percent by 2030 while debt service would reach 26 percent of revenue. In addition, if contingent liabilities or other debtcreating flows were to increase by 10 percentage points of GDP in 2011, the PV of the public 
debt-to-GDP ratio will expand to 57 percent over the medium term and moderately decline thereafter (B5).

\section{Conclusion}

15. Guyana remains at a moderate risk of debt distress, albeit with somewhat lower debt ratios than last year's assessment. This assessment is unchanged from the 2009 Article IV Consultation. Debt indicators are below their respective thresholds over the projection period in the baseline scenario. The PV of external debt-to-GDP remains however close to its threshold, which requires close attention to its evolution. The sensitivity analysis of both the external and public-sector debt illustrates the great vulnerability of Guyana's debt dynamics to shocks, in particular to FDI flows and GDP growth. Going forward, Guyana is on the cusp of a structural transformation, led by the government's Low Carbon Development Strategy (LCDS) -which includes enhancing human capital, improving business environment and developing high potential low-carbon sector-; private sector investments in gold, oil, and gas sectors as well as the large PPP associated with the construction of hydroelectric plant.

16. The authorities view the envisioned fiscal consolidation for 2011 and over the medium term as a priority to protect debt sustainability. Further, they considered that their current strategy of using medium term debt sustainability as a fiscal anchor continues to be appropriate. 
Table 1. Guyana: Main Elements of the Macroeconomic Framework

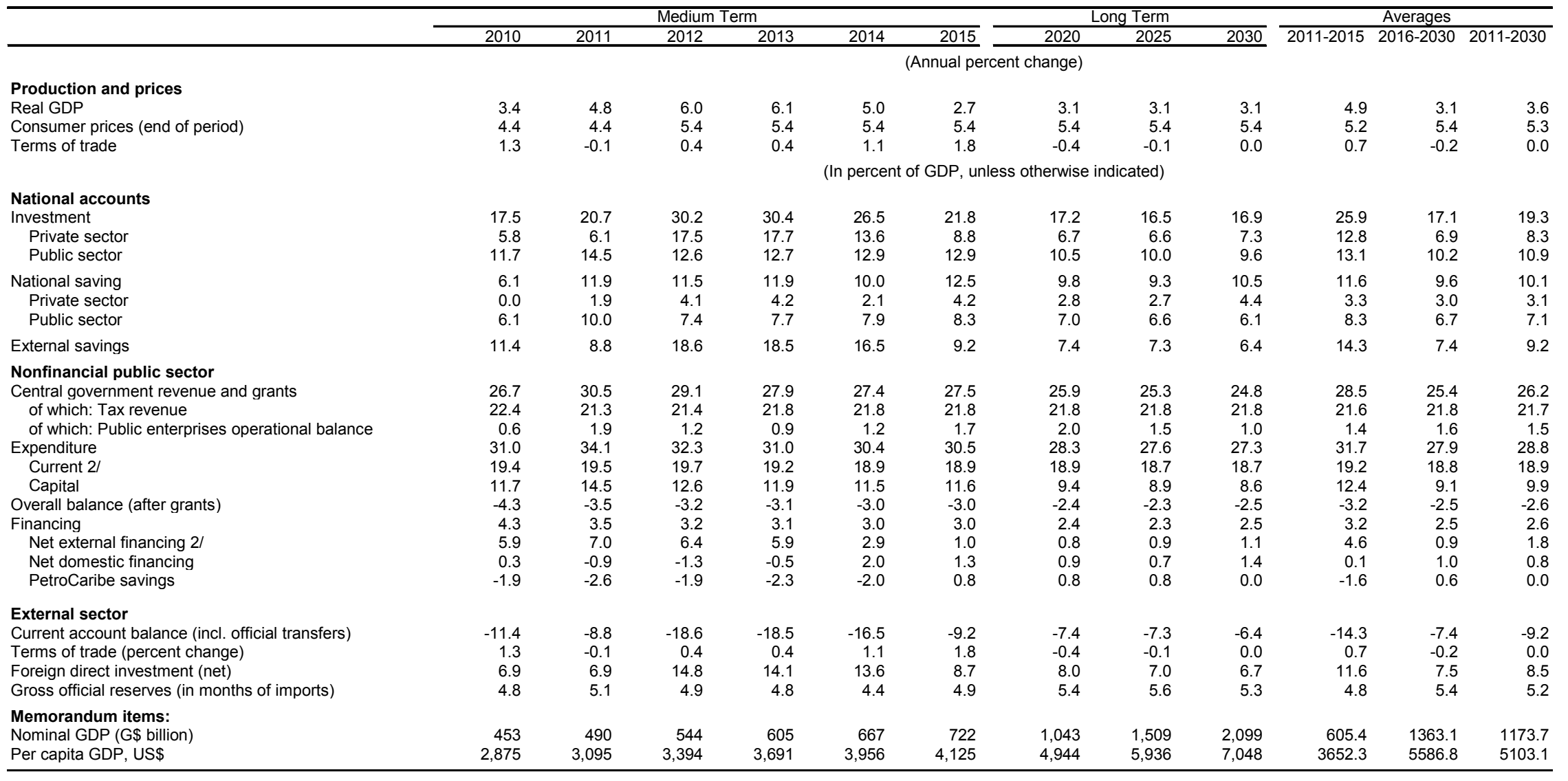

Sources: Guyanese authorities; and Fund staff estimates and projections.

$1 /$ Includes debt service savings under HIPC and MDRI.

2/ Reflects interest and amortizations after debt stock operations.
3/ After delivery of HIPC and MDRI and excluding the unspent portion of PetroCaribe loans in 2007-14. 
Table 2. Guyana: External Debt Sustainability Framework, Baseline Scenario, 2007-2030 1/

(In percent of GDP, unless otherwise indicated)

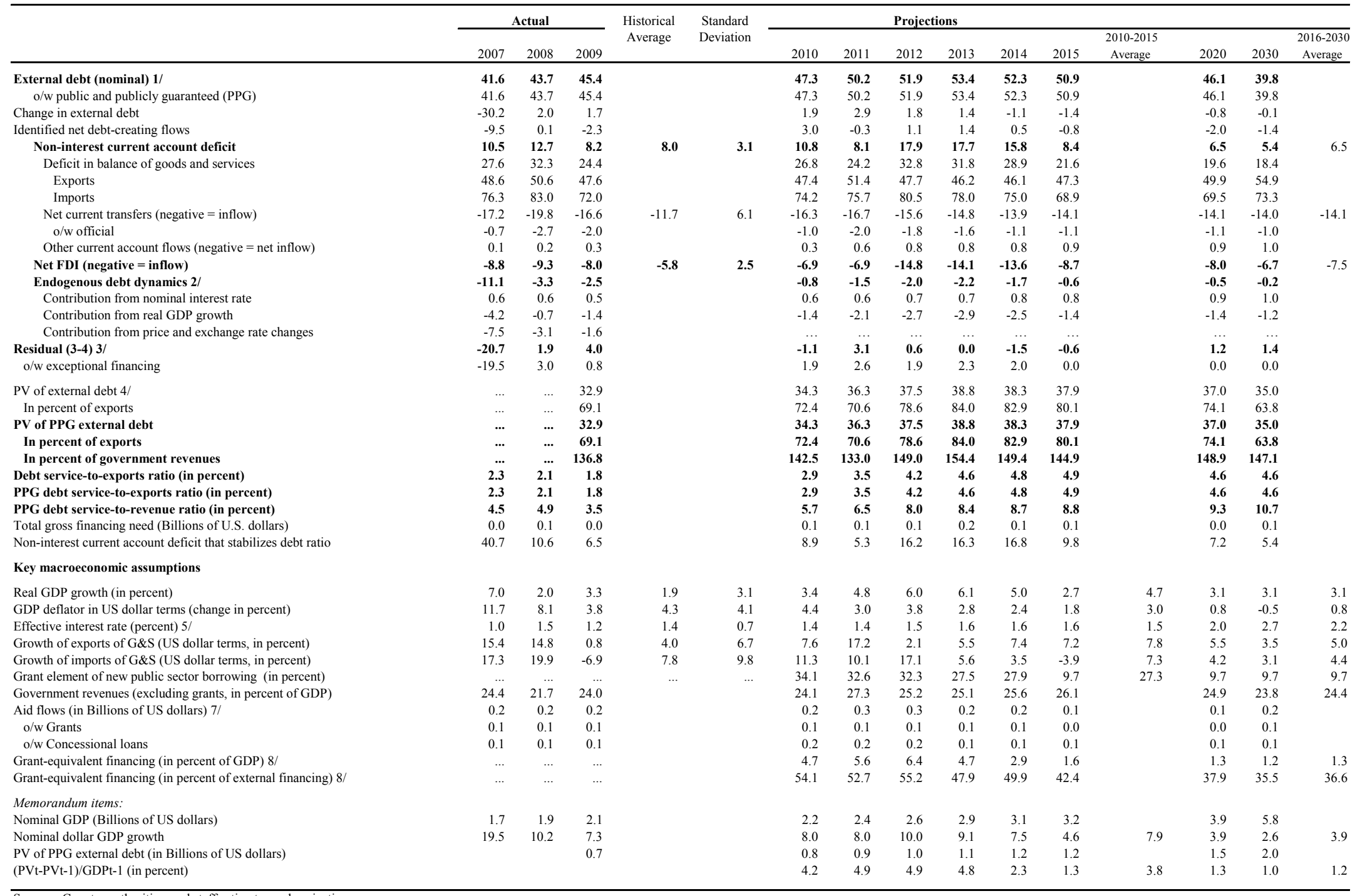

\section{Sources: Country authorities; and staff estimates and projections.}

$1 /$ Includes both public and private sector external debt.

Derived as $[\mathrm{r}-\mathrm{g}-\rho(1+\mathrm{g})](1+\mathrm{g}+\rho+\mathrm{g} \rho)$ times previous period debt ratio, with $\mathrm{r}=$ nominal interest rate; $\mathrm{g}=$ real GDP growth rate, and $\rho=$ growth rate of GDP deflator in U.S. dollar terms.

3 Includes exceptional financing (i.e., changes in arrears and debt relief); changes in gross foreign assets; and valuation adjustments. For projections also includes contribution from price and exchange rate changes.

4/ Assumes that PV of private sector debt is equivalent to its face value.

6/ Historical averages and standard deviations are generally derived over the past 10 years, subject to data availability.

$7 /$ Defined as grants, concessional loans, and debt relief.

8/ Grant-equivalent financing includes grants provided directly to the government and through new borrowing (difference between the face value and the PV of new debt). 
Table 3.Guyana: Sensitivity Analysis for Key Indicators of Public and Publicly Guaranteed External Debt, 2010-2030

(In percent)

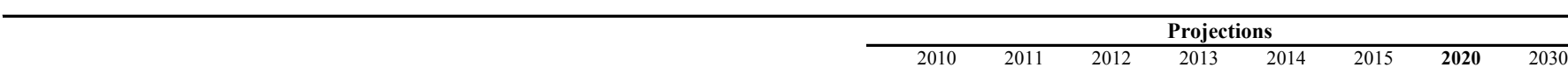

PV of debt-to GDP ratio

Baseline

$\begin{array}{llllllll}34 & 36 & 38 & 39 & 38 & 38 & \mathbf{3 7} & 35 \\ & & & & & & & \\ 34 & 38 & 39 & 40 & 40 & 41 & \mathbf{4 9} & 60 \\ 34 & 38 & 41 & 44 & 44 & 43 & \mathbf{4 6} & 51 \\ & & & & & & & \\ & & & & & & & \\ 34 & 39 & 43 & 44 & 44 & 43 & \mathbf{4 2} & 40 \\ 34 & 44 & 53 & 53 & 52 & 52 & \mathbf{5 0} & 42 \\ 34 & 37 & 40 & 41 & 41 & 40 & \mathbf{3 9} & 37 \\ 34 & 49 & 67 & 67 & 66 & 65 & \mathbf{6 3} & 49 \\ 34 & 55 & 84 & 83 & 81 & 80 & \mathbf{7 8} & 59 \\ 34 & 51 & 53 & 55 & 54 & 53 & \mathbf{5 2} & 49\end{array}$

A1. Key variables at their historical averages in 2010-2030 1/

A1. Key variables at their historical averages in 2010-2030 1/ 20302

B. Bound Tests

B1. Real GDP growth at historical average minus one standard deviation in 2011-2012

B2. Export value growth at historical average minus one standard deviation in 2011-2012 3

B. US dolar GDP deflator at historical average minus one standard deviation in 2011-2012

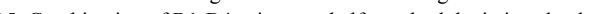

pertine in 20115

\section{PV of debt-to-exports ratio}

Baseline

A. Alternative Scenarios

A1. Key variables at their historical averages in 2010-2030 1/

A2. New public sector loans on less favorable terms in 2010-2030 2

B. Bound Tests

B1. Real GDP growth at historical average minus one standard deviation in 2011-2012

B2. Export value growth at historical average minus one standard deviation in 2011-2012 3

B3. US dollar GDP deflator at historical average minus one standard deviation in 2011-2012

B4. Net non-debt creating flows at historical average minus one standard deviation in 2011-2012 4/

B5. Combination of B1-B4 using one-half standard deviation shocks

B6. One-time 30 percent nominal depreciation relative to the baseline in 2011 5/

\section{PV of debt-to-revenue ratio}

\section{Baseline}

\section{A. Alternative Scenarios}

A1. Key variables at their historical averages in 2010-2030 1/

A2. New public sector loans on less favorable terms in 2010-2030 2

\section{B. Bound Test}

B1. Real GDP growth at historical average minus one standard deviation in 2011-2012

B2. Export value growth at historical average minus one standard deviation in 2011-2012 3/

B4. Net non-debt creating flows at historical average minus one standard deviation in 2011-2012 4/

B5. Combination of B1-B4 using one-half standard deviation shocks

B6. One-time 30 percent nominal depreciation relative to the baseline in 20115 /
72

82

72
72

\section{西}


Table 3.Guyana: Sensitivity Analysis for Key Indicators of Public and Publicly Guaranteed External Debt, 2010-2030 (continued)

(In percent)

\section{Debt service-to-exports ratio}

Baseline

\section{A. Alternative Scenarios}

A1. Key variables at their historical averages in 2010-2030 1/

A2. New public sector loans on less favorable terms in 2010-2030 2

\section{B. Bound Tests}

B1. Real GDP growth at historical average minus one standard deviation in 2011-2012

B2. Export value growth at historical average minus one standard deviation in 2011-2012 3/

B3. US dollar GDP deflator at historical average minus one standard deviation in 2011-2012

B4. Net non-debt creating flows at historical average minus one standard deviation in 2011-2012 4/

B5. Combination of B1-B4 using one-half standard deviation shocks

B6. One-time 30 percent nominal depreciation relative to the baseline in 20115 /

\section{Debt service-to-revenue ratio}

\section{Baselin}

\section{A. Alternative Scenarios}

A1. Key variables at their historical averages in 2010-2030 1/

A2. New public sector loans on less favorable terms in 2010-2030 2

B. Bound Tests

B1. Real GDP growth at historical average minus one standard deviation in 2011-2012

B2. Export value growth at historical average minus one standard deviation in 2011-2012 3/

B3. US dollar GDP deflator at historical average minus one standard deviation in 2011-2012

B4. Net non-debt creating flows at historical average minus one standard deviation in 2011-2012 4/

B5. Combination of B1-B4 using one-half standard deviation shocks

B6. One-time 30 percent nominal depreciation relative to the baseline in $20115 /$

Memorandum item:

Grant element assumed on residual financing (i.e., financing required above baseline) 6 /

$\begin{array}{rrrrrrrr}6 & 7 & 9 & 10 & 10 & 10 & \mathbf{1 1} & 12 \\ 6 & 7 & 9 & 10 & 10 & 10 & \mathbf{1 2} & 14 \\ 6 & 7 & 9 & 9 & 9 & 9 & \mathbf{1 0} & 11 \\ 6 & 7 & 9 & 12 & 12 & 12 & \mathbf{1 4} & 17 \\ 6 & 7 & 11 & 14 & 14 & 14 & \mathbf{1 8} & 21 \\ 6 & 9 & 11 & 12 & 12 & 12 & \mathbf{1 3} & 15 \\ & & & & & & & \\ 15 & 15 & 15 & 15 & 15 & 15 & \mathbf{1 5} & 15\end{array}$

Sources: Country authorities; and staff estimates and projections.

1/ Variables include real GDP growth, growth of GDP deflator (in U.S. dollar terms), non-interest current account in percent of GDP, and non-debt creating flows.

2/ Assumes that the interest rate on new borrowing is by 2 percentage points higher than in the baseline., while grace and maturity periods are the same as in the baseline.

3/ Exports values are assumed to remain permanently at the lower level, but the current account as a share of GDP is assumed to return to its baseline level after the shock (implicitly assuming an offsetting adjustment in import levels).

4/ Includes official and private transfers and FDI.

5/ Depreciation is defined as percentage decline in dollar/local currency rate, such that it never exceeds 100 percent.

6/ Applies to all stress scenarios except for A2 (less favorable financing) in which the terms on all new financing are as specified in footnote 2. 
Table 4. Guyana: Public Sector Debt Sustainability Framework, Baseline Scenario, 2007-2030

(In percent of GDP, unless otherwise indicated)

\begin{tabular}{|c|c|c|c|c|c|c|c|c|c|c|c|c|c|c|c|}
\hline & \multicolumn{3}{|c|}{ Actual } & \multirow[b]{2}{*}{ Average } & \multirow[b]{2}{*}{$\begin{array}{l}\text { Standard } \\
\text { Deviation } \\
\end{array}$} & \multicolumn{4}{|l|}{ Estimate } & \multicolumn{3}{|c|}{ Projections } & \multirow[b]{2}{*}{2020} & \multirow[b]{2}{*}{2030} & \multirow[b]{2}{*}{$\begin{array}{l}2016-30 \\
\text { Average } \\
\end{array}$} \\
\hline & 2007 & 2008 & 2009 & & & 2010 & 2011 & 2012 & 2013 & 2014 & 2015 & $\begin{array}{l}2010-15 \\
\text { Average }\end{array}$ & & & \\
\hline $\begin{array}{l}\text { Public sector debt } 1 / \\
\text { o/w foreign-currency denominated }\end{array}$ & $\begin{array}{l}60.0 \\
41.6\end{array}$ & $\begin{array}{l}61.6 \\
43.7\end{array}$ & $\begin{array}{l}60.5 \\
45.4\end{array}$ & & & $\begin{array}{l}61.2 \\
47.3\end{array}$ & $\begin{array}{l}62.1 \\
50.2\end{array}$ & $\begin{array}{l}61.4 \\
51.9\end{array}$ & $\begin{array}{l}61.4 \\
53.4\end{array}$ & $\begin{array}{l}61.6 \\
52.3\end{array}$ & $\begin{array}{l}60.8 \\
50.9\end{array}$ & & $\begin{array}{l}57.8 \\
46.1\end{array}$ & $\begin{array}{l}53.4 \\
39.8\end{array}$ & \\
\hline Change in public sector debt & -33.1 & 1.6 & -1.1 & & & 0.7 & 0.9 & -0.7 & 0.0 & 0.2 & -0.9 & & -0.7 & 0.8 & \\
\hline Identified debt-creating flows & -30.7 & -1.1 & -0.9 & & & -0.2 & -1.0 & -2.5 & -2.2 & -1.5 & 0.0 & & -0.2 & 1.0 & \\
\hline Primary deficit & 3.4 & 3.4 & 2.1 & 2.4 & 2.6 & 2.8 & 2.1 & 1.8 & 1.8 & 1.7 & 1.6 & 2.0 & 0.8 & 0.8 & 0.9 \\
\hline Revenue and grants & 27.5 & 25.9 & 28.1 & & & 26.7 & 30.5 & 29.1 & 27.9 & 27.4 & 27.5 & & 25.9 & 24.8 & \\
\hline of which: grants & 3.2 & 4.2 & 4.1 & & & 2.6 & 3.2 & 3.9 & 2.8 & 1.8 & 1.3 & & 1.1 & 1.0 & \\
\hline Primary (noninterest) expenditure & 30.9 & 29.3 & 30.2 & & & 29.6 & 32.7 & 30.9 & 29.7 & 29.1 & 29.1 & & 26.8 & 25.5 & \\
\hline Automatic debt dynamics & -13.5 & -4.5 & -3.0 & & & -3.0 & -3.1 & -4.3 & -4.0 & -3.2 & -1.6 & & -1.1 & 0.2 & \\
\hline Contribution from interest rate/growth differential & -8.7 & -2.2 & -1.7 & & & -1.5 & -2.3 & -3.2 & -3.4 & -2.8 & -1.7 & & -1.5 & -0.8 & \\
\hline of which: contribution from average real interest rate & -2.6 & -1.0 & 0.3 & & & 0.5 & 0.5 & 0.3 & 0.2 & 0.1 & 0.0 & & 0.2 & 0.8 & \\
\hline of which: contribution from real GDP growth & -6.1 & -1.2 & -2.0 & & & -2.0 & -2.8 & -3.5 & -3.6 & -2.9 & -1.6 & & -1.8 & -1.6 & \\
\hline Contribution from real exchange rate depreciation & -4.8 & -2.4 & -1.3 & & & -1.6 & -0.8 & -1.1 & -0.6 & -0.4 & 0.0 & & & & \\
\hline Other identified debt-creating flows & -20.5 & 0.0 & 0.0 & & & 0.0 & 0.0 & 0.0 & 0.0 & 0.0 & 0.0 & & 0.0 & 0.0 & \\
\hline Privatization receipts (negative) & 0.0 & 0.0 & 0.0 & & & 0.0 & 0.0 & 0.0 & 0.0 & 0.0 & 0.0 & & 0.0 & 0.0 & \\
\hline Recognition of implicit or contingent liabilities & 0.0 & 0.0 & 0.0 & & & 0.0 & 0.0 & 0.0 & 0.0 & 0.0 & 0.0 & & 0.0 & 0.0 & \\
\hline Debt relief (HIPC and other) & -20.5 & 0.0 & 0.0 & & & 0.0 & 0.0 & 0.0 & 0.0 & 0.0 & 0.0 & & 0.0 & 0.0 & \\
\hline Other (specify, e.g. bank recapitalization) & 0.0 & 0.0 & 0.0 & & & 0.0 & 0.0 & 0.0 & 0.0 & 0.0 & 0.0 & & 0.0 & 0.0 & \\
\hline Residual, including asset changes & -2.5 & 2.7 & -0.1 & & & 0.8 & 1.9 & 1.8 & 2.2 & 1.7 & -0.9 & & -0.5 & -0.2 & \\
\hline \multicolumn{16}{|l|}{ Other Sustainability Indicators } \\
\hline PV of public sector debt & $\ldots$ & $\ldots$ & 48.0 & & & 48.2 & 48.3 & 47.0 & 46.8 & 47.6 & 47.7 & & 48.7 & 48.6 & \\
\hline $\mathrm{o} / \mathrm{w}$ foreign-currency denominated & $\ldots$ & $\ldots$ & 32.9 & & & 34.3 & 36.3 & 37.5 & 38.8 & 38.3 & 37.9 & & 37.0 & 35.0 & \\
\hline $\mathrm{o} / \mathrm{w}$ external & $\ldots$ & $\ldots$ & 32.9 & & & 34.3 & 36.3 & 37.5 & 38.8 & 38.3 & 37.9 & & 37.0 & 35.0 & \\
\hline $\mathrm{PV}$ of contingent liabilities (not included in public sector debt) & $\ldots$ & $\ldots$ & $\ldots$ & & & $\ldots$ & $\ldots$ & $\ldots$ & $\ldots$ & $\ldots$ & & & $\ldots$ & $\ldots$ & \\
\hline Gross financing need $2 /$ & 23.0 & 21.7 & 20.4 & & & 19.1 & 17.5 & 15.3 & 13.0 & 11.7 & 13.1 & & 14.6 & 16.2 & \\
\hline $\mathrm{PV}$ of public sector debt-to-revenue and grants ratio (in percent) & $\ldots$ & $\ldots$ & 170.4 & & & 180.3 & 158.2 & 161.5 & 167.8 & 173.6 & 173.8 & & 187.6 & 196.2 & \\
\hline PV of public sector debt-to-revenue ratio (in percent) & $\ldots$ & $\ldots$ & 199.6 & & & 200.2 & 176.7 & 186.7 & 186.3 & 185.8 & 182.7 & & 195.8 & 204.2 & \\
\hline o/w external 3/ & & & 136.8 & & & 142.5 & 133.0 & 149.0 & 154.4 & 149.4 & 144.9 & & 148.9 & 147.1 & \\
\hline Debt service-to-revenue and grants ratio (in percent) 4/ & 7.2 & 7.1 & 5.8 & & & 8.4 & 8.4 & 9.4 & 9.6 & 9.9 & 10.4 & & 11.4 & 13.1 & \\
\hline Debt service-to-revenue ratio (in percent) $4 /$ & 8.1 & 8.4 & 6.8 & & & 9.3 & 9.4 & 10.8 & 10.7 & 10.6 & 10.9 & & 11.9 & 13.6 & \\
\hline Primary deficit that stabilizes the debt-to-GDP ratio & $\ldots$ & 1.8 & 3.1 & & & 2.2 & 1.2 & 2.5 & 1.8 & 1.5 & 2.5 & & 1.6 & 0.0 & \\
\hline \multicolumn{16}{|l|}{ Key macroeconomic and fiscal assumptions } \\
\hline Real GDP growth (in percent) & 7.0 & 2.0 & 3.3 & 1.9 & 3.1 & 3.4 & 4.8 & 6.0 & 6.1 & 5.0 & 2.7 & 4.7 & 3.1 & 3.1 & 3.1 \\
\hline Average nominal interest rate on forex debt (in percent) & 1.0 & 1.5 & 1.2 & 1.4 & 0.7 & 1.4 & 1.4 & 1.5 & 1.6 & 1.6 & 1.6 & 1.5 & 2.0 & 2.7 & 2.2 \\
\hline Average real interest rate on domestic debt (in percent) & -6.8 & -4.1 & 0.9 & 4.3 & 9.6 & 1.9 & 2.7 & 1.6 & 1.8 & 1.7 & 1.1 & 1.8 & 1.6 & 4.2 & 1.8 \\
\hline Real exchange rate depreciation (in percent, + indicates depreciation) & -7.3 & -5.8 & -3.1 & -1.9 & 3.6 & -3.5 & $\ldots$ & $\ldots$ & $\ldots$ & $\ldots$ & $\ldots$ & $\ldots$ & $\ldots$ & $\ldots$ & $\ldots$ \\
\hline Inflation rate (GDP deflator, in percent) & 12.7 & 9.0 & 3.7 & 5.7 & 3.7 & 4.3 & 3.2 & 4.8 & 4.8 & 5.0 & 5.4 & 4.6 & 4.4 & 1.5 & 4.2 \\
\hline Growth of real primary spending (deflated by GDP deflator, in percent) & 0.0 & 0.0 & 0.1 & 0.1 & 0.1 & 0.0 & 0.2 & 0.0 & 0.0 & 0.0 & 0.0 & 0.0 & 0.0 & 0.0 & 0.0 \\
\hline Grant element of new external borrowing (in percent) & $\ldots$ & $\ldots$ & $\ldots$ & $\ldots$ & $\ldots$ & 34.1 & 32.6 & 32.3 & 27.5 & 27.9 & 9.7 & 27.3 & 9.7 & 9.7 & ... \\
\hline
\end{tabular}

Sources: Country authorities; and staff estimates and projection.

2/ Gross financing need is defined as the primary deficit plus debt service plus the stock of short-term debt at the end of the last period.

$3 /$ Revenues excluding grants.

4/ Debt service is defined as the sum of interest and amortization of medium and long-term debt.

$5 /$ Historical averages and standard deviations are generally derived over the past 10 years, subject to data availability. 
Table 5.Guyana: Sensitivity Analysis for Key Indicators of Public Debt 2010-2030

\begin{tabular}{|c|c|c|c|c|c|c|c|c|}
\hline & \multicolumn{8}{|c|}{ Projections } \\
\hline & 2010 & 2011 & 2012 & 2013 & 2014 & 2015 & 2020 & 2030 \\
\hline \multicolumn{9}{|c|}{ PV of Debt-to-GDP Ratio } \\
\hline Baseline & 48 & 48 & 47 & 47 & 48 & 48 & 49 & 49 \\
\hline \multicolumn{9}{|l|}{ A. Alternative scenarios } \\
\hline A1. Real GDP growth and primary balance are at historical averages & 48 & 50 & 51 & 53 & 56 & 57 & 66 & 87 \\
\hline A2. Primary balance is unchanged from 2010 & 48 & 49 & 48 & 49 & 51 & 52 & 60 & 78 \\
\hline A3. Permanently lower GDP growth $1 /$ & 48 & 49 & 48 & 49 & 50 & 52 & 60 & 87 \\
\hline \multicolumn{9}{|l|}{ B. Bound tests } \\
\hline B1. Real GDP growth is at historical average minus one standard deviations in 2011-2012 & 48 & 53 & 58 & 61 & 65 & 68 & 83 & 111 \\
\hline B2. Primary balance is at historical average minus one standard deviations in 2011-2012 & 48 & 51 & 52 & 52 & 52 & 52 & 53 & 53 \\
\hline B3. Combination of B1-B2 using one half standard deviation shocks & 48 & 52 & 55 & 57 & 60 & 62 & 74 & 94 \\
\hline B4. One-time 30 percent real depreciation in 2011 & 48 & 62 & 59 & 57 & 57 & 58 & 61 & 66 \\
\hline B5. 10 percent of GDP increase in other debt-creating flows in 2011 & 48 & 57 & 56 & 55 & 55 & 55 & 56 & 55 \\
\hline \multicolumn{9}{|c|}{ PV of Debt-to-Revenue Ratio 2/ } \\
\hline Baseline & 180 & 158 & 161 & 168 & 174 & 174 & 188 & 196 \\
\hline \multicolumn{9}{|l|}{ A. Alternative scenarios } \\
\hline A1. Real GDP growth and primary balance are at historical averages & 180 & 163 & 173 & 188 & 202 & 206 & 253 & 347 \\
\hline A2. Primary balance is unchanged from 2010 & 180 & 160 & 167 & 176 & 186 & 190 & 233 & 313 \\
\hline A3. Permanently lower GDP growth $1 /$ & 180 & 160 & 165 & 174 & 183 & 187 & 231 & 348 \\
\hline \multicolumn{9}{|l|}{ B. Bound tests } \\
\hline B1. Real GDP growth is at historical average minus one standard deviations in 2011-2012 & 180 & 172 & 196 & 215 & 233 & 245 & 320 & 444 \\
\hline B2. Primary balance is at historical average minus one standard deviations in 2011-2012 & 180 & 167 & 180 & 186 & 191 & 191 & 205 & 213 \\
\hline B3. Combination of B1-B2 using one half standard deviation shocks & 180 & 169 & 185 & 201 & 216 & 225 & 284 & 380 \\
\hline B4. One-time 30 percent real depreciation in 2011 & 180 & 202 & 201 & 205 & 210 & 211 & 236 & 266 \\
\hline B5. 10 percent of GDP increase in other debt-creating flows in 2011 & 180 & 187 & 191 & 196 & 202 & 201 & 216 & 223 \\
\hline
\end{tabular}

Debt Service-to-Revenue Ratio 2/

Baseline

\section{A. Alternative scenarios}

A1. Real GDP growth and primary balance are at historical averages

A2. Primary balance is unchanged from 2010

A3. Permanently lower GDP growth 1/

$\begin{array}{rrrrrrrr}8 & 9 & 10 & 11 & 12 & 13 & 16 & 25 \\ 8 & 8 & 9 & 11 & 11 & 12 & 15 & 24 \\ 8 & 8 & 9 & 10 & 11 & 12 & 15 & 26\end{array}$

\section{B. Bound tests}

B1. Real GDP growth is at historical average minus one standard deviations in 2011-2012

B2. Primary balance is at historical average minus one standard deviations in 2011-2012

B3. Combination of B1-B2 using one half standard deviation shocks

B4. One-time 30 percent real depreciation in 2011

B5. 10 percent of GDP increase in other debt-creating flows in 2011

$\begin{array}{rrrrrrrr}8 & 9 & 11 & 13 & 16 & 17 & 22 & 35 \\ 8 & 8 & 10 & 13 & 14 & 12 & 12 & 15 \\ 8 & 9 & 10 & 12 & 13 & 16 & 19 & 29 \\ 8 & 10 & 12 & 13 & 14 & 15 & 18 & 23 \\ 8 & 8 & 11 & 20 & 11 & 14 & 13 & 16\end{array}$

Sources: Country authorities; and staff estimates and projections.

1/ Assumes that real GDP growth is at baseline minus one standard deviation divided by the square root of the length of the projection period.

2/ Revenues are defined inclusive of grants. 
Figure 1. Guyana: Indicators of Public and Publicly Guaranteed External Debt Under Alternative Scenarios, 2010-30 1/

a. Debt Accumulation

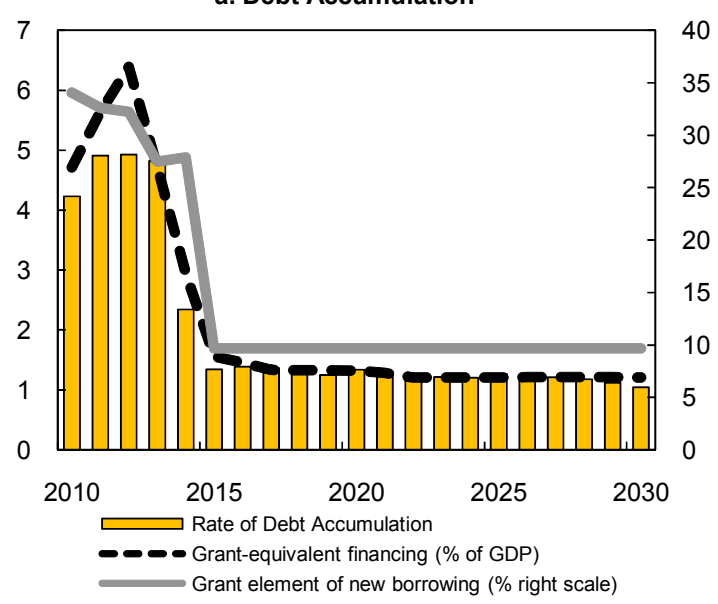

c. PV of debt-to-exports ratio

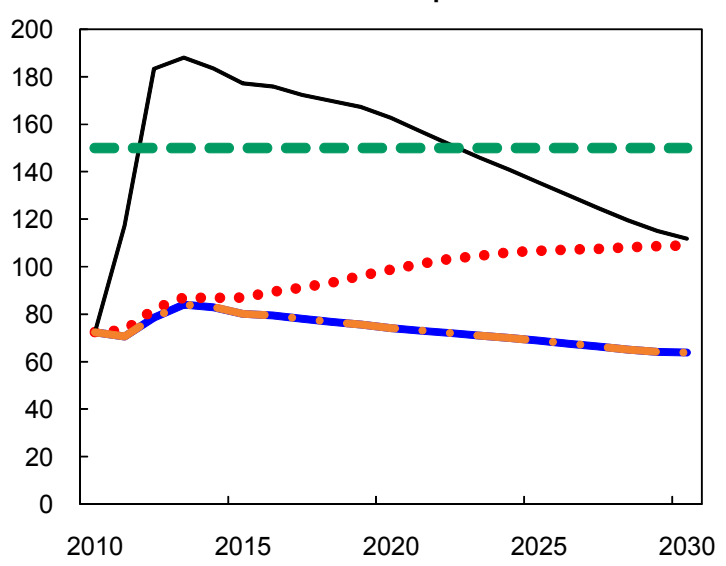

e. Debt service-to-exports ratio

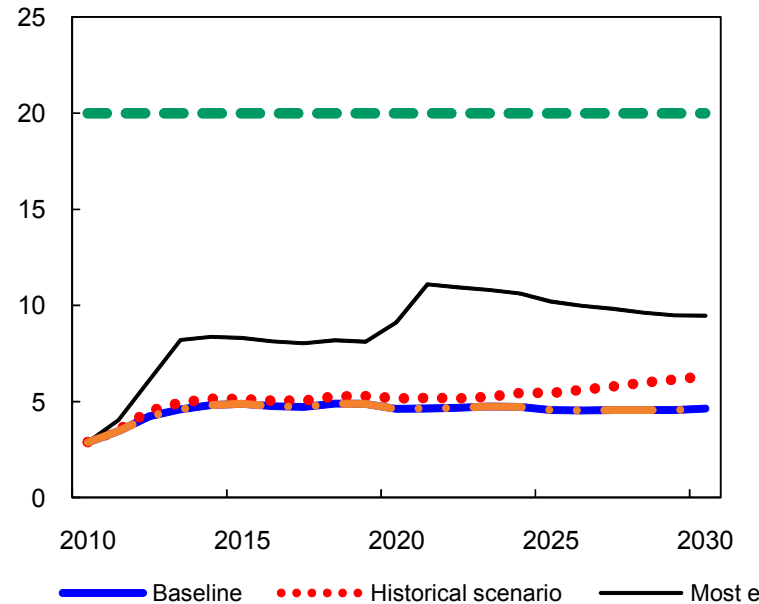

b. PV of debt-to GDP ratio

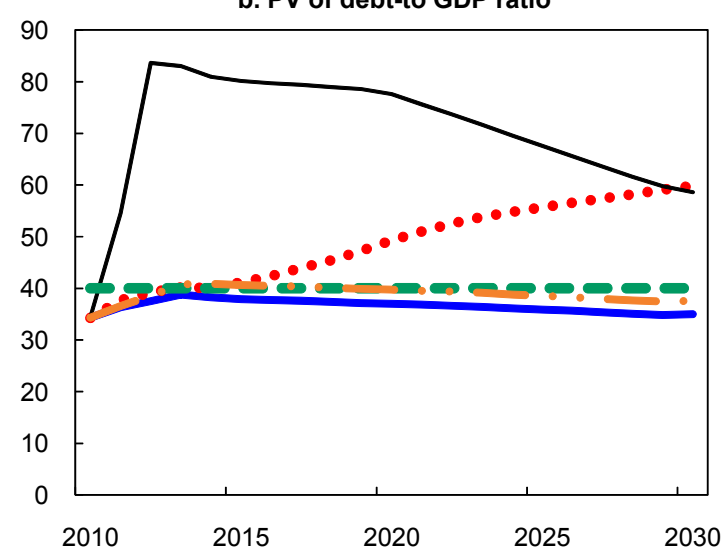

d. PV of debt-to-revenue ratio

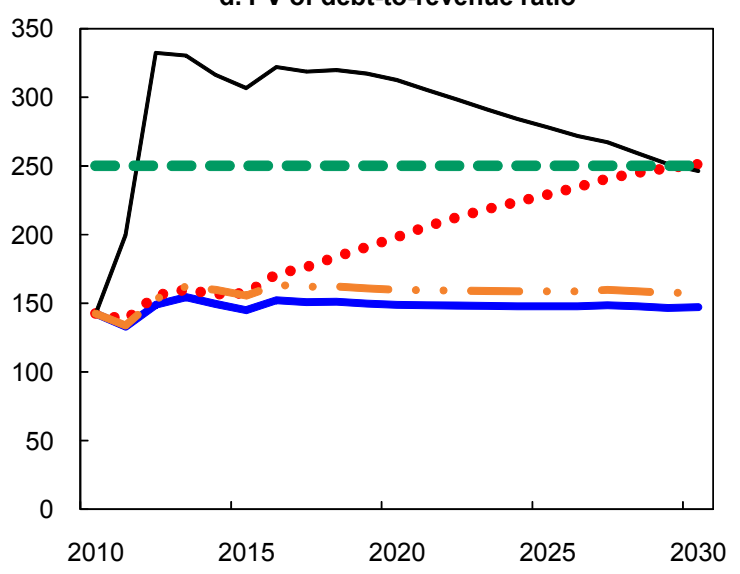

f. Debt service-to-revenue ratio

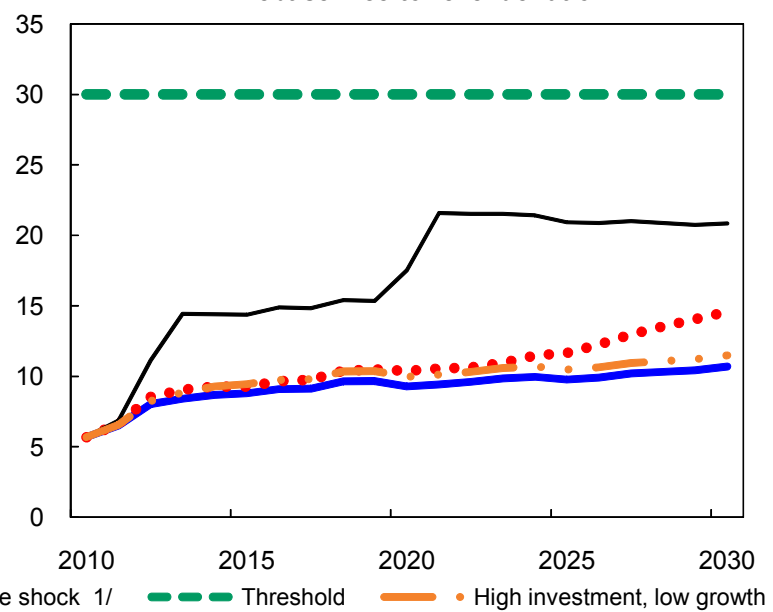

Sources: Country authorities; and staff estimates and projections.

$1 /$ The most extreme stress test is the test that yields the highest ratio in 2020. In figure b. it corresponds to a Combination shock; in c. to a Combination shock; in d. to a Combination shock; in e. to a Combination shock and in figure f. to a Combination shock. 
Figure 2. Guyana: Indicators of Public Debt Under

Alternative Scenarios, 2010-301/
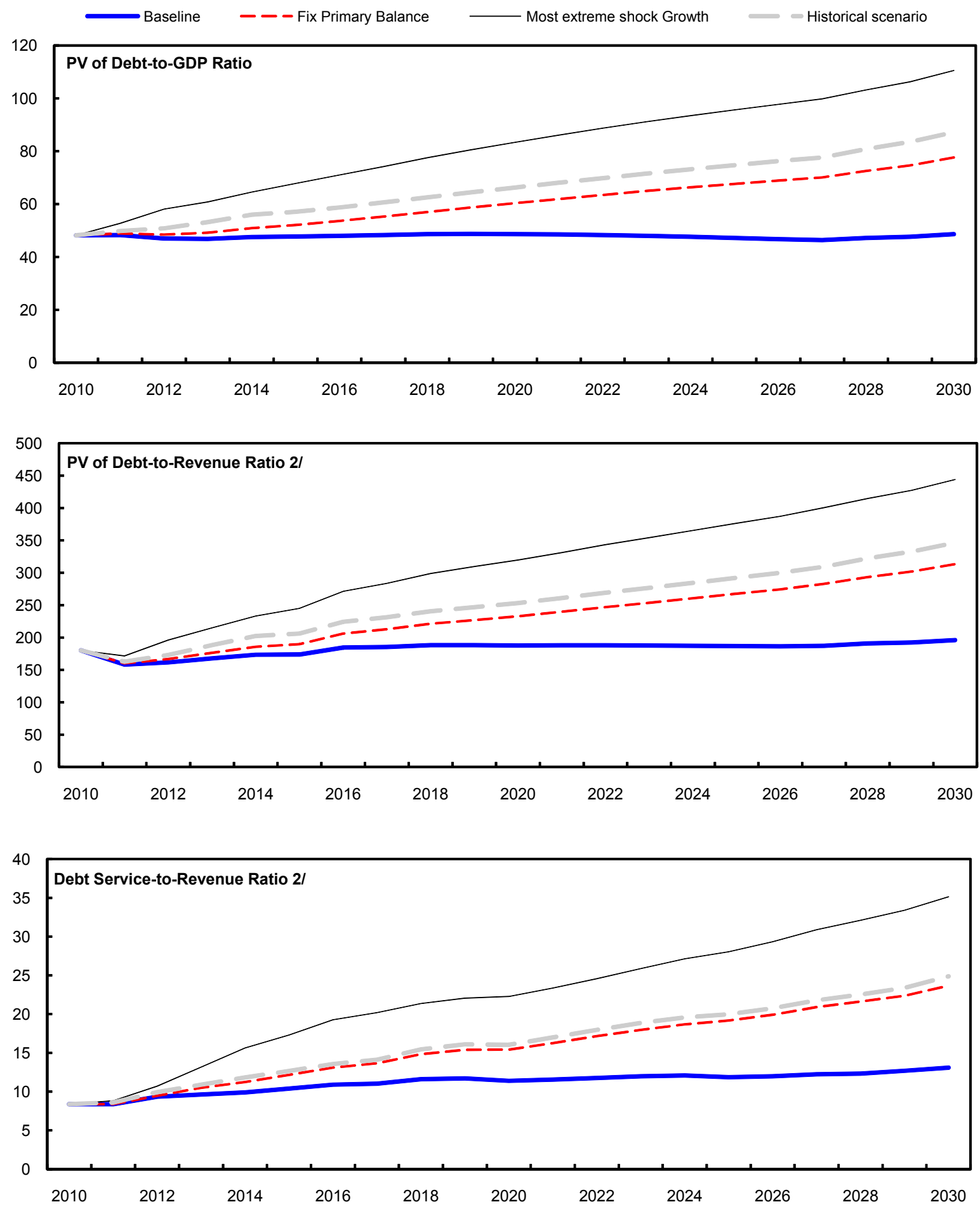

Sources: Country authorities; and staff estimates and projections.

$1 /$ The most extreme stress test is the test that yields the highest ratio in 2020.

2/ Revenues are defined inclusive of grants. 


\section{INTERNATIONAL MONETARY FUND}

EXTERNAL Public Information Notice RELATIONS DEPARTMENT

Public Information Notice (PIN) No. 11/29 FOR IMMEDIATE RELEASE March 4, 2011
International Monetary Fund $70019^{\text {th }}$ Street, NW

Washington, D. C. 20431 USA

\section{IMF Executive Board Concludes 2010 Article IV Consultation with Guyana}

On February 16, 2011, the Executive Board of the International Monetary Fund (IMF) concluded the Article IV consultation with Guyana. ${ }^{32}$

\section{Background}

Despite external and domestic shocks, the Guyanese economy demonstrated resilience and registered a fifth consecutive year of robust growth in 2010. Real Gross Domestic Product (GDP) expanded by around 3.4 percent, slightly more than in 2009, supported by expansion in the gold and services sectors, which helped offset lower output in the sugar sector. End-year inflation rose to 4.4 percent, from 3.7 percent in 2009 , reflecting higher food prices. Although the external current account deficit is estimated to have widened to 11.4 percent of GDP, a steady inflow of public external financing and foreign direct investment were sufficient to finance the deficit and strengthen foreign reserves to the equivalent of 5 months of imports.

In 2010, the overall fiscal balance is estimated to have weakened by close to 1 percentage point of GDP, to 4.3 percent of GDP, due to weak performance in public enterprises, not fully offset by a decline in investment and despite strong central government revenues. Public debt was broadly unchanged, at 61 percent of GDP. Meanwhile, bank prudential indicators have remained stable, with banks generally liquid and well capitalized. In September 2010, the authorities started making payouts to Colonial Life Insurance Company (CLICO) policy holders, in line with their plans to minimize fiscal costs.

\footnotetext{
${ }^{32}$ Under Article IV of the IMF's Articles of Agreement, the IMF holds bilateral discussions with members, usually every year. A staff team visits the country, collects economic and financial information, and discusses with officials the country's economic developments and policies. On return to headquarters, the staff prepares a report, which forms the basis for discussion by the Executive Board. At the conclusion of the discussion, the Managing Director, as Chairman of the Board, summarizes the views of Executive Directors, and this summary is transmitted to the country's authorities. An explanation of any qualifiers used in summings up can be found here: http://www.imf.org/external/np/sec/misc/qualifiers.htm.
} 
During 2010, structural reforms focused on improving the policy framework and supporting long term growth. In the area of fiscal policy, efforts to improve the Guyana Revenue Authority (GRA) continued. Its new functional organization was consolidated, improving further the integrated tax information system (TRIPS), the profiling of taxpayers, and on-site inspections at the country's ports of entry. In support of long-term growth, the authorities continued their modernization plans in the sugar industry with the reorientation of cane fields to accommodate mechanization. In the financial sector, the authorities passed the Credit Bureau Act, and widened the regulatory perimeter by bringing the New Building Society under the jurisdiction of the Bank of Guyana. On the infrastructure front, major refurbishment and upgrading of the electricity transmission and distribution network, along with the access road to the Amaila Falls hydro power plant project site, have commenced. In the area of statistics, the authorities have signed on to the IMF's General Data Dissemination System (GDDS).

Guyana's outlook remains positive for 2011, an election year, and through the medium term. Road projects, construction of a large hydropower plant at Amaila Falls (AFHP), and implementation of the Low Carbon Development Strategy (LCDS) should sustain growth levels above the long-run trend of 3 percent, at around 5 percent over the medium term before tapering off in 2015 as one-off projects are completed. Downside risks include those linked to fiscal pressures arising from lagging productivity in Guyana Sugar Corporation (GUYSUCO), the need to strengthen the finances of the National Insurance Scheme (NIS), and a possible fall off in aid commitments.

\section{Executive Board Assessment}

Directors commended the authorities for macroeconomic policies that have supported resilience in the face of external and domestic shocks. They noted that the development of forestry-based environmental services, private sector plans for the exploitation of Guyana's natural resources, and large infrastructure investments are supporting Guyana's medium-term growth prospects.

Directors welcomed the authorities' continued commitment to fiscal prudence and recommended contingency measures to mitigate risks from volatile grant disbursements. In this regard, a few Directors called on the donor community to fulfill their development assistance commitments. Directors noted that further strengthening the fiscal position calls for far-reaching reforms in the National Insurance System and key public enterprises. Directors also encouraged the authorities to monitor carefully the fiscal risks associated with the construction of a large hydro power plant, advising the adoption of international best practices for public-private partnerships.

Directors considered that monetary management has been key to macroeconomic stability. They noted that there may be scope for early tightening, if increases in commodity prices were to threaten the authorities' inflation objective. Directors agreed that Guyana's exchange rate regime has served the country well. Going forward, some Directors supported a gradual approach toward greater exchange rate flexibility, while others considered the current policy to be appropriate.

Noting that financial sector indicators had improved, Directors stressed the need for continued close prudential oversight. They welcomed the laws establishing the licensing and supervisory framework for credit bureau operations and bringing the mortgage bank under the supervision of the central bank. 
Directors endorsed the authorities' Low Carbon Development Strategy, which seeks to boost competitiveness and private investment. Its successful implementation, with international support, will lift Guyana's long-term growth prospects and reduce poverty. Considering the authorities' intention to finalize soon their poverty reduction strategy, Directors encouraged a continued dialogue with all stakeholders to maintain consensus on the development agenda.

Directors noted the improvements in data quality achieved in 2010 and welcomed the authorities' decision to subscribe to the Fund's General Data Dissemination System.

Public Information Notices (PINs) form part of the IMF's efforts to promote transparency of the IMF's views and analysis of economic developments and policies. With the consent of the country (or countries) concerned, PINs are issued after Executive Board discussions of Article IV consultations with member countries, of its surveillance of developments at the regional level, of post-program monitoring, and of ex post assessments of member countries with longer-term program engagements. PINs are also issued after Executive Board discussions of general policy matters, unless otherwise decided by the Executive Board in a particular case. 
Guyana: Selected Economic Indicators

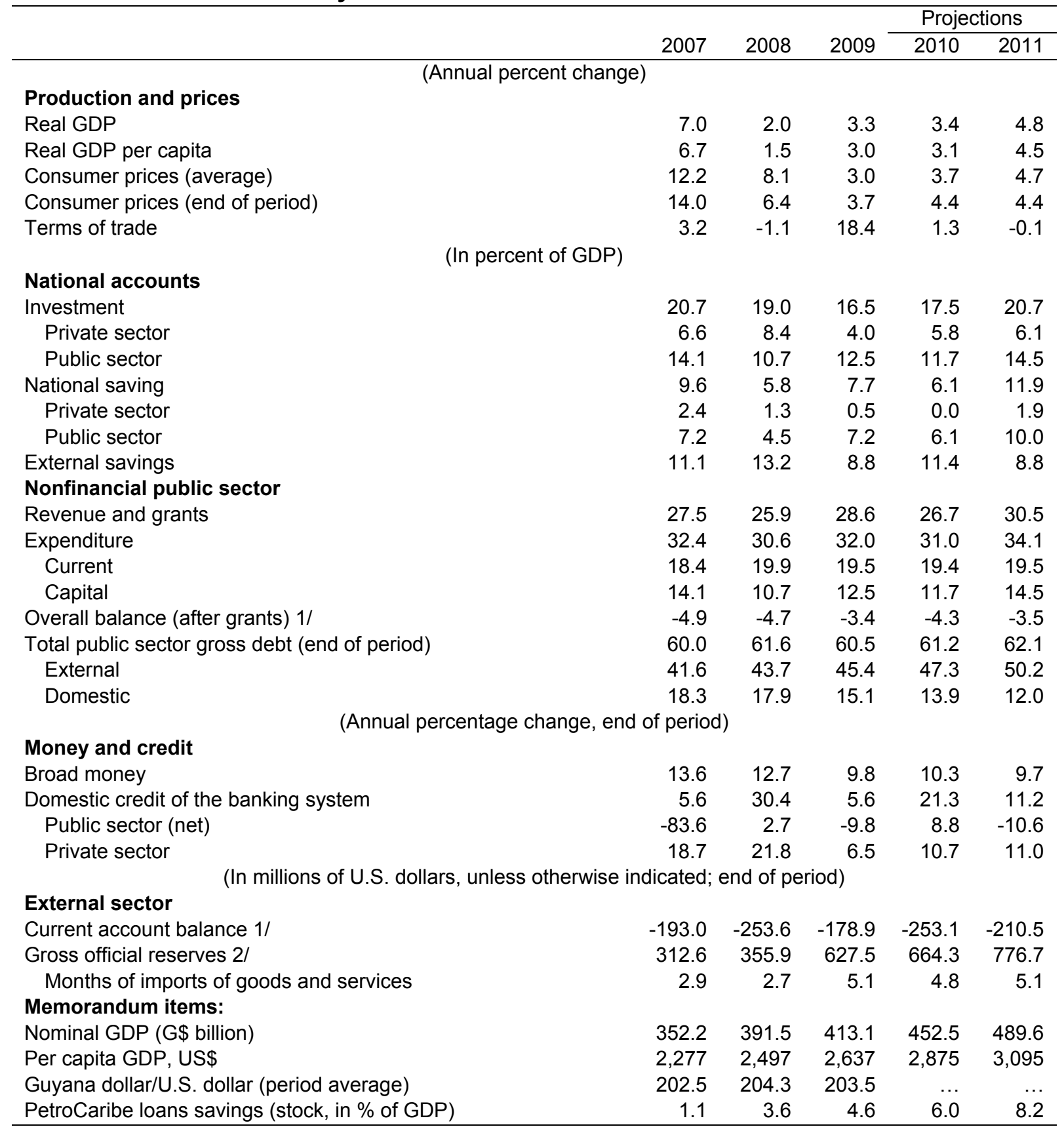

Sources: Guyanese authorities; UNDP Human Devt. Report 2009; and IMF staff estimates and projections. $1 /$ Including official transfers.

2/ Includes SDR allocation. 


\section{Statement by Paulo Nogueira Batista, Executive Director for Guyana, Asgar Ally, Senior Advisor to the Executive Director and Nicole Leslie-Ann Des Vignes, Senior Advisor to the Executive Director}

1. Our Guyanese authorities thank staff for the discussions and policy advice during the 2010 Article IV mission.

2. Guyana's economy remained resilient in 2010 despite the difficult global and regional economic circumstances. Prudent management of the economy continued to yield dividends and improvements in the lives of the Guyanese people. Yet, the authorities are not complacent, they are aware that there are still vulnerabilities to be overcome. The Low Carbon Development Strategy (LCDS) is geared towards alleviating some of the remaining challenges.

\section{Recent Economic Developments}

3. The economy registered a fifth consecutive year of robust growth in 2010 as it expanded by 3.6 percent. The non-sugar sector grew by 4.3 percent reflecting a more diversified and resilient economy. Production of nontraditional crops increased significantly in response to the 'Grow More Food Campaign.' Thanks to favorable world market prices and investments in the gold sector, gold production and exports reached their highest levels, surpassing the achievements of 2009. Rice production also realized a new record. In addition, strong growth occurred in the construction, financial and insurance services and the distribution sectors.

4. In spite of the higher exports of rice, gold and bauxite and increased remittances, the current account of the balance of payments widened due to lower sugar output and prices and higher fuel import costs. Notwithstanding this, the deficit was fully financed and net international reserves rose, peaking at US\$780 million, equivalent to five months of imports. 
5. The authorities continued to implement a prudent fiscal policy geared at ensuring debt sustainability. In light of the ongoing fiscal reforms and significant improvement to the operations of the Guyana Revenue Authorities, central government revenues improved as tax collections increased across most categories in 2010. Together with a reduction in expenditure, this resulted in a central government deficit of 3 percent of GDP, below the budgeted target of 3.3 percent. Nevertheless, the nonfinancial public sector's overall fiscal deficit widened to 4.3 percent of GDP due to the shortfall in sugar production, the increased investment expenditure of the electricity generating company and lower grant disbursements.

6. The public sector gross debt averaged 60.8 percent of GDP over the last four years, increasing slightly in 2010 but remaining within the debt sustainability thresholds. More importantly, the debt service to revenue ratio remained relatively low. Our authorities are committed to safeguarding debt sustainability and are actively seeking development support and assistance from partners. Moreover, they are steadfastly pursuing loans on the most favorable concessional terms and also continue to negotiate with bilateral non-Paris Club creditors for debt reduction.

7. Effective use has been made of the assistance provided by the multilateral institutions and donor countries and Guyana is grateful for the support it has received in the past. However, our authorities wish to indicate that some providers of development assistance have become unreliable resulting in unpredictable inflows in recent times. We encourage greater commitment from development partners. Guyana's government looks forward to the continuation of international assistance to complement its efforts in accelerating structural transformation and sustained economic expansion.

8. Monetary policy focused on maintaining price and exchange rate stability while encouraging the expansion of credit to the private sector. The monetary policy stance was moderately expansionary to meet the needs of the private sector. Interest rates trended downwards during 2010, with the 91 day treasury bill rate 
declining by 40 basis points, thereby reducing the cost of borrowing to businesses. As private sector credit expansion gains momentum it is expected that there will be a reduction in the high levels of liquidity in the financial system. Inflation was contained to modest levels in 2010 at 4.5 percent. The exchange rate which is determined by market forces remained stable and consistent with macroeconomic fundamentals during the year. Our authorities note the suggestion by staff for more exchange rate flexibility, but reiterate the firm view that the current exchange rate arrangement and the exchange rate stability that has been achieved have served the country well.

9. On the financial front, the system remained liquid with improvements to capital, profitability, provisioning and non-performing loans ratios. The non-performing loan ratio continued its declining trend to reach 6 percent in 2010 compared with 17.8 percent in 2004 . The authorities continued to strengthen the regulatory and supervisory framework. Quarterly stress testing has been introduced and on site investigations were also conducted. A number of legislative measures aimed at strengthening the financial sector and achieving greater compliance with recommended international best practices were enacted in 2010.These are adequately highlighted in the staff report.

10. Moreover, the authorities have made significant progress in resolution of the CLICO debacle in Guyana. The authorities in Guyana are the first in the region to commence payouts to CLICO policy holders in their jurisdiction. The government provided an injection of GUY $\$ 3.6$ billion to fund the immediate payouts subject to a maximum of $\$ 30$ million per policy holder. To date 4,567 policy holders have been given cheques totaling $\$ 3.1$ billion. The resolution process is ongoing as actions are being taken to secure the remainder of the company's assets.

\section{Outlook}

11. The medium-term outlook for Guyana is positive given the authorities development agenda premised on the LCDS, the Amalia Falls Hydroelectric 
Power plant (AFHP) Project, oil and gas exploration and increased production and productivity of Guyana Sugar Corporation (Guysuco). Building on the favorable performance of the economy over the last five years the authorities are preserving and improving the gains of prudent macroeconomic management. According to staff, real GDP growth is expected to reach 4.8 percent in 2011 and to average 5.7 percent over 2012 to 2014.

12. Our authorities remain committed to fiscal prudence, even in this election year. Although, the authorities' 2011 budget is focused on fiscal consolidation it also entails measures geared at promoting growth and poverty reduction. Specific measures were included to benefit the vulnerable members of society and the rapidly growing private sector. Public assistance was increased by 12 percent and old age pensions by 14 percent. The Personal Income Tax threshold was increased by 14 percent to allow workers a greater take home pay. The Corporate Tax on Profits was reduced by 5 percentage points to allow the private sector to retain more of their profits for investment activities.

13. The National Insurance Scheme (NIS) is a defined benefit pension arrangement which covers about a third of the working population. As noted in the staff report, a recent actuarial review has recommended parametric reforms to improve its viability. Our authorities are currently examining options for corrective action to improve the viability of the NIS.

14. Guyana began receiving payments for forest climate services in 2010 , and these inflows will be directed towards the transformation of the economy along a low carbon development path. The first set of projects to commence under the LCDS in 2011 includes the provision of equity financing for the Amalia Falls Hydropower Project, support to the demarcation of Amerindian lands, rural electrification, financing for Small and Microenterprise Development, and support to the Amerindian Development Fund to finance indigenous community projects. The authorities will continue to advance their model of Avoided Deforestation 
and to build partnerships regionally and internationally as they seek to expand the financial support for the LCDS.

15. The authorities continue to make progress on the Amalia Hydropower Falls Project (AFHP), which is being developed as a public-private partnership using a twenty year Build Own Operate Transfer Model. The contract for the construction of the access road was awarded last year. The AFHP is sized at $154 \mathrm{Mw}$ with the financing of this project at US\$650 million coming from equity contributed by Sithe Global, equity from Government under the LCDS and debt financing. The project construction will start in late 2011, while the commercial operations will commence by 2015. The AFHP is a major transformative project for Guyana since it will allow for a quantum shift from being a country heavily dependent on fossil fuels for electric power to one meeting its entire national requirements through clean renewable sources by 2015.

16. In parallel, the authorities are engaged in promoting the exploration of oil and gas resources. Private estimates indicate potential oil reserves at 15.2 billion barrels and output of 50 million barrels annually. Several companies are already involved in drilling operations.

17. The authorities are taking steps to improve the operations at Guysuco allowing it to recover its production and productivity levels and restore its financial performance. Sugar production has been reduced over the last two years due to a reduction in labor supply to the industry, mechanical problems in the factories, including the newly built Skeldon factory, and irregular weather patterns. Transformation of the industry has already begun and efforts to advance the process will continue in 2011. Greater reliance will be placed on the expansion of acreage through higher participation by private cane farmers to increase cane availability, as well as the introduction of mechanical harvesters, cane loaders and haulage units. Repairs are being undertaken to correct for mechanical defects and the Skeldon factory is expected to function at full capacity by the beginning of the second crop this year. 
18. In respect of the other sectors, additional investments are being made to expand production and benefit from world demand and more favorable prices, especially for rice, bauxite, gold and non-traditional exports. To sustain economic expansion substantial investments are being made in human and physical infrastructure. To improve the business environment, by reducing the cost and time of doing business, the authorities will advance the implementation of the Single Window Automated Processing System. Much emphasis is placed on enhancing security and justice and overall improvements in governance and the strengthening of democratic and cultural institutions.

19. The reduction of poverty is a major priority. Programs and policies to increase low income housing, medical facilities, access to electricity and water supplies are already taking place at a rapid pace. The authorities are moving ahead with the revised Poverty Reduction Strategy Paper, and with a Millennium Development Goal costing exercise prepared with technical assistance from donors. The authorities plan to put in place for adequate monitoring and evaluation mechanisms to support its implementation. Dialogue is continuing to take place with all stakeholders to maintain strong national consensus. 